OPEN@ACCESS

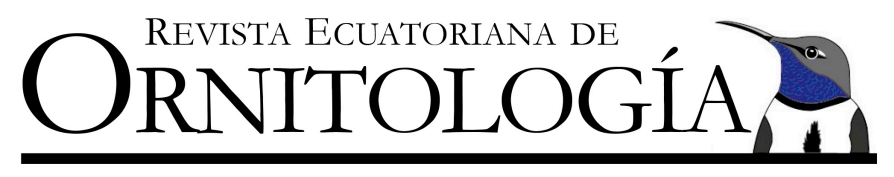

\title{
ARTÍCULO/ARTICLE
}

\section{Notes on the breeding biology of the Tumbesian avifauna in southwest Ecuador and northwest Peru}

\author{
Harold F. Greeney ${ }^{*}$, Fernando Angulo P. ${ }^{2}$, Robert C. Dobbs ${ }^{1}$, Segundo Crespo $^{2}$, Eliot T. Miller ${ }^{1,3}$, Daniel Cáceres ${ }^{4}$, \\ Rudolphe A. Gelis ${ }^{1}$, Briana Angulo ${ }^{2}$, Luis A. Salagaje M. ${ }^{1}$

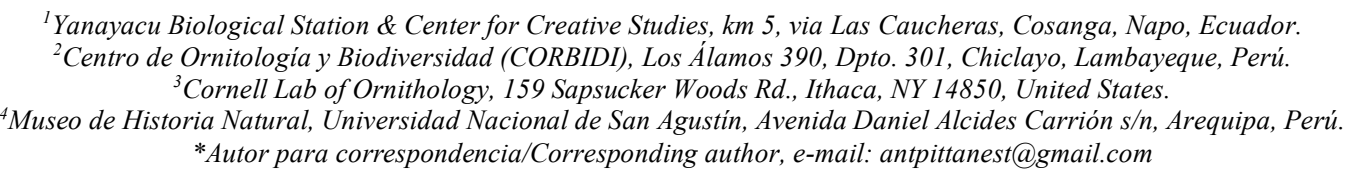 \\ Editado por/Edited by: Juan Freile \\ Recibido/Received: 6 Junio 2018 Aceptado/Accepted: 18 Septiembre 2019 \\ Publicado en línea/Published online: 22 Marzo 2020
}

\section{Notas sobre la biología reproductiva de la avifauna tumbesina en el suroeste de Ecuador y noroeste de Perú}

\section{Resumen}

Este artículo contribuye a la creciente cantidad de literatura sobre la biología reproductiva de las aves de Sudamérica. Provee 823 registros sobre la reproducción de 197 especies al interior de la región Tumbesina de Perú y Ecuador. En los casos posibles, incluimos notas sobre el comportamiento de los adultos, arquitectura del nido, huevos, pichones, polluelos y volantones. En general, nuestras observaciones apoyan los reportes previos sobre la naturaleza estacional de la reproducción de las aves de esta región.

Palabras clave: Biología reproductiva, bosque nublado, huevo, volantón, historia natural, nido, polluelo, pichón, bosque seco tropical.

\begin{abstract}
This paper contributes to the growing body of literature on the reproductive biology of South American birds by providing 823 records of reproduction for 197 species breeding within the Tumbesian biome of Peru and Ecuador. Where applicable, we include notes on adult behaviour, nest architecture, eggs, nestlings, and fledglings. In general, our observations support previous reports of the seasonal nature of avian reproduction in the region.
\end{abstract}

Keywords: Breeding biology, cloud forest, egg, fledgling, natural history, nest, nestling, tropical dry forest.

\section{INTRODUCTION}

The Tumbesian Endemic Bird Area of southwestern Ecuador and northwestern Peru contains the great majority of the remaining coastal tropical deciduous forest in South America and is among the most important and threatened of the currently recognized Endemic Bird Areas (EBAs; Cracraft, 1985; Stattersfield et al., 1998; BirdLife International, 2019). Most likely, less than $30 \%$ of the area remains forested, leaving a highly fragmented landscape of cropland surrounding small forest patches of native vegetation that are usually confined to areas with steeper slopes that are unproductive for agriculture and cattle (Best \& Kessler, 1995; PortilloQuintero \& Sánchez-Azofeifa, 2010; Hansen et al., 2013; BirdLife International, 2019). The Tumbesian region is one of the top five regions of the world with respect to the number of avian endemics, being home to more than 60 endemic species (Wege \& Long, 1995), at least 15 of which are considered at risk (BirdLife International, 2019). According to BirdLife International (2019), the avifauna in this region faces five primary threats: deforestation, understory degradation, hunting, wild animal trade, and species' small range sizes. The most severely endangered species are those which suffer a combination of these threats (Collar et al., 1992, 1994), and the conservation of remaining patches of habitat are of utmost importance (Parker \& Carr, 1992; Williams \& Tobias, 1994; Best \& Kessler, 1995; Parker et al., 1995; Espinosa et al., 2012; Tapia-Armijos et al., 2015). 
Whilst Freile et al. (2006) noted the relative paucity of information published on the birds of mainland Ecuador during the 20th century, recent years have seen a dramatic increase in the amount of published data on Neotropical birds (Freile et al., 2014). In particular, the reproductive biology of Ecuador's relatively understudied avifauna has received a good deal of attention in the past decade (e.g., Freile \& Chaves, 2004; Cisneros-Heredia, 2006; Greeney \& Nunnery, 2006; Greeney \& Gelis, 2007, 2008; Solano-Ugalde et al., 2007; Greeney et al., 2010, 2011; Solano-Ugalde, 2011; Carrasco et al., 2013). Although the aforementioned studies treat the avifauna of a large portion of Ecuador's diverse habitats, the Tumbesian region of Ecuador and northern Peru have been relatively neglected. Important recent contributions include life history information published by Freile et al. (2004) and Knowlton (2010), both building upon older studies from the region (Marchant, 1958, 1959, 1960a, 1960b; Best et al., 1992, 1993, 1996; Parker et al., 1995; Cook 1996). The remaining natural history information on the avifauna of the region is derived largely from a scattering of species-specific papers, most treating one or only a few species (Freile et al., 2003; Miller \& Greeney, 2008; Miller et al., 2007, 2010; Greeney, 2010; Greeney et al., 2012, 2013; Barrionuevo-García \& Montes-Torres, 2015; Greeney \& ValenciaHerverth, 2016). Importantly from a conservation point of view, however, many of these smaller works include threatened or near-threatened species, including: White-winged Guan Penelope albipennis (Angulo, 2004, 2008; Angulo \& Barrio, 2004; Cavero \& Angulo, 2011), Esmeraldas Woodstar Chaetocercus berlepschi (Ágreda, 2007; Juiña et al., 2010), El Oro Parakeet Pyrrhura orcesi (López-Lanús \& Lowen, 1999; Klauke et al., 2013), Watkins' Antpitta Grallaria watkinsi (Martin \& Dobbs, 2004; Greeney et al., 2009), Henna-hooded Foliage-gleaner Clibanornis erythrocephalus (Miller et al., 2012), Blackish-headed Spinetail Synallaxis tithys (Balchin, 1996; Crespo \& More, 2013), Gray-breasted Flycatcher Lathrotriccus griseipectus (Greeney, 2014), Ochraceous Attila Attila torridus (Greeney, 2006), Slaty Becard Pachyramphus spodiurus (Rheindt, 2008; Gelis et al., 2009), Peruvian Plantcutter Phytotoma raimondii (Flanagan et al., 2008, 2009; Rosina \& Romo, 2012; Nolazco \& Roper, 2013), and Pale-headed Brush-Finch Atlapetes pallidiceps (Oppel et al., 2003, 2004a, 2004b). With this contribution we provide 823 records of breeding activity for 197 species from the Tumbesian biome of Peru and Ecuador, including novel information on many of the aforementioned threatened species.

\section{METHODS}

All observations were made opportunistically during the course of other fieldwork in southwest Ecuador and northwest Peru between February 2000 and March 2018. Table 1 provides a list of the locations visited, their coordinates, and associated abbreviations. Because of the irregular and arbitrary dates that we were able to make observations, we emphasize that fact that our data may not be useful for some quantitative analyses. Most of the data we present is the result of brief observations and most nests were not monitored in detail. Where applicable, however, we include observations of behavior, nest architecture, eggs, and nest success. Table 2 provides a summary of all observations, including specific dates. For those species that were studied in more detail, or those whose data are worthy of additional discussion, we have expanded upon Table 2 with brief summaries of our observations in the following section. Species-level taxonomy follows Remsen et al. (2018), supplemented by the subspecific arrangement of del Hoyo \& Collar (2016).

\section{RESULTS AND DISCUSSION}

\section{Ecuadorian Trogon Trogon mesurus}

The nest and eggs of Trogon mesurus have only recently been described (Schulenberg \& Greeney, 2013), based on three nests studied at Jorupe. All three of the previously reported nests were unlined cavities within active arboreal termitaria. It is worth pointing out that two of the five additional nests we report (Table 2) were excavated within soft, rotting wood. Such variability in nesting substrates is also seen in other trogons (Skutch, 1999), but we provide the first documentation of such variation for T. mesurus.

\section{Watkins's Antpitta Grallaria watkinsi}

The breeding of this Tumbesian endemic antpitta is poorly studied (Greeney 2018). With only two nests described in the literature (Martin \& Dobbs, 2004; Greeney et al., 2009), published information on its biology is considered of high conservation priority (Freile \& Rodas 2008). We found two active nests in 2014 at Jorupe, one nearly-complete nest on 6 March, and a second with two $c$. 3-day-old nestlings on 4 April. The first nest was $2.6 \mathrm{~m}$ up in a tangle of small branches and vines within thick vegetation, and had the following measurements: external diameter $24 \mathrm{~cm}$, external height $10 \mathrm{~cm}$, inner diameter $10.5 \mathrm{~cm}$, inner depth $7 \mathrm{~cm}$. The second was $2.1 \mathrm{~m}$ up in tangled vegetation and measured: external diameter $22 \mathrm{~cm}$, external height $12 \mathrm{~cm}$, inner 
diameter $10 \mathrm{~cm}$, inner depth $6.5 \mathrm{~cm}$. These breeding records, but not the nest measurements, were presented in Greeney (2018).

Table 1: Summary of localities in southwest Ecuador and northwest Peru from whence breeding data were collected.

\begin{tabular}{|c|c|c|c|c|c|}
\hline Locality & $\begin{array}{c}\text { Department } \\
\text { (Per) } \\
\text { Province (Ecu) }\end{array}$ & $\begin{array}{l}\text { Provincia (Per) } \\
\text { Cantón (Ecu) }\end{array}$ & Code & Coordinates & $\begin{array}{c}\text { Elev. } \\
(\mathrm{m})\end{array}$ \\
\hline \multicolumn{6}{|l|}{ Ecuador } \\
\hline Cerro Blanco & Guayas & Guayaquil & EC1 & $\begin{array}{c}-2.1167,- \\
80.0833\end{array}$ & 300 \\
\hline Buenaventura & El Oro & Piñas & EC2 & $-3.65,-79.7667$ & 520 \\
\hline Jorupe & Loja & Macará & EC3 & $-4.3833,-79.95$ & 700 \\
\hline Manglares-Churute & Guayas & Guayaquil & EC4 & $-2.4667,-79.65$ & 50 \\
\hline Utuana & Loja & Sozoranga & EC5 & $-4.3667,-79.75$ & 2600 \\
\hline Vilcabamba & Loja & Loja & EC6 & $-4.25,-79.21667$ & 1575 \\
\hline El Empalme & Loja & El Empalme & EC7 & $\begin{array}{l}-4.11667,- \\
79.8333\end{array}$ & 760 \\
\hline Km 1047 Macará-Loja road & Loja & Celica & $\mathrm{EC} 8$ & $\begin{array}{c}-4.1833,- \\
79.8667\end{array}$ & 650 \\
\hline Km 1046 Macará-Loja road & Loja & Celica & EC9 & $-4.2,-79.8667$ & 660 \\
\hline Km 1048 Macará-Loja road & Loja & Celica & EC10 & $-4.2,-79.8667$ & 780 \\
\hline Km 45, Hwy 68, Celica-Macará & Loja & Celica & EC11 & $\begin{array}{c}-4.1333,- \\
79.91667\end{array}$ & 1600 \\
\hline Km 46, Hwy 68, Celica-Macará & Loja & Celica & $\mathrm{EC} 12$ & $\begin{array}{l}-4.1333,- \\
79.91667\end{array}$ & 1560 \\
\hline Km 49, Hwy 68, Celica-Macará & Loja & Celica & $\mathrm{EC} 13$ & $-4.15,-79.9$ & 1320 \\
\hline Celica & Loja & Celica & EC14 & $-4.1,-79.95$ & 2000 \\
\hline Isla de la Plata & Manabí & Puerto López & EC15 & $\begin{array}{c}-1.2667,- \\
81.0667\end{array}$ & 40 \\
\hline Km 1066 Macará-Loja road & Loja & Celica & EC16 & $-4.25,-79.8833$ & 1120 \\
\hline Yunguilla & Azuay & Santa Isabel & $\mathrm{EC} 17$ & $\begin{array}{l}-3.21667,- \\
79.2667\end{array}$ & 1750 \\
\hline Humedal La Segua & Manabí & Chone & EC18 & $\begin{array}{c}-0.7167,- \\
80.1833\end{array}$ & 100 \\
\hline Isla Santay & Guayas & Guayaquil & EC19 & $-2.05,-79.85$ & 30 \\
\hline Yangana-Tapichalaca Road & Loja & Loja & $\mathrm{EC} 20$ & $-4.4,-79.15$ & 2300 \\
\hline Reserva Río Ayampe & Manabí & Puerto López & $\mathrm{EC} 21$ & $\begin{array}{c}-1.6833,- \\
80.7833\end{array}$ & 100 \\
\hline Alamor & Loja & Puyango & EC22 & $\begin{array}{c}-4.01667,- \\
80.0167\end{array}$ & 1260 \\
\hline Yangana & Loja & Loja & EC23 & $\begin{array}{c}-4.3667,- \\
79.1667\end{array}$ & 1900 \\
\hline Lagunas Ecuasal & Santa Elena & Salinas & EC24 & $\begin{array}{l}-2.2461,- \\
80.9471\end{array}$ & 0 \\
\hline South of Guayaquil & Guayas & Guayaquil & EC25 & $-2.2,-79.75$ & 90 \\
\hline $\begin{array}{l}\text { Small pond, San Vicente-Chone } \\
\text { Road } \\
\text { Peru }\end{array}$ & Manabí & Chone & EC26 & $-0.65,-80.2667$ & 50 \\
\hline El Tutumo, Cuesta el Pitón & Tumbes & Zarumilla & TZA1 & $-3.75,-80.25$ & 360 \\
\hline Manglares de Tumbes & Tumbes & Zarumilla & TZA2 & $\begin{array}{c}-3.41667,- \\
80.2667\end{array}$ & 0 \\
\hline Mirador de Angostura & Tumbes & Tumbes & TTU1 & $-3.75,-80.35$ & 340 \\
\hline
\end{tabular}


Quebrada Angostura camino al

Caucho

Quebrada Angostura camino al

Caucho

El Caucho

Bocana Murciélagos

Quebrada Jurupe

Canoas

ACP Amotape

Punta Pico

Pueblo Blas-Lancones

Quebrada Gramadal, Coto de Caza

El Angolo

Cerro Pindo, Suyo

Cerro El Poto, Suyo

Bosque de Chonta

Quebrada Ancha

Punta Balcones

Paltashaco

Quebrada Caracucho

Villla Batanes, Chulucanas

Algodonal

Cerro Pilán, Chulucanas

Comunidad Ignacio Távara

Pasapera

Quebrada Tumberos,

Mangamanguilla, Salitral

Quebrada La Peña, Dotor

Quebrada El Garabo, Serrán

Laguna Santa Julia

Huabal, Canchaque

Chignia Alta, Huarmaca

La Pachinga, Tocto

Limón de Porculla

Quebrada Overal, Túpac Amaru

Manglares San Pedro de Vice

Laguna Napique

Bosque aledaño a la Laguna

Ramón

El Peñal, Rio Piura, Chutuque

Camino a la bocana de estuario de

Virrilá

Bosque Seco Aledaño al estuario de Virrilá
Tumbes

Tumbes

Tumbes

Tumbes

Tumbes

Tumbes

Tumbes

Piura

Piura

Piura

Piura

Piura

Piura

Piura

Piura

Piura

Piura

Piura

Piura

Piura

Piura

Piura

Piura

Piura

Piura

Piura

Piura

Piura

Piura

Piura

Piura

Piura

Piura

Piura

Piura
Tumbes

Tumbes

Tumbes

Tumbes

Tumbes

Contralmirante Villar

Contralmirante Villar

Contralmirante Villar

Sullana

Sullana

Ayabaca

Ayabaca

Ayabaca

Talara

Talara

Morropón

Morropón

Morropón

Morropón

Morropón

Morropón

Morropón

Morropón

Morropón

Piura

Huancabamba

Huancabamba

Huancabamba

Huancabamba

Huancabamba

Sechura

Sechura

Sechura

Sechura

Sechura

Sechura
$-3.7667,-80.3$

370

TTU3

$-3.7667,-80.333 \quad 110-$

$-3.81667,-$

80.2667

TTU5 -3.91667, -

80.1833

$-3.9667,-$

80.2667

$-3.91667,-80.9$

420

378

TTU6

477

TCO1

TCO2

$-3.65,-80.61667$

\section{0}

3

TCO3

$-3.75,-80.7833$

5

PSU1

$-4.25,-80.35 \quad 300-$

PSU2

$-4.41667,-$

550

80.7833

PAY1

$-4.5,-80.0$

PAY2

$-4.51667,-$

79.9833

PAY3 -4.633, -79.7667

PTA1

$-4.6,-81.033$

2260

PTA2

$-4.667,-$

81.31667

PMO1

$-5.1,-79.8833$

845

$-5.1333,-$ 79.91667

PMO3

$-5.1333,-80.1$

95

PMO4

$-5.1333,-79.9$

400

PMO5

$-5.15,-80.05$

$140-$

450

PMO6 -5.2333, $-80.333 \quad 210$

PMO7 $-5.2833,-79.85 \quad 340$

PMO8 -5.35, -79.71667 266-

PMO9 $\quad-5.45,-79.7833 \quad 340$

PPI01 $\quad-5.2,-80.65 \quad 30$

PHU1 $\quad-5.4,-79.65 \quad 726$

PHU2 $\quad-5.5833,-79.667 \quad 725$

PHU3 $-5.75,-79.6833 \quad 450$

PHU4 $\quad-5.8667,-\quad 1400$

79.51667

PHU5 $\quad-5.91667,-79.6 \quad 560$

PSE1 -5.5, $-80.8833 \quad 3$

PSE2 $\quad-5.51667,-80.7 \quad 7$

PSE3 $-5.55,-80.61667 \quad 10$

PSE4 -5.61667, $-80.65 \quad 4$

PSE5 $-5.81667,-\quad 5$

80.8667

PSE6 $\quad-5.85,-80.81667 \quad 3$ 


\begin{tabular}{llcccc} 
Caserío Huacrupe, Olmos & Lambayeque & Lambayeque & LLA1 & $-5.7833,-$ & 120 \\
Caserio Huacrupe a Abra de & Lambayeque & Lambayeque & LLA2 & $-5.8,-79.9333$ & 125 \\
Huacrupe, Olmos & & & & \\
Cerro Huacrupe, Olmos & Lambayeque & Lambayeque & LLA3 & $-5.81667,-79.95$ & 265 \\
Abra de Huacrupe, Olmos & Lambayeque & Lambayeque & LLA4 & $-5.81667,-79.95$ & 135 \\
Sarismusa & Lambayeque & Lambayeque & LLA5 & $-6.01667,-$ & 1100 \\
Bosque Palacios & Lambayeque & Lambayeque & LLA6 & $-6.05,-79.55$ & 800 \\
Cruz de Motupe & Lambayeque & Lambayeque & LLA7 & $-6.0833,-79.733$ & 85 \\
La Viña & Lambayeque & Lambayeque & LLA8 & $-6.3833,-79.75$ & 80 \\
Bosque de Pomac & Lambayeque & Ferreñafe & LFE1 & $-6.4666,-$ & 70 \\
Pítipo & & & & 79.76667 & 55 \\
Chiclayo & Lambayeque & Ferreñafe & LFE2 & $-6.5667,-$ & 59.7833 \\
Puerto Eten & Lambayeque & Chiclayo & LCH1 & $-6.7833,-$ & 30 \\
\hline & Lambayeque & Chiclayo & LCH2 & $-6.933,-79.866$ & 0 \\
\hline
\end{tabular}

\section{Line-cheeked Spinetail Cranioleuca antisiensis}

Most authors (Schulenberg et al., 2010; Dickinson \& Christidis, 2014) have treated Baron's Spinetail Cranioleuca baroni as separate from Line-cheeked Spinetail C. antisiensis (but see Koepcke, 1961, 1970; Meyer de Schauensee, 1970). Seeholzer \& Brumfield (2017), however, have suggested that the two are best considered conspecific. Regardless of their taxonomic status, however, the breeding biology of both taxa is poorly studied. The nest of Baron's Spinetail (subspecies zaratensis) was first described by Koepcke (1958, 1961), in rather general terms, as a large globular nest of moss with a side entrance. This description was slightly improved upon by Zyskowski \& Prum (1999), who correctly noted that the entrance was a downward-facing tunnel, providing the same generalized description for $C$. antisiensis and, technically, providing the first nest description for the latter species. The first detailed, quantified description of the nest of $C$. antisiensis (nominate antisiensis) should be credited to Cisneros-Heredia (2006). This last description, however, might be called into question, given that the location where the data were collected (Mashpi Protected Forest) is outside the species' recognized range (Dickinson \& Christidis 2014); Red-faced Spinetail C. erythrops is common at this locality. The following observations supplement this description and provide the first egg description for $C$. antisiensis. On 17 March 2005, at Yunguilla, we discovered a nest of nominate C. a. antisiensis containing two immaculate white eggs: $21.4 \times 16.4 \mathrm{~mm}, 2.96 \mathrm{~g}$, slight development; $21.2 \times 16.3 \mathrm{~mm}, 2.86 \mathrm{~g}$, addled. The nest was a bulky, teardrop-shaped nest of grasses, leaf strips, rootlets, and moss, hanging from tip of a low branch $2.4 \mathrm{~m}$ above the ground. The inner chamber was located within the bottom half of the structure, and was entered through short, downward-facing, tubular entrance. The internal chamber was lined with grass blades and leaf strips, while its lower portion (egg cup) was lined with fine grasses and lichens. Externally, the nest was $49 \mathrm{~cm}$ long (tall) and, at its widest point, was $33 \mathrm{~cm}$ wide. The entrance tunnel was $4 \mathrm{~cm}$ in diameter and $7.5 \mathrm{~cm}$ long, opening into a chamber $12 \mathrm{~cm}$ wide by $10 \mathrm{~cm}$ tall. Subsequently, at the same location, we examined a second nest, similar in form and composition to the first, attached at the end of a drooping branch, $4.5 \mathrm{~m}$ above the ground in a $15 \mathrm{~m}$-tall tree. Its measurements were: external length $51 \mathrm{~cm}$; maximum external width $35 \mathrm{~cm}$; entrance diameter $4.5 \mathrm{~cm}$; entrance tunnel length $9.5 \mathrm{~cm}$; internal diameter $11 \mathrm{~cm}$; internal height $10.5 \mathrm{~cm}$. On 12 March 2009 this nest contained two immaculate white eggs, both measuring $21.0 \times 16.0 \mathrm{~mm}$. In addition to these two closely examined nests, we found an active nest on 23 February 2000, at Celica, that was $c .3-4 \mathrm{~m}$ above the ground and $c .60 \mathrm{~cm}$ long $\times 40 \mathrm{~cm}$ wide externally. On 11 April 2006, at Utuana we observed an adult singing while carrying insects through the canopy. The adult dropped down and returned without food, repeating the process in same place a few minutes later. We were unable to locate a nest in the foliage visited by the adult, and we suggest it was feeding a stationary fledgling hidden amongst the leaves. Finally, on 12 February 2007, along the Yangana-Tapichalaca road, we observed a pair of adults scolding an Emerald Toucanet Aulacorhynchus prasinus that was consuming the contents of their nest through a large hole torn in the side. We were unable to determine if $A$. prasinus consumed nestlings or eggs. As an additional record of $C$. antisiensis breeding in Ecuador, on 18 October 2016 Paúl Molina (IBC-1281660; hbw.com/ibc/1281660) videotaped a pair of adults at an active nest near Cuenca, Azuay. The behaviour of the adults suggests they were feeding nestlings. 


\section{Long-tailed Mockingbird Mimus longicaudatus}

The nesting of this conspicuous member of western South America's arid coastal regions is fairly well documented (Taczanowski, 1884; Marchant, 1960a; Knowlton, 2010). On 7 March 2014, at Km 1046 on the Macará-Loja road, we examined a nest built $2.4 \mathrm{~m}$ up in a well-protected location amongst the branches of a spiny Acacia tree. The nest was a deep open bowl, loosely woven of long sticks externally (some spiny), and lined internally with light brown, think, flexible leaf petioles and mammal hairs. It measured: internal diameter $10 \mathrm{~cm}$, internal depth $7.5 \mathrm{~cm}$, external diameter $c .28$, external height $19 \mathrm{~cm}$. The nest contained two light blue eggs marked with spots and blotches of lavender and various shades of brown: $29.7 \times 20.2 \mathrm{~mm}, 6.23 \mathrm{~g}$, addled; $29.8 \times 20.0 \mathrm{~mm}, 6.26 \mathrm{~g}, c .1 / 3$ developed. Additional data in Table 2 .

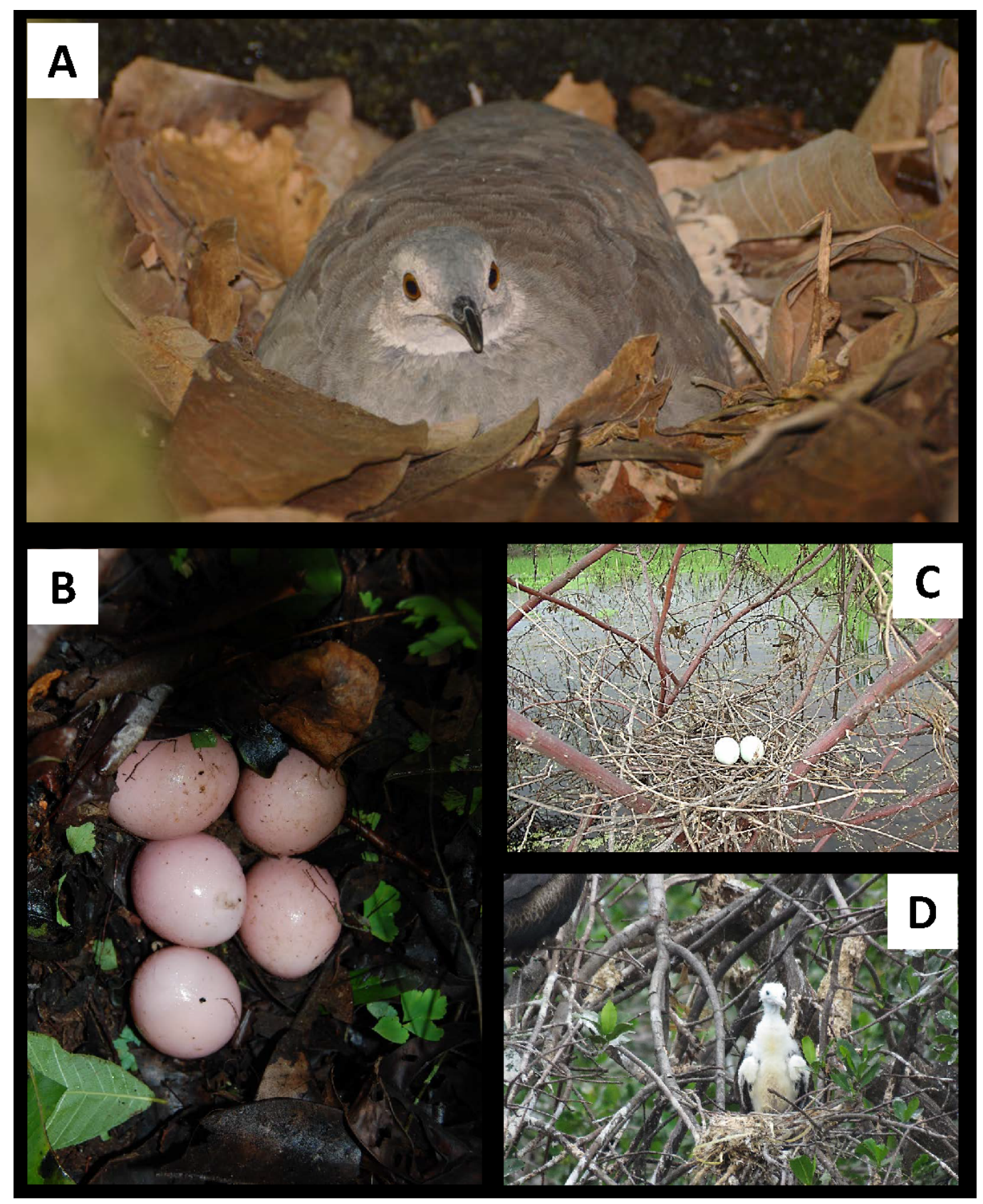

Figure 1: Nesting biology of birds of the Tumbesian Bioregion of Ecuador and Peru. For location details see Table 1. A) Adult Pale-browed Tinamou Crypturellus transfasciatus incubating four eggs, 25 March 2014, Jorupe (LASM); B) complete clutch of Pale-browed Tinamou, 14 February 2010, Jorupe (HFG); C) nest and eggs of Striated Heron Butorides striata 27 February 2006, east of Guayaquil (HFG); D) nestling of Magnificent Frigatebird Fregata magnificens, 26 January 2016, Manglares de Tumbes (FAP). 


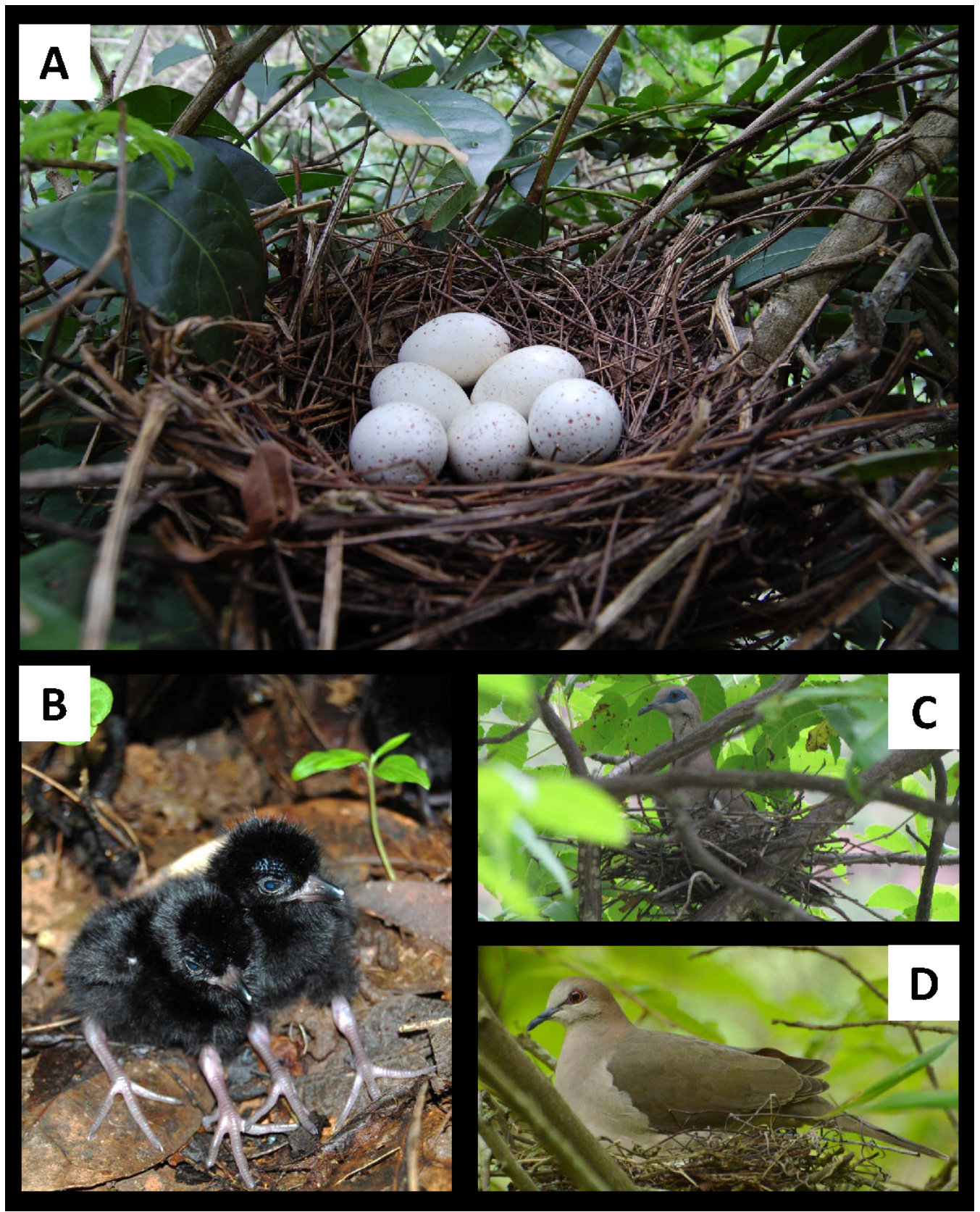

Figure 2: Nesting biology of birds of the Tumbesian Bioregion of Ecuador and Peru. For location details see Table 1. A) complete clutch of Rufous-necked Wood-Rail Aramides axillaris, 19 February 2010, Jorupe (HFG); B) newly hatched young of A. axillaris, 20 February 2010, Jorupe (HFG); C) adult West Peruvian Dove Zenaida meloda on its nest, 25 March 2009, Cerro Huacrupe (FAP); D) adult White-tipped Dove Leptotila verreauxi on its nest, 4 April 2014, Jorupe (LASM).

\section{CONCLUDING REMARKS}

The national systems of protected areas in both Peru and Ecuador offer protection to an important number of ecosystems and species within their respective countries (Fajardo et al., 2014; Espinosa et al., 2016; OrdóñezDelgado et al., 2016; Cuesta et al., 2017; Escribano-Ávila et al., 2017). Nevertheless, the high level of endemism in the Tumbesian region and the severe pressure facing its natural habitats combine to make its avifauna one of the most threatened in South America (BirdLife International, 2019) and one of the least protected ecosystems in Ecuador and Peru (Fajardo et al., 2014; Lessmann et al., 2014; Cuesta et al., 2017). While a fair number of publications, mostly locality-based, have focused on distribution and conservation of the Tumbesian avifauna (Wiedenfeld et al., 1985; Robbins \& Ridgely, 1990; Krabbe, 1992; Berg, 1994; Walker, 2002; Álava et al., 2007; Bonaccorso et al., 2007), and although the records presented here represent a significant addition to our knowledge of the reproductive biology of birds in the Tumbesian biome, the basic natural history of only a small 
percentage of its avifauna could be considered well-studied, and further research is urgently needed (Freile \& Santander, 2005; Freile et al., 2006; Freile \& Rodas, 2008).

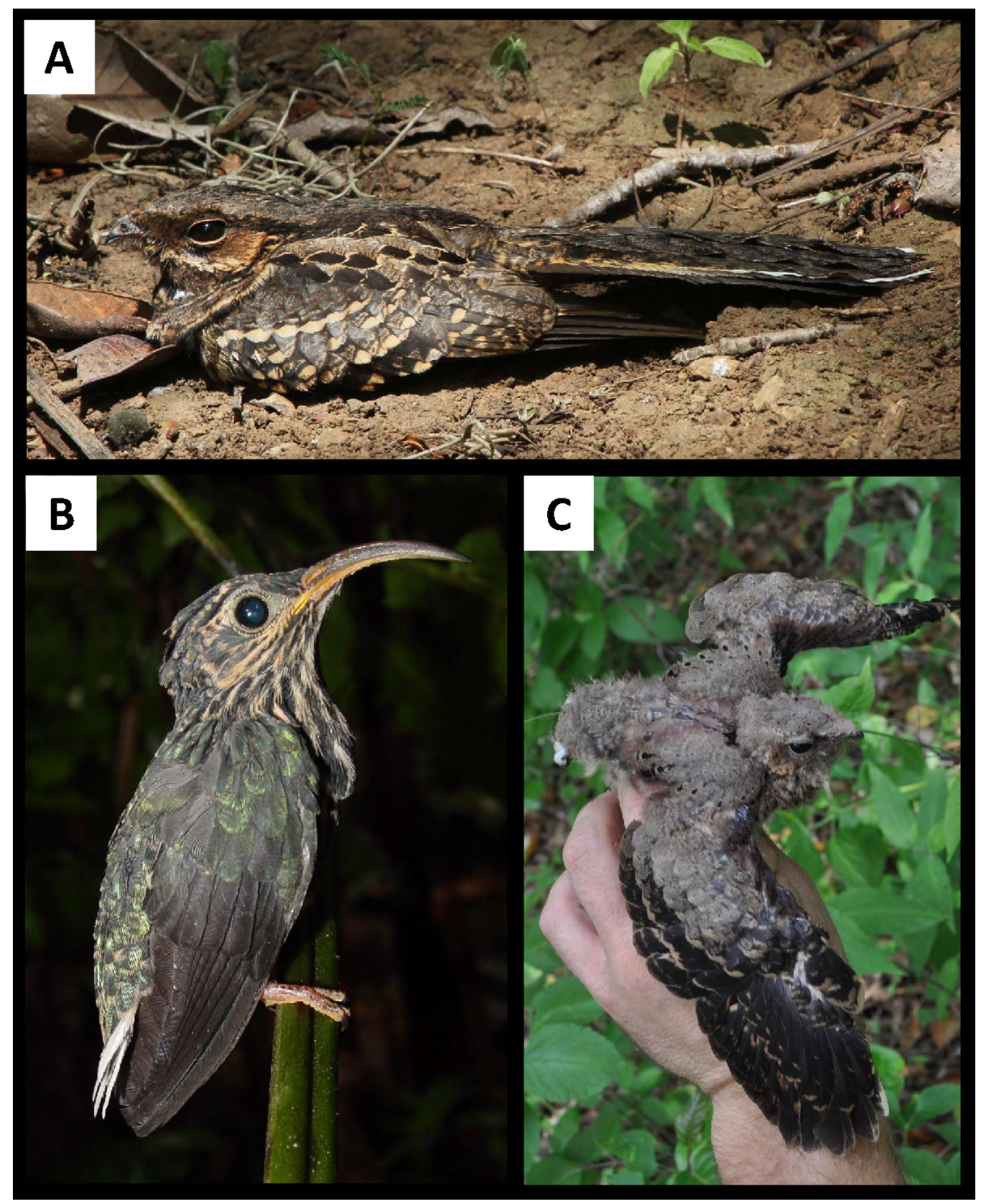

Figure 3: Nesting biology of birds of the Tumbesian Bioregion of Ecuador and Peru. For location details see Table 1. A) Adult Common Pauraque Nyctidromus albicollis incubating, 26 February 2014, Jorupe (HFG); B) fledgling White-tipped Sicklebill Eutoxeres aquila, 20 March 2004, Buenaventura (HFG); C) older nestling of N. albicollis, 18 January 2011, Cerro Blanco (HFG).

It comes as little surprise that our data support the previously recognized seasonality of reproductive activity in this seasonally arid region of South America (Marchant, 1959; Best et al..1993, 1996; Knowlton, 2010; Mischler, 2012; Barrionuevo-García \& Montes-Torres, 2015), with most records derived from the rainy season (January-March). Climatic conditions in the Tumbesian biome, however, vary from year to year, especially in relation to the El Niño Southern Oscillation, with additional local climatic variation due to the region's topography and heterogeneous habitat mosaic (Munday \& Munday, 1992; Best \& Kessler, 1995). Thus, as has been pointed out by previous authors (Robbins et al., 1994; Best et al., 1996; Freile et al., 2003), we should consider our understanding of avian reproductive seasonality in the region as highly preliminary. Its true nature, and how it varies across species, and through space and time, should be a research priority for future studies. 
The accumulation, dissemination, and analysis of quantitative natural history information, including reproductive seasonality, habitat use, and behavior, is critical to the formation and testing of sound hypotheses of ecological, evolutionary, taxonomic, and conservation significance (Morton, 1971; Ricklefs, 1977; Greene, 1994; Martin, 1996; Dayton, 2003; Greeney et al., 2008). It has not escaped our notice that similar such statements appear so frequently in the literature that the sentiment has taken on a mantra-like quality. Nevertheless, along with the authors of numerous papers lamenting the current academic devaluation of natural history research and the publication of descriptive results (Noss, 1996; Futuyma, 1998; Arnold, 2003; Dayton, 2003; Greene, 2005) we feel compelled to end with a similar message. We encourage others to gather and publish similar data to those presented here, for all regions of the world, but especially for the understudied and highly threatened Tumbesian biome.

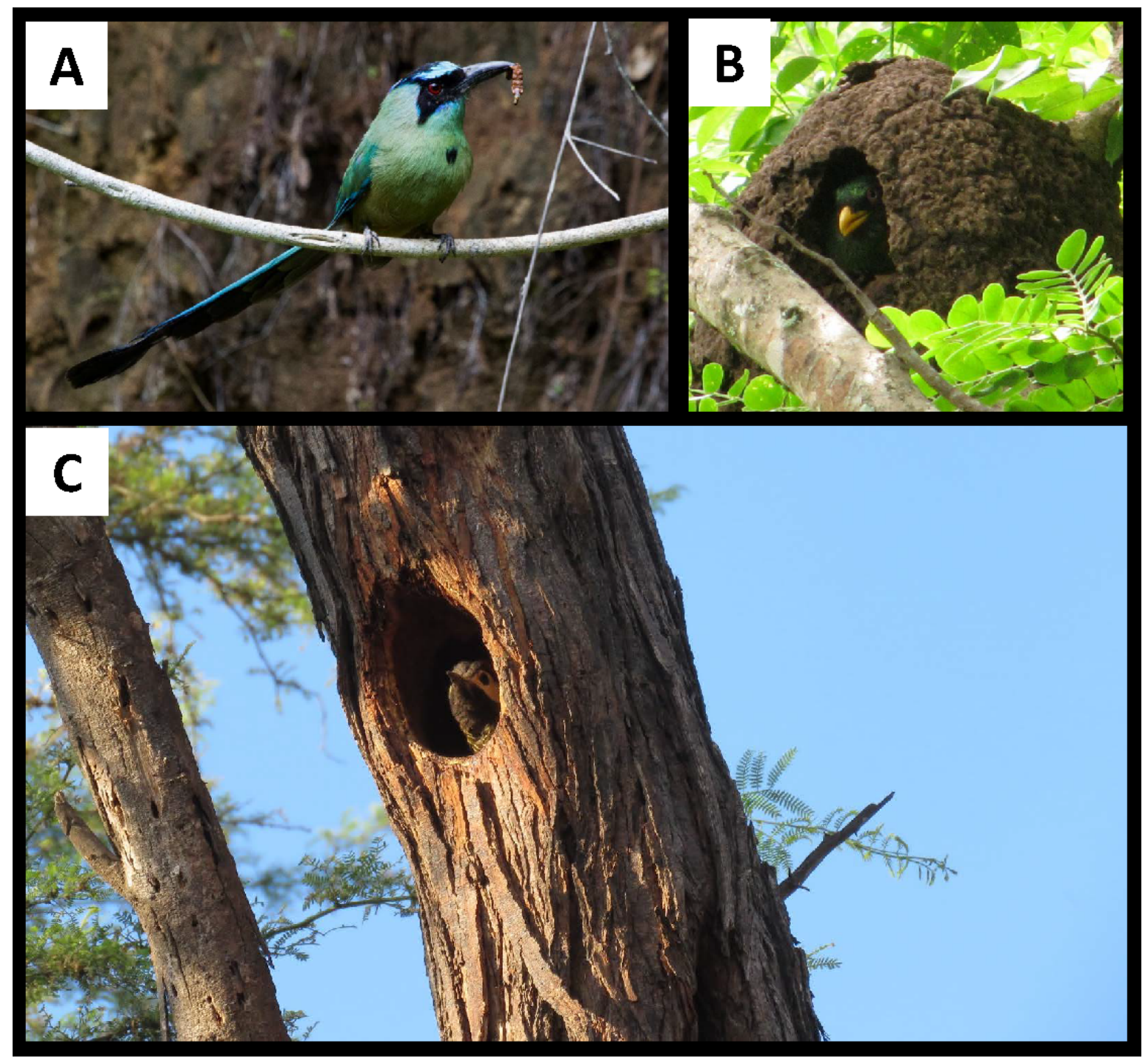

Figure 4: Nesting biology of birds of the Tumbesian Bioregion of Ecuador and Peru. For location details see Table 1. A) Adult Whooping Motmot Momotus subrufescens carrying food towards its nest, 7 March 2014, Jorupe (HFG); adult male Ecuadorian Trogon Trogon mesurus peering from its active nest, 6 March 2014, Jorupe (HFG); adult Golden-olive Woodpecker Colaptes rubiginosus peering from its nest cavity, 2 January 2016, Bosque de Pomac (FAP).

\section{ACKNOWLEDGEMENTS}

HFG and ETM thank the Jocotoco Foundation, Field Guides Inc., Matt Kaplan, and John V. Moore for supporting travel and fieldwork. FAP and SC want to thank BirdLife International, Nature and Culture International and PROFONANPE. FAP and DC thank Golondrinas de las Américas project for facilitating and supporting fieldwork. We thank Juan Freile and two anonymous reviewers for thoughtful comments and suggested revisions that improved earlier drafts of this manuscript. 


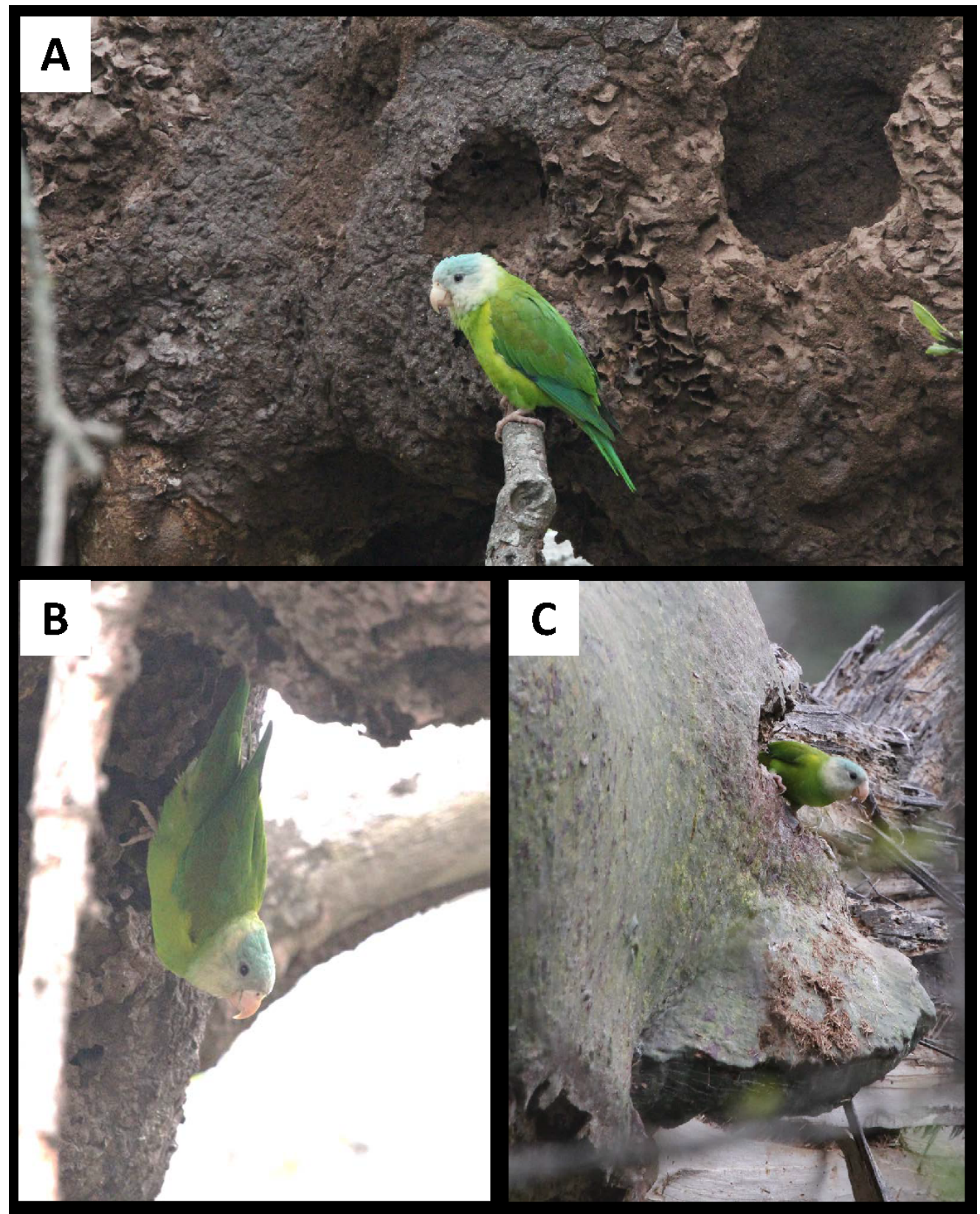

Figure 5: Nesting biology of birds of the Tumbesian Bioregion of Ecuador and Peru. For location details see Table 1. Adult Gray-cheeked Parakeets Brotogeris pyrrhoptera perched outside active nests at Jorupe. A) 28 February 2014; B-C) 27 February 2014 (HFG)

\section{REFERENCES}

Álava, J. J., Arosemena, X., Astudillo, E., Costantino, M., Peñafiel, M., \& Bohórquez, C. (2007). Occurrence, abundance and notes on some threatened Ecuadorian birds in the El Canclón Lagoon, Manglares, Churute Ecological Reserve. Ornitología Neotropical, 18(2), 223-232. URL: https://sora.unm.edu/node/133021

Ágreda, A. E. (2007). Feeding ecology and conservation of Esmeraldas Woodstar Chaetocercus berlepschi in the Chongón-Colonche Hills, western Ecuador. Cotinga, 27, 38-41. URL: www.neotropicalbirdclub.org/wpcontent/uploads/2015/05/C27-Agreda.pdf

Angulo, F. (2004). Dispersión, supervivencia y reproducción de la pava aliblanca Penelope albipennis Taczanowski 1877 (Cracidae) reintroducida a su hábitat natural en Perú. Ecología Aplicada, 3(1-2), 112-117. URL: http://www.scielo.org.pe/scielo.php?script=sci arttext\&pid=S1726-22162004000100015 
Angulo, F. (2008). Current status and conservation of wild and reintroduced White-winged Guan (Penelope albipennis) populations. Ornitología Neotropical, 19, S279-S286.

URL:

https://www.researchgate.net/publication/297717528 CURRENT_STATUS AND CONSERVATION_OF WILD AND REINTRODUCED WHITE-WINGED GUAN PENELOPE ALBIPENNIS POPULATIONS

Angulo, F., \& Barrio, J. (2004). Evaluation of a potential reintroduction site for the white-winged guan Penelope albipennis (Aves, Cracidae) in northern Peru. Oryx, 38(4), 448-451.

DOI: https://doi.org/10.1017/S0030605304000833

Arnold, S. J. (2003). Anniversary essay: Too much natural history, or too little? Animal Behaviour, 65(6), 10651068. DOI: https://doi.org/10.1006/anbe.2003.2143

Balchin, C. S. (1996). The nest of Blackish-headed Spinetail Synallaxis tithys. Bulletin of the British Ornithologists' Club, 116(2), 126-127.

URL: https://www.biodiversitylibrary.org/page/40029203\#page/450/mode/1up

Barrionuevo-García, R., \& Montes-Torres, M. D. (2015). Estrategia reproductiva de las aves de los manglares de San Pedro de Vice - Piura. Revista de Investigación para el Desarrollo Sustentable, 3(1), 18-32. URL: http://revistas.untrm.edu.pe/index.php/INDES/article/view/131

Berg, K. S. (1994). New and interesting records of birds from a dry forest reserve in south-west Ecuador. Cotinga, 2, 14-19. URL: https://www.neotropicalbirdclub.org/wp-content/uploads/2014/12/Cotinga-02-199414-19.pdf

Best, B. J., \& Kessler, M. (1995). Biodiversity and conservation in Tumbesian Ecuador and Peru. Cambridge, U.K.: BirdLife International.

Best, B. J., Broom, A. L., Checker, M., \& Thewlis, R. (1992). An ornithological survey of El Oro and western Loja province, south-west Ecuador, January-March 1991. In B. J. Best (Ed.), The threatened forests of southwest Ecuador (pp. 137-210). Leeds, U.K.: Biosphere Publications.

Best, B. J., Checker, M., Thewlis, R. M., Best, A. L., \& Duckworth, W. (1996). New bird breeding data from southwestern Ecuador. Ornitología Neotropical, 7(1), 69-73.

URL: http://www.ibiologia.unam.mx/pdf/links/neo/rev7/vol7 1/orni 7 1 69-73.pdf

Best, B. J., Clarke, C. T., Checker, M., Broom, A. L., Thewlis, R. M., Duckworth, W., \& McNab, A. (1993). Distributional records, natural history notes and conservation of some poorly known birds from southwestern Ecuador and northwestern Peru. Bulletin of the British Ornithologists' Club, 113(2), 234-255. URL: https://www.biodiversitylibrary.org/page/40028217\#page/120/mode/1up

BirdLife International (2019, 10 May) Endemic Bird Areas factsheet: Tumbesian region. URL: http://datazone.birdlife.org/eba/factsheet/47

Bonaccorso, E., Santander, T., Freile, J. F., Tinoco, B., \& Rodas, F. (2007). Avifauna and conservation of the Cerro Negro-Cazaderos area, Tumbesian Ecuador. Cotinga, 27, 61-66.

URL: http://www.neotropicalbirdclub.org/wp-content/uploads/2015/05/C27-Bonaccorso.pdf

Carrasco, L., Berg, K. S., Litz, J., Cook, A., \& Karubian, J. (2013). Avifauna of the Mache Chindul

Ecological Reserve, northwest Ecuador. Ornitología Neotropical, 24(3), 321-334. URL:

https://sora.unm.edu/node/133378

Cavero, T., \& Angulo, F. (2011). Health of the Critically Endangered white-winged guan Penelope albipennis and implications for its reintroduction and conservation in Peru. International Journal of Galliformes Conservation, 2, 43-53. 
Cisneros-Heredia, D. F. (2006). Notes on breeding, behaviour and distribution of some birds in Ecuador. Bulletin of the British Ornithologists' Club, 126(2), 153-164.

URL: https://www.biodiversitylibrary.org/item/127046\#page/75/mode/1up

Collar, N. J., Crosby, M. J., \& Stattersfield, A. J. (1994). Birds to watch 2: The world list of threatened birds. Cambridge, U.K.: BirdLife International.

Collar, N. J., Gonzaga, L. P., Krabbe, N., Madroño-Nieto, A., Naranjo, L. G., Parker, T. A., \& Wege, D. C. (1992). Threatened birds of the Americas: the ICBP/IUCN red data book, third edition, part 2. Washington DC: Smithsonian Institution Press \& International Council for Bird Preservation.

Cook, A. G. (1996). Avifauna of North-western Peru Biosphere Reserve and its environs. Bird Conservation International, 6(2), 139-165. DOI: https://doi.org/10.1017/S0959270900003038

Cracraft, J. (1985). Historical biogeography and patterns of differentiation within the South American avifauna: areas of endemism. Ornithological Monographs, 36, 49-84. URL: https://www.jstor.org/stable/40168278

Crespo, S., \& More, A. (2013). Distribución y estado de conservación del Cola-Espina de Cabeza Negruzca Synallaxis tithys en el noroeste de Perú. Cotinga, 35, 37-42. URL: www.neotropicalbirdclub.org/wpcontent/uploads/2015/03/C35-Crespo-More.pdf

Cuesta, F., Peralvo, M., Merino-Viteri, A., Bustamante, M., Baquero, F., Freile, J. F., Muriel, P., TorresCarvajal, O. (2017). Priority areas for biodiversity conservation in mainland Ecuador. Neotropical Biodiversity, 3(1), 93-106. DOI: https://doi.org/10.1080/23766808.2017.1295705

Dayton, P. K. (2003). The importance of natural sciences to conservation. American Naturalist, 162(1), 1-13. DOI: https://doi.org/10.1086/376572

Dickinson, E. C., \& Christidis, L. (Eds.). (2014). The Howard and Moore complete checklist of the birds of the World. 4th Edition. Volume 2, Passerines. Eastbourne, U.K.: Aves Press.

Escribano-Avila, G., Cervera, L., Ordóñez-Delgado, L., Jara-Guerrero, A., Amador, L., Paladines, B., Briceño, J., Parés-Jiménez, V., Lizcano, D. J., Duncan, D. H., \& Espinosa, C. I. (2017). Biodiversity patterns and ecological processes in Neotropical dry forest: The need to connect and management for long-term conservation. Neotropical Biodiversity, 3(1), 107-116.

DOI: http://dx.doi.org/10.1080/23766808.2017.1298495

Espinosa, C. I., De La Cruz, M., Luzuriaga, A. L. \& Escudero, A. (2012). Bosques tropicales secos de la región Pacífico Ecuatorial: diversidad, estructura, funcionamiento e implicaciones para la conservación. Ecosistemas, 21(1-2), 167-179. URL: https://www.revistaecosistemas.net/index.php/ecosistemas/article/view/35

Espinosa, C. I., Jara-Guerrero, A., Cisneros, R., Sotomayor, J. D. \& Escribano-Ávila, G. (2016). Reserva Ecológica Arenillas ¿un refugio de diversidad biológica o una isla en extinción? Ecosistemas, 25(2), 5-12. DOI: https://doi.org/10.7818/ECOS.2016.25-2.02

Fajardo, J., Lessmann, J., Bonaccorso, E., Devenish, C., \& Muñoz, J. (2014). Combined use of systematic conservation planning, species distribution modelling, and connectivity analysis reveals severe conservation gaps in a megadiverse country (Peru). PLoS ONE, 9(12), e114367.

DOI: https://doi.org/10.1371/journal.pone.0114367

Flanagan, J. N. M., \& Millen, B. M. (2008). First nest and egg records of the Peruvian Plantcutter Phytotoma raimondii, by O. D. Boggs. Bulletin of the British Ornithologists' Club, 128(4), 271.

URL: https://www.biodiversitylibrary.org/page/45653875\#page/295/mode/1up

Flanagan, J. N. M., Engblom, G., Franke, I., Valqui, T., \& Angulo, F. (2009). Distribution of the Peruvian Plantcutter Phytotoma raimondii (Passeriformes: Cotingidae). Revista Peruana de Biología, 16(2), 175-182. URL: http://200.62.146.19/BVRevistas/biologia/v16n2/pdf/a08v16n2.pdf 
Freile, J. F., \& Chaves, J. A. (2004). Interesting distributional records and notes on the biology of bird species from a cloud forest reserve in north-west Ecuador. Bulletin of the British Ornithologists' Club, 124(1), 6-16. URL: https://www.biodiversitylibrary.org/page/40056023

Freile, J. F., \& Rodas, F. (2008). Conservación de aves en Ecuador: ¿cómo estamos y qué necesitamos hacer? Cotinga , 29, 48-55. URL: www.neotropicalbirdclub.org/wp-content/uploads/2017/08/C29-Freile-Rodas.pdf

Freile, J. F., \& Santander, T. (2005). Áreas importantes para la conservación de las aves en Ecuador. Quito, Ecuador: Aves \& Conservación (Corporación Ornitológica del Ecuador).

Freile, J. F., Bonaccorso, E., \& Santander, T. (2003). First nesting report of the West Peruvian Screech-Owl (Otus roboratus). Ornitología Neotropical, 14(1), 107-111. URL: https://sora.unm.edu/node/119504

Freile, J. F., Carrión, J. M., Prieto-Albuja, F., Suárez, L., \& Ortiz-Crespo, F. (2006). La ornitología en Ecuador: un análisis del estado actual del conocimiento y sugerencias para prioridades de investigación. Ornitología Neotropical, 17(2), 183-202. URL: https://sora.unm.edu/sites/default/files/journals/on/v017n02/p0183p0202.pdf

Freile, J. F., Greeney, H. F., \& Bonaccorso, E. (2014). Current Neotropical ornithology: Research progress 1996-2007. Condor: Ornithological Applications, 116(1), 84-96. DOI: https://doi.org/10.1650/CONDOR-12152-R1.1

Freile, J. F., Moreano V., M., Bonaccorso, E., Santander, T., \& Chaves, J. A. (2004). Notas sobre la historia natural, distribución y conservación de algunas especies de aves amenazadas del suroccidente de Ecuador. Cotinga, 21, 18-24. URL: https://www.neotropicalbirdclub.org/wp-content/uploads/2016/10/C21-Freile.pdf

Futuyma, D. J. (1998). Wherefore and whither the naturalist? American Naturalist, 151(1), 1-6. URL: https://www.jstor.org/stable/10.1086/286097

Gelis, R. A., Greeney, H. F., \& Miller, E. T. (2009). Further observations on nesting of Slaty Becard Pachyramphus spodiurus. Cotinga, 31, 70-71.

URL: www.neotropicalbirdclub.org/wp-content/uploads/2016/10/C31-Gelis-et-al.pdf

Greene, H. W. (1994). Systematics and natural history, foundations for understanding and conserving biodiversity. American Zoologist, 34(1), 48-56. DOI: https://doi.org/10.1093/icb/34.1.48

Greene, H. W. (2005). Organisms in nature as a central focus for biology. Trends in Ecology and Evolution, 20(1), 23-27. DOI: https://doi.org/10.1016/j.tree.2004.11.005

Greeney, H. F. (2006). The nest and eggs of the Ochraceous Attila Attila torridus in south-west Ecuador with notes on parental care. Cotinga, 25, 56-58.

URL: www.neotropicalbirdclub.org/wp-content/uploads/2016/12/C25-Greeney.pdf

Greeney, H. F. (2010). The nest, egg, and nesting success of Ecuadorian Thrush (Turdus maculirostris) in southwest Ecuador. Ornitología Colombiana, 10, 38-42.

URL: http://asociacioncolombianadeornitologia.org/wp-content/uploads/revista/oc10/Greeney.pdf

Greeney, H. F. (2014). Breeding biology of the Grey-breasted Flycatcher Lathrotriccus griseipectus in southwest Ecuador. Bulletin of the British Ornithologists' Club, 134(1), 14-18.

URL: https://boc-online.org/bulletins/downloads/BBOC1341-Greeney.pdf

Greeney, H. F. (2018). Antpittas and gnateaters. London, U.K.: Christopher Helm. 


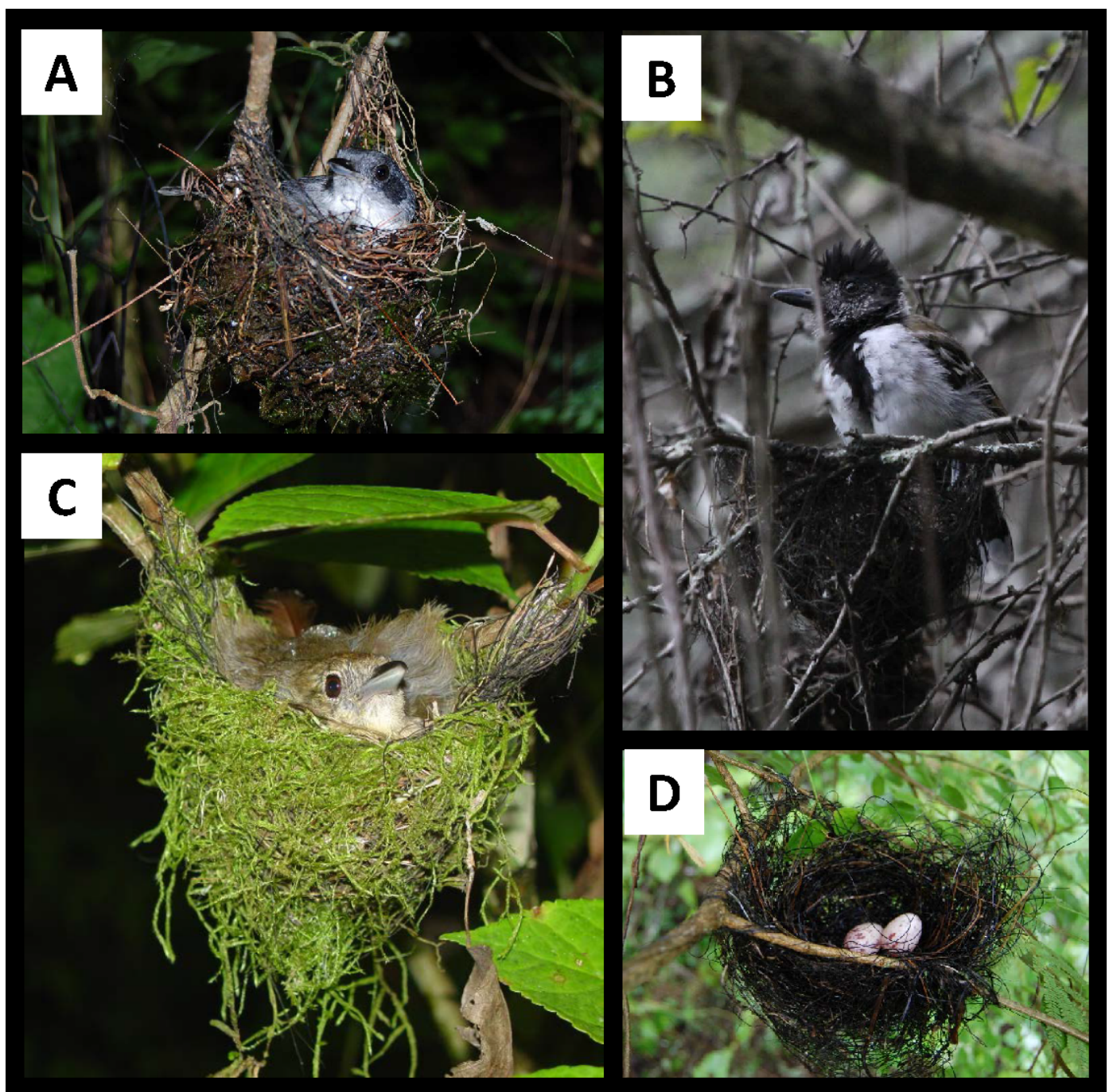

Figure 6: Nesting biology of birds of the Tumbesian Bioregion of Ecuador and Peru. For location details see Table 1. A) Adult male Plain Antvireo Dysithamnus mentalis incubating, 21 February 2010, Jorupe (HFG); B) adult male Collared Antshrike Thamnophilus bernardi perched on the rim of its nest, 2 March 2014, Jorupe (HFG); C) adult female Blackcrowned Antshrike Thamnophilus atrinucha, 11 February 2004, Buenaventura (HFG); D) T. bernardi nest with complete clutch, 22 February 2010, Jorupe (HFG).

Greeney, H. F., \& Gelis, R. A. (2007). Breeding records from the north-east Andean foothills of Ecuador. Bulletin of the British Ornithologists' Club, 127(3), 236-241.

URL: https://www.biodiversitylibrary.org/page/40877333\#page/70/mode/1up

Greeney, H. F., \& Gelis, R. A. (2008). Further breeding records from the Ecuadorian Amazonian lowlands. Cotinga, 29, 62-68. URL: www.neotropicalbirdclub.org/articles/29/Amazon.pdf

Greeney, H. F., \& Nunnery, T. (2006). Notes on the breeding of north-west Ecuadorian birds. Bulletin of the British Ornithologists' Club, 126(1), 38-45.

URL: https://www.biodiversitylibrary.org/page/40881746\#page/40/mode/1up

Greeney, H. F., \& Valencia-Herverth, R. (2016). Two "abnormal" clutches of Scaled Antpitta Grallaria guatimalensis. Cotinga, 38, 43-45. URL: www.neotropicalbirdclub.org/wp-content/uploads/2016/02/GreeneyValencia-Herverth.pdf

Greeney, H. F., Dobbs, R. C., Martin, P. R., \& Gelis, R. A. (2008). The breeding biology of Grallaria and Grallaricula antpittas. Journal of Field Ornithology, 79(2), 113-129. DOI: https://doi.org/10.1111/j.15579263.2008.00153.x 
Greeney, H. F., Juiña-J., M. E., Harris, J. B. C., Wickens, M. T., Winger, B., Gelis, R. A., Miller, E. T. \& Solano-Ugalde, A. (2010). Observations on the breeding biology of birds in south-east Ecuador. Bulletin of the British Ornithologists' Club, 130(1), 61-68.

URL: https://www.biodiversitylibrary.org/page/47499620\#page/65/mode/1up

Greeney, H. F., Lichter-Marck, I., \& Lichter-Marck, E. (2013). The nest, eggs, and nestlings of Grey-chinned Hermit Phaethornis griseogularis. Cotinga, 35, 112-113. URL: www.neotropicalbirdclub.org/wpcontent/uploads/2015/03/C35-Greeney-et-al.pdf

Greeney, H. F., Martin, P. R., Gelis, R. A., Solano-Ugalde, A., Bonier, F., Freeman, B. G., \& Miller, E. T. (2011). Notes on the breeding of high-Andean birds in northern Ecuador. Bulletin of the British Ornithologists' Club, 131(1), 24-31. URL: https://www.biodiversitylibrary.org/item/206985\#page/25/mode/1up

Greeney, H. F., Miller, E. T., \& Gelis, R. A. (2009). Observations on parental care and fledging of Watkins's Antpitta (Grallaria watkinsi). Ornitología Neotropical, 20(4), 619-622.

URL: https://sora.unm.edu/node/133137

Greeney, H. F., Solano-Ugalde, A., Juiña-J., M. E., \& Gelis, R. A. (2012). Observations on the breeding of Ochre-breasted Antpitta (Grallaricula flavirostris) in Ecuador. Ornitología Colombiana, 12, 4-9. URL: http://asociacioncolombianadeornitologia.org/wp-content/uploads/revista/oc12/GreeneyetalGFlavirostris.pdf

Hansen, M. C., Potapov, P. V., Moore, R., Hancher, M., Turubanova, S. A., Tyukavina, A., Thau, D., Stehman, S. V., Goetz, S. J., Loveland, T. R., Kommareddy, A., Egorov, A., Chini, L., Justice, C. O., \& Townshend, J. R. G. (2013). High-resolution global maps of 21 st-century forest cover change. Science, 342, 850-853. DOI: $10.1126 /$ science. 1244693

del Hoyo, J., \& Collar, N.J. (2016). HBW and BirdLife International illustrated checklist of birds of the world, vol. 2: Passerines. Barcelona, Spain: Lynx Edicions.

Juiña J., M. E., Harris, J. B. C., Greeney, H. F., \& Hickman, B. R. (2010). Descripción del nido y cuido parental de la estrellita esmeraldeña (Chaetocercus berlepschi) en el occidente del Ecuador. Ornitología Neotropical, 21(3), 313-322. URL: https://sora.unm.edu/node/133173

Klauke, N., Segelbacher, G., \& Schaefer, H. M. (2013). Reproductive success depends on the quality of helpers in the endangered, cooperative El Oro Parakeet (Pyrrhura orcesi). Molecular Ecology, 22(7), 2011-2027. DOI: $\underline{10.1111 / \mathrm{mec} .12219}$

Knowlton, J. L. (2010). Breeding records of birds from Tumbesian region of Ecuador. Ornitología Neotropical, 21(1), 109-129. URL: https://sora.unm.edu/sites/default/files/ON\%2021\%281\%29\%20109-129.pdf

Koepcke, M. (1958). Die Vögel des Waldes von Zárate. Bonner Zoologische Beiträge, 9, 130-193. URL: https://www.biodiversitylibrary.org/page/44733315\#page/152/mode/1up

Koepcke, M. (1961). Las razas geograficas de Cranioleuca antisiensis (Furnariidae, Aves), con la descripción de una nueva subespecie. Publicaciones del Museo de Historia Natural Zoología, 20, 1-17. URL: https://museohn.unmsm.edu.pe/docs/pub zoologia/Publicaciones\%20Zoología\%20Serie\%20A\%20N%2020. pdf

Koepcke, M. (1970). The birds of the department of Lima, Peru (Translation from Spanish). Wynnewood, PA: Livingston Publishing Company.

Krabbe, N. (1992). Notes on distribution and natural history of some poorly known Ecuadorean birds. Bulletin of the British Ornithologists' Club, 112(3), 169-174.

URL: https://www.biodiversitylibrary.org/page/40027922\#page/473/mode/1up 
Lessmann, J., Muñoz, J., \& Bonaccorso, E. (2014). Maximizing species conservation in continental Ecuador: a case of systematic conservation planning for biodiverse regions. Ecology and Evolution, 4(12), 2410-2422. DOI: $10.1002 /$ ece 3.1102

López-Lanús, B., \& Lowen, J. C. (1999). Observations of breeding activity in El Oro Parakeet Pyrrhura orcesi. Cotinga , 11, 46-47. URL: www.neotropicalbirdclub.org/articles/11/C11-EOPA.pdf

Marchant, S. (1958). The birds of the Santa Elena Peninsula, S. W. Ecuador. Ibis, 100(3), 349-387. DOI: https://doi.org/10.1111/j.1474-919X.1958.tb00404.X

Marchant, S. (1959). The breeding season in S. W. Ecuador. Ibis, 101(2), 137-152. DOI: https://doi.org/10.1111/j.1474-919X.1959.tb02370.x

Marchant, S. (1960a). The breeding of some S.W. Ecuadorian birds. Ibis, 102(3), 349-382. DOI: https://doi.org/10.1111/j.1474-919X.1960.tb08415.x

Marchant, S. (1960b). The breeding of some S.W. Ecuadorian birds (cont.). Ibis, 102(4), 584-599. DOI: https://doi.org/10.1111/j.1474-919X.1960.tb07134.X

Martin, P. R., \& Dobbs, R. C. (2004). Description of the nest, egg and nestling of Watkin's Antpitta Grallaria watkinsi. Cotinga, 21, 35-37. URL: www.neotropicalbirdclub.org/wp-content/uploads/2016/10/C21Martin.pdf

Martin, T. E. (1996). Life history evolution in tropical and south temperate birds: What do we really know? Journal of Avian Biology, 27(4), 263-272. DOI: 10.2307/3677257

Meyer de Schauensee, R. (1970). A guide to the birds of South America. Wynnewood, PA: Livingston Publishing Company.

Miller, E. T., \& Greeney, H. F. (2008). Clarifying the nest architecture of the Silvicultrix clade of Ochthoeca chat-tyrants (Tyrannidae). Ornitología Neotropical, 19(4), 361-370. URL:

https://sora.unm.edu/sites/default/files/ON (19) 361-370.pdf

Miller, E. T., Greeney, H. F., Lichter-Marck, I., Lichter-Marck, E., \& Cabrera, L. F. (2012). The breeding of the Henna-hooded Foliage-gleaner, Hylocryptus erythrocephalus, with notes on conservation concerns. Ornitología Neotropical, 23(4), 517-527.

URL: https://sora.unm.edu/sites/default/files/ON\%2023\%284\%29\%20517-527.pdf

Miller, E. T., Greeney, H. F., \& Valdez, U. (2010). Breeding behavior of the Laughing Falcon (Herpetotheres cachinnans) in southwestern Ecuador and northwestern Peru. Ornitología Colombiana, 10, 43-50. URL: http://asociacioncolombianadeornitologia.org/wp-content/uploads/revista/oc10/Miller.pdf

Miller, E. T., Greeney, H. F., Zyskowski, K., \& Gelis, R. A. (2007). First description of the nest and eggs of the Gray-and-gold Warbler (Basileuterus fraseri). Ornitología Neotropical, 18(4), 617-621. URL: https://sora.unm.edu/sites/default/files/ON\%20\%2818\%29\%20617-622.pdf

Mischler, T. C. (2012). Status, abundance, seasonality, breeding evidence and an updated list of the birds of Cerro Blanco, Guayaquil, Ecuador. Cotinga, 34, 60-72.

URL: https://www.neotropicalbirdclub.org/wp-content/uploads/2018/06/C34-Mischler.pdf

Morton, E. S. (1971). Nest predation affecting the breeding season of the Clay-colored Robin, a tropical song bird. Science, 171, 920-921. DOI: https://doi.org/10.1126/science.171.3974.920 


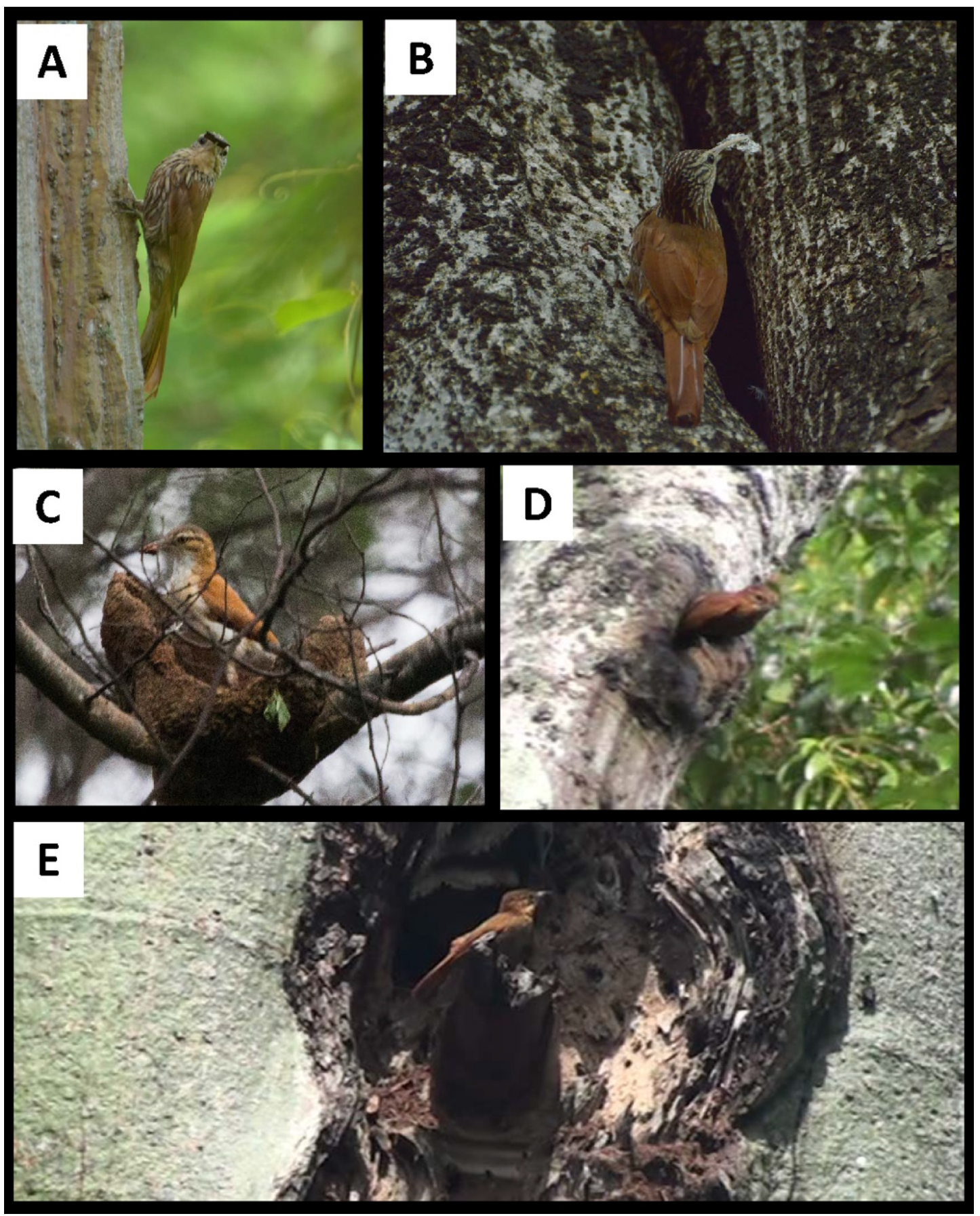

Figure 7: Nesting biology of birds of the Tumbesian Bioregion of Ecuador and Peru. For location details see Table 1. AB) adult Streak-headed Woodcreepers Lepidocolaptes souleyetii carrying bark chips to their nests at Jorupe on 2 April 2014 and 26 March 2014 (LASM); C) adult Pale-legged Hornero Furnarius leucopus building its nest, 6 March 2014, Jorupe (HFG); D-E) adult Rufous-necked Foliage-gleaners Syndactyla ruficollis near their nest entrances at Jorupe, 5 March and 21 February 2010 (HFG).

Munday, M., \& Munday, G. (1992). The climate of south-west Ecuador. In B. J. Best (Ed.), The threatened forests of south-west Ecuador (pp. 7-78). Leeds, U.K.: Biosphere Publications.

Nolazco, S., \& Roper, J. J. (2013). Descriptive note of reproduction in the Peruvian Plantcutter (Phytotoma raimondii) in the Bosque de Pomac Historical Sanctuary, Lambayeque, Perú. Boletín de la Unión de Ornitólogos del Perú (UNOP), 8, 6-13. URL: https://boletinunop.weebly.com/volumen-8-nordm-2--2013.html 
Noss, R. F. (1996). The naturalists are dying off. Conservation Biology, 10(1), 1-3. DOI: https://doi.org/10.1046/j.1523-1739.1996.10010001.x

Oppel, S., Schaefer, H. M., \& Schmidt, V. (2003). Description of the nest, eggs, and breeding behavior of the endangered Pale-headed Brush-Finch (Atlapetes pallidiceps) in Ecuador. Wilson Bulletin, 115(4), 360-366. DOI: https://doi.org/10.1676/03-020

Oppel, S., Schaefer, H. M., Schmidt, V., \& Schroder, B. (2004a). Cowbird parasitism of Pale-headed Brushfinch Atlapetes pallidiceps: implications for conservation and management. Bird Conservation International, 14(2), 63-75. DOI: https://doi.org/10.1017/S0959270904000103

Oppel, S., Schaefer, H. M., Schmidt, V., \& Schroder, B. (2004b). Habitat selection by the Pale-headed BrushFinch (Atlapetes pallidiceps) in southern Ecuador: implications for conservation. Biological Conservation, 118(1), 33-40. DOI: https://doi.org/10.1016/j.biocon.2003.07.006

Ordóñez-Delgado, L., Tomás, G., Armijos-Ojeda, D., Jara-Guerrero, A., Cisneros, R., \& Espinosa, C. I. (2016). Nuevos aportes al conocimiento de avifauna en la región Tumbesina; implicaciones para la conservación de la Reserva de Biosfera del Bosque Seco, Zapotillo, Ecuador. Ecosistemas, 25(2), 13-23. DOI: https://doi.org/10.7818/ECOS.2016.25-2.03

Parker, T. A., III, \& Carr, J. L. (1992). Status of forest remnants in the Cordillera de la Costa and adjacent areas of southwestern Ecuador. RAP Working Papers, 2, 1-172.

URL: https://bibdigital.epn.edu.ec/bitstream/15000/4788/1/RAP02 Cordillera Costa Ecuador Oct-1992.pdf

Parker, T. A., III, Schulenberg, T. S., Kessler, M., \& Wust, W. (1995). Natural history and conservation of the endemic avifauna of north-west Peru. Bird Conservation International, 5(2-3), 201-232. DOI: https://doi.org/10.1017/S0959270900001015

Portillo-Quintero, C. A. \& Sánchez-Azofeifa, G. A. (2010). Extent and conservation of tropical dry forests in the Americas. Biological Conservation, 143(1), 144-155. DOI: https://doi.org/10.1016/j.biocon.2009.09.020

Remsen, J. V., Jr., Areta, J. I., Cadena, C. D., Claramunt, S., Jaramillo, A., Pacheco, J. F., Pérez-Emán, J., Robbins, M. B., Stiles, F. G., Stotz, D. F. \& Zimmer, K. J. (2018, 30 January). A classification of the bird species of South America. American Ornithologists' Union.

URL: http://www.museum.lsu.edu/ Remsen/SACCBaseline.html.

Rheindt, F. E. (2008). Descripción preliminar del nido de Pachyramphus spodiurus, especie amenazada. Cotinga, 29, 162-163. URL: www.neotropicalbirdclub.org/articles/29/Nido.pdf

Ricklefs, R. E. (1977). On the evolution of reproductive strategies in birds: reproductive effort. American Naturalist, 111(979), 453-478. DOI: https://doi.org/10.1086/283179

Robbins, M. B., \& Ridgely, R. S. (1990). The avifauna of an upper tropical cloud forest in southwestern Ecuador. Proceedings of the Academy of Natural Sciences of Philadelphia, 142, 59-71. URL: https://www.jstor.org/stable/4064971

Robbins, M. B., Ridgely, R. S., \& Cardiff, S. W. (1994). Voice, plumage and natural history of Anthony's Nightjar (Caprimulgus anthonyi). Condor, 96(2), 224-228. DOI: 10.2307/1369085

Rosina, M., \& Romo, M. (2012). Reproducción y alimentación de Phytotoma raimondii, cortarrama peruana en El Gramadal, Ancash. Revista Peruana de Biología, 19(2), 167-173.

URL: www.scielo.org.pe/pdf/rpb/v19n2/a07v19n2.pdf

Schulenberg, T. S., \& Greeney, H. F. (2013). Ecuadorian Trogon (Trogon mesurus). In T. S. Schulenberg (Ed.), Neotropical Birds Online. Ithaca, NY: Cornell Lab of Ornithology.

URL: https://neotropical.birds.cornell.edu/Species-Account/nb/species/bkttro2/overview 
Schulenberg, T. S., Stotz, D. F., Lane, D. F., O’Neill, J. P., \& Parker, T. A., III. (2010). Birds of Peru: Revised and updated edition. Princeton, NJ: Princeton University Press.

Seeholzer, G. F., \& Brumfield, R. T. (2017). Isolation by distance, not incipient ecological speciation, explains genetic differentiation in an Andean songbird (Aves: Furnariidae: Cranioleuca antisiensis, Line-cheeked Spinetail) despite near threefold body size change across an environmental gradient. Molecular Ecology, 27(1), 279-296. DOI: https://doi.org/10.1111/mec.14429

Skutch, A. F. (1999). Trogons, laughing falcons, and other neotropical birds. College Station, TX: Texas A \& M University Press.

Solano-Ugalde, A. (2011). Notes on the distribution and natural history of bird species in the Chocó bioregion of Ecuador. Bulletin of the British Ornithologists' Club, 131(4), 149-255. URL: https://www.biodiversitylibrary.org/page/50795731\#page/27/mode/1up

Solano-Ugalde, A., Arcos-Torres, A., \& Greeney, H. F. (2007). Additional breeding records for selected avian species in northwest Ecuador. Boletín de la Sociedad Antioqueña de Ornitología, 17, 17-25. URL: http://www.sao.org.co/publicaciones/boletinsao/AP2 XVII 1 2007.pdf

Stattersfield, A. J., Crosby, M. J., Long, A. J., \& Wege, D. C. (1998). Endemic bird areas of the World. Priorities for biodiversity conservation. Cambridge, U.K.: BirdLife International.

Taczanowski, L. (1884). Ornithologie du Pérou (Vol. 1). Berlin, Germany: R. Friedländer \& Sohn.

Tapia-Armijos, M. F., Homeier, J., Espinosa, C. I., Leuschner, C. \& De La Cruz, M. (2015). Deforestation and forest fragmentation in south Ecuador since the 1970s - Losing a hotspot of biodiversity. PLoS ONE, 10(9), e0133701. DOI: https://doi.org/10.1371/journal.pone.0133701

Walker, B. (2002). Observations from the Tumbes Reserved Zone, dpto. Tumbes, with notes on some new taxa for Peru and a checklist of the area. Cotinga, 18, 37-43. URL: www.neotropicalbirdclub.org/wpcontent/uploads/2016/05/Cotinga-18-2002-37-43.pdf

Wege, D. C., \& Long, A. J. (1995). Key areas for threatened birds in the Neotropics. Cambridge, U.K.: BirdLife International.

Wiedenfeld, D. A., Schulenberg, T. S., \& Robbins, M. B. (1985). Birds of a tropical deciduous forest in extreme northwestern Peru. Ornithological Monographs, 36, 305-315. URL: https://www.jstor.org/stable/i40004512

Williams, R. S. R., \& Tobias, J. A. (Eds.). (1994). The conservation of southern Ecuador's threatened avifauna. Final report of the Amaluza Projects, 1990-1991. Cambridge, U.K.: International Council for Bird Preservation.

Zyskowski, K., \& Prum, R. O. (1999). Phylogenetic analysis of the nest architecture of Neotropical ovenbirds (Furnariidae). Auk, 116(4), 891-911. DOI: https://doi.org/10.2307/4089670 


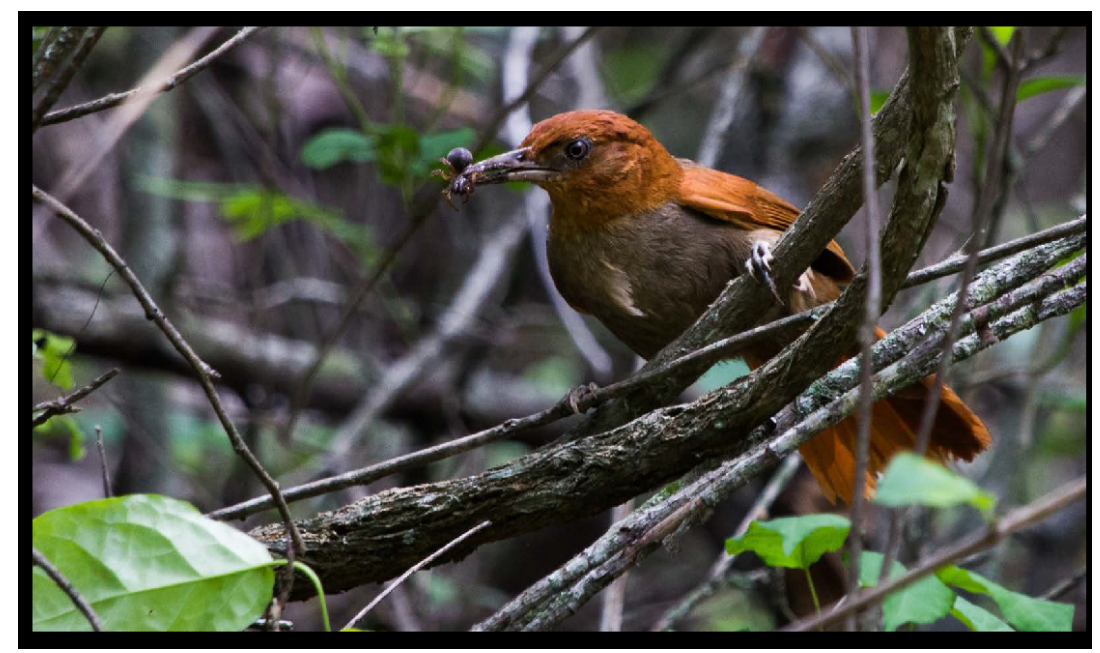

Figure 8: Nesting biology of birds of the Tumbesian Bioregion of Ecuador and Peru. For location details see Table 1. A) Adult Henna-hooded Foliage-gleaner Clibanornis erythrocephalus carrying a spider for its nestlings, 7 March 2014, Jorupe (HFG).
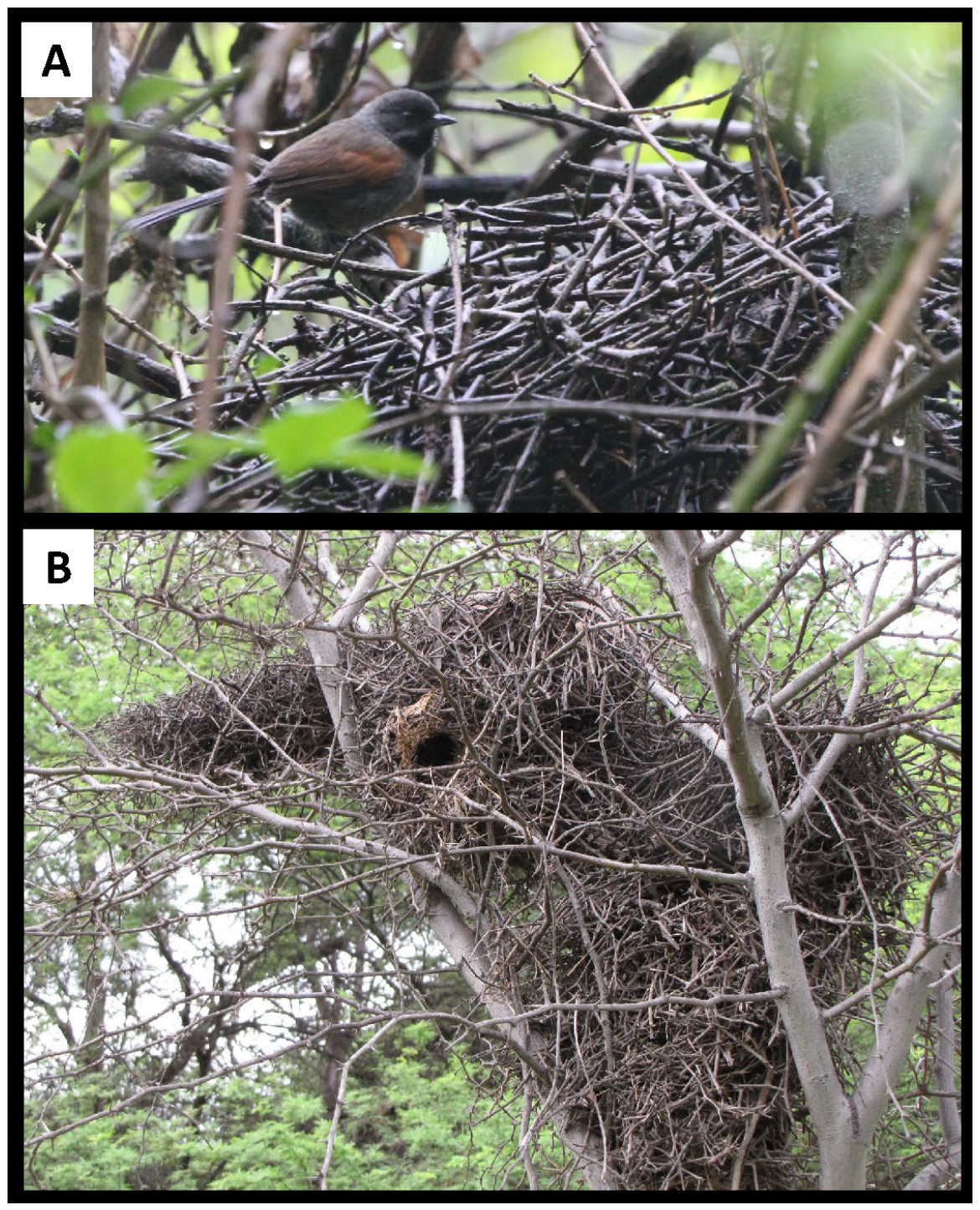

Figure 9: Nesting biology of birds of the Tumbesian Bioregion of Ecuador and Peru. For location details see Table 1. A) Adult Blackish-headed Spinetail Synallaxis tithys perched atop its nest, 1 March 2014, Jorupe (HFG); B) Nest of Necklaced Spinetail Synallaxis stictothorax, 24 March 2009, Abra de Huacrupe (FAP). 

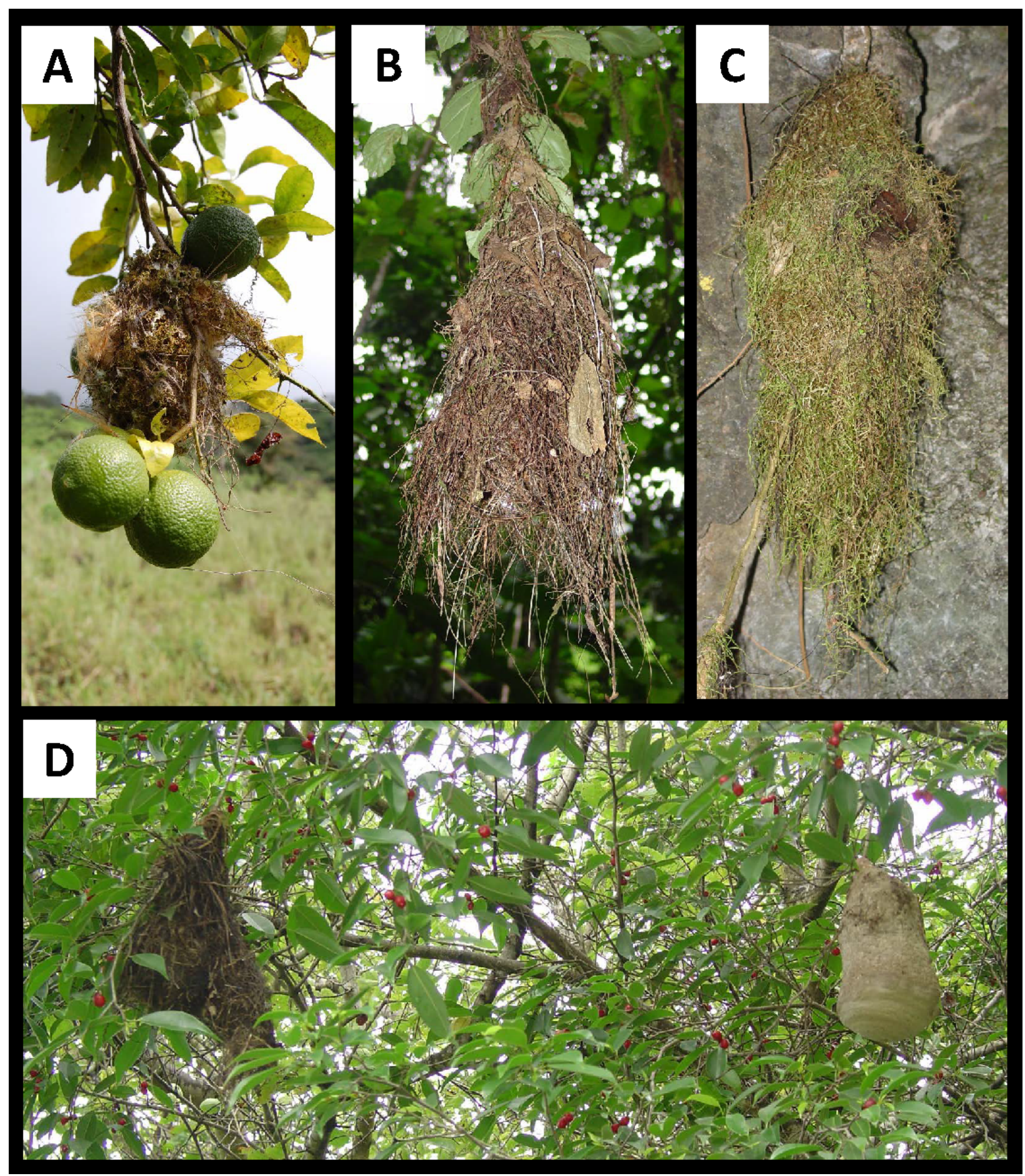

Figure 10: Nesting biology of birds of the Tumbesian Bioregion of Ecuador and Peru. For location details see Table 1. A) Nest of Southern Beardless-Tyrannulet Camptostoma obsoletum, 17 February 2010, Jorupe (HFG); B) Nest of Sulphurrumped Flycatcher Myiobius barbatus, 31 January 2004, Buenaventura (HFG); C) Nest of Ochre-bellied Flycatcher Mionectes oleagineus, 31 January 2004, Buenaventura (HFG); D) Nest of Yellow-olive Flycatcher Tolmomyias sulphurescens near an active wasp (Vespidae) nest, 24 February 2006, Jorupe (HFG). 


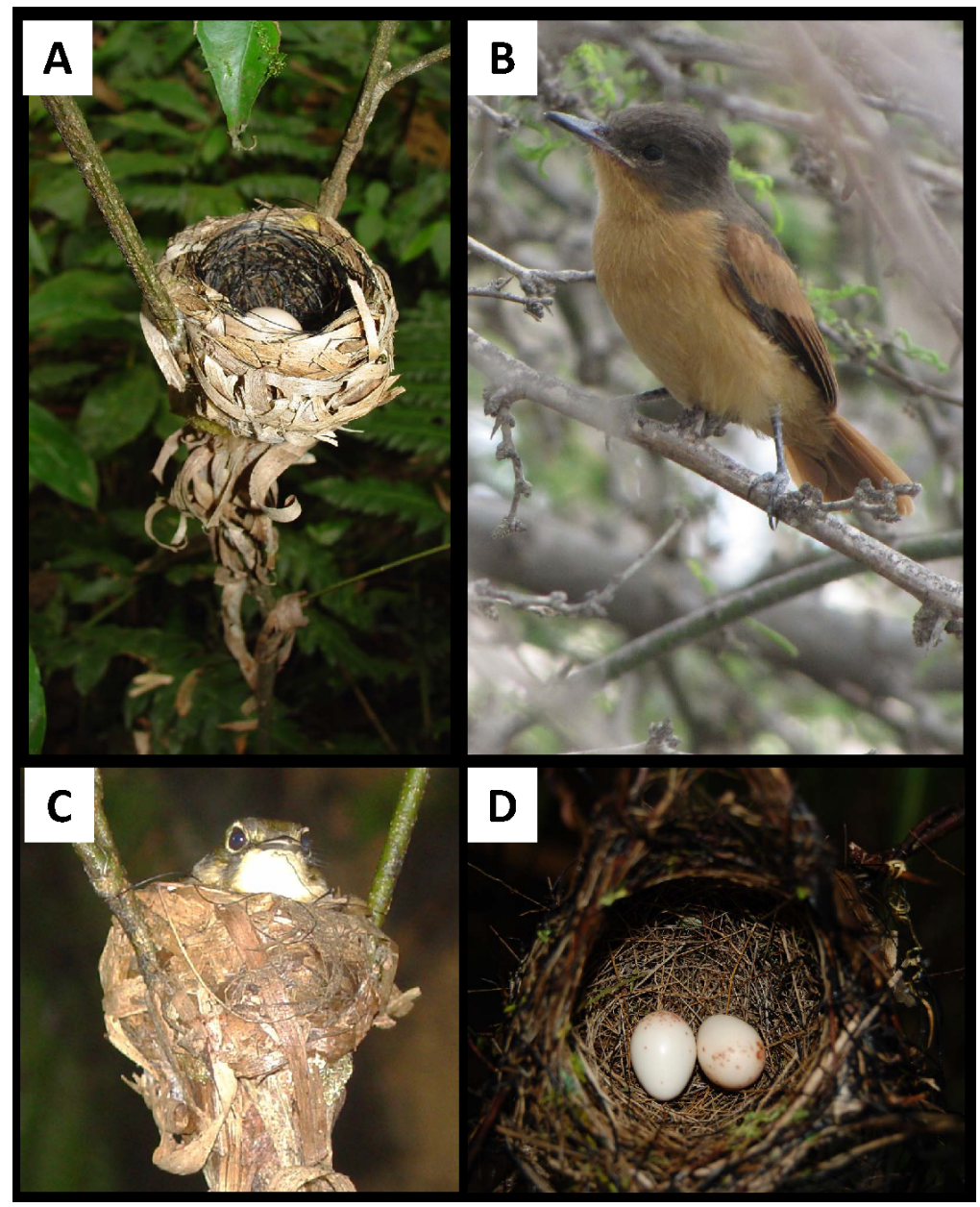

Figure 11: Nesting biology of birds of the Tumbesian Bioregion of Ecuador and Peru. For location details see Table 1. A) Nest and single-egg clutch of White-throated Spadebill Platyrinchus mystaceus, 1 February 2004, Buenaventura (HFG); B) Fledgling Rufous Flycatcher Myiarchus semirufus, 26 February 2009, Estuario de Virrila (FAP); C) Adult P. mystaceus on its nest, 12 February 2004, Buenaventura (HFG); D) Nest and complete clutch of Bran-colored Flycatcher Myiophobus fasciatus, 16 February 2010, Jorupe (HFG).

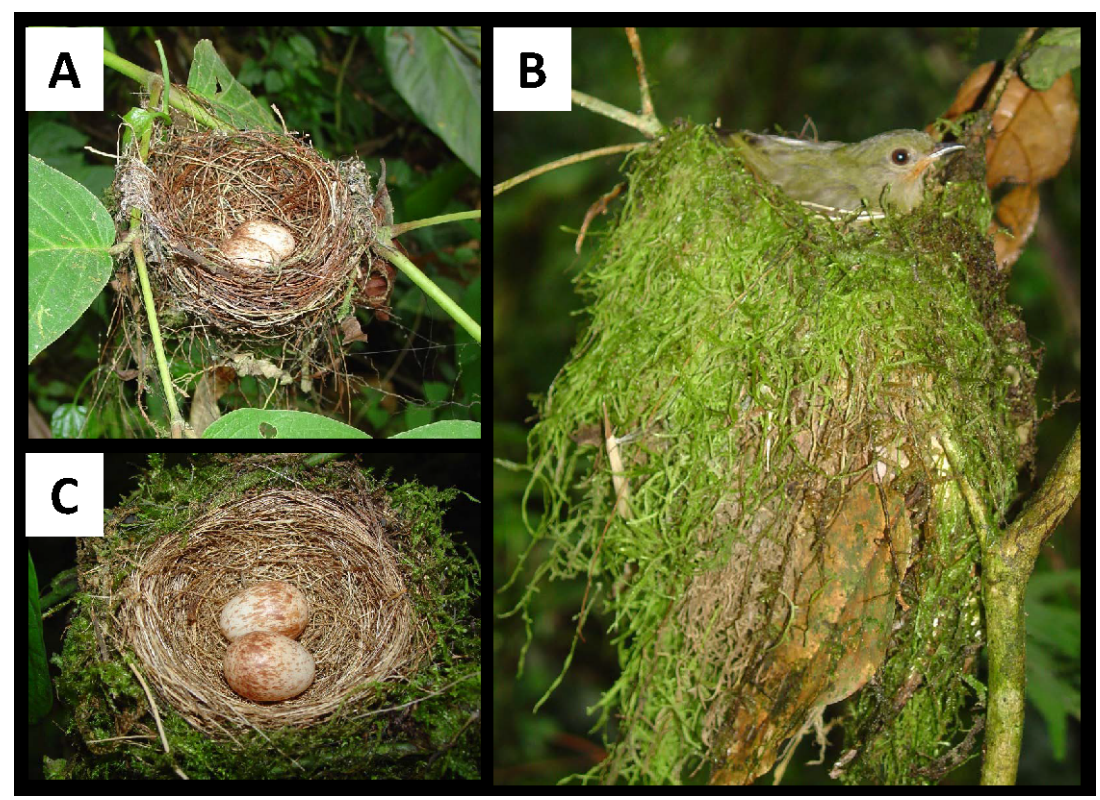

Figure 12: Nesting biology of birds of the Tumbesian Bioregion of Ecuador and Peru. For location details see Table 1. A) Nest and complete clutch of White-bearded Manakin Manacus manacus, 30 January 2004, Buenaventura (HFG); B) Adult female Club-winged Manakin Machaeopterus deliciosus on its nest, 6 February 2004, Buenaventura (HFG); C) Nest and complete clutch of M. deliciosus, 10 February 2004, Buenaventura (HFG). 


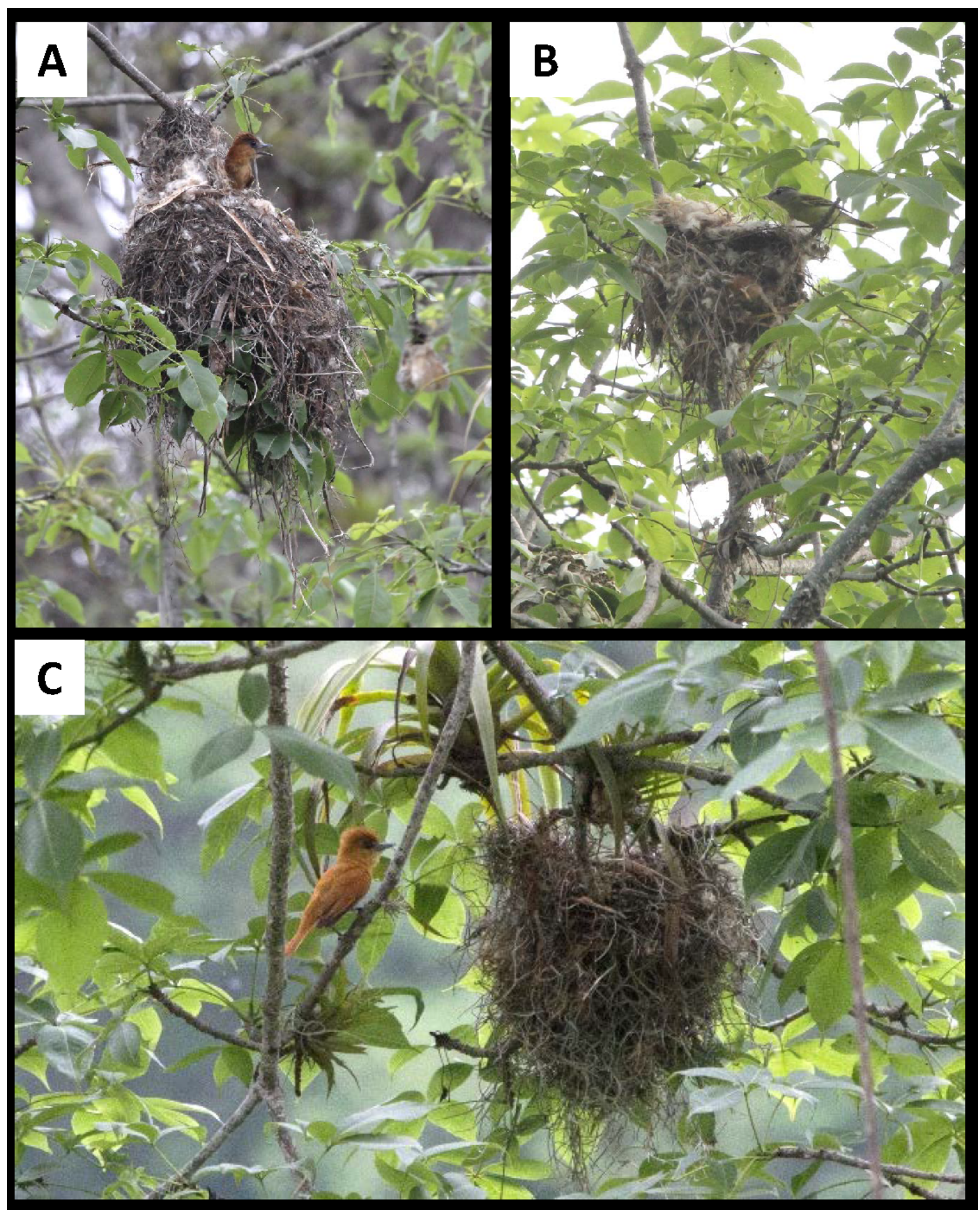

Figure 13: Nesting biology of birds of the Tumbesian Bioregion of Ecuador and Peru. For location details see Table 1. A) Adult female One-colored Becard Pachyramphus homochrous at nest, 26 February 2010, Jorupe; B) Adult female Blackand-white Becard Pachyramphus albogriseus at its nest, 7 March 2014, Jorupe; C) Adult female Slaty Becard Pachyramphus spodiurus at its nest, 25 February 2014 (HFG). 


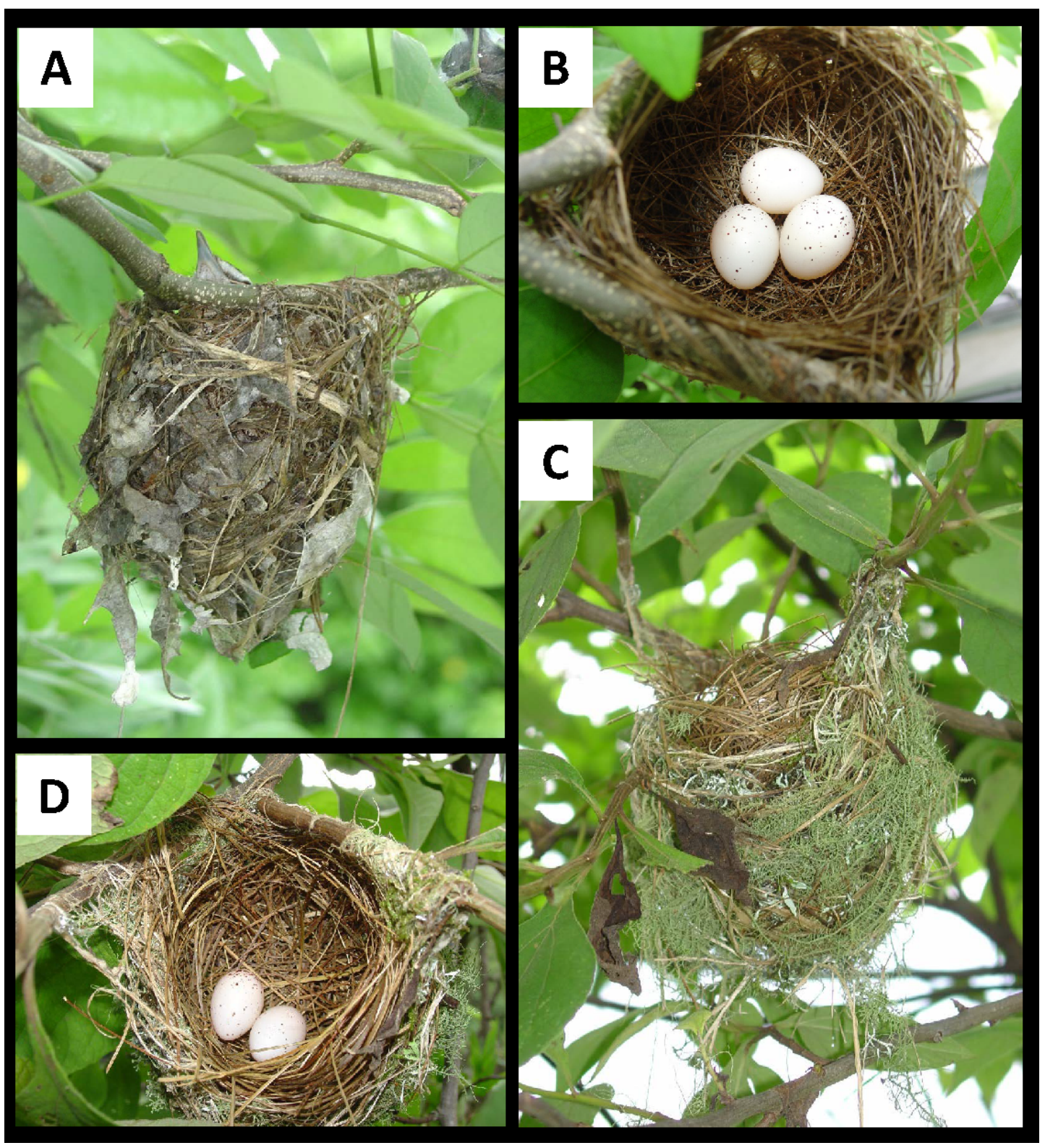

Figure 14: Nesting biology of birds of the Tumbesian Bioregion of Ecuador and Peru. For location details see Table 1. AB) Nest and complete clutch of Red-eyed Vireo Vireo olivaceus, 26 February 2006, Cerro Blanco (HFG); C-D) Nest, with two fresh eggs, of Rufous-browed Peppershrike Cyclarhis gujanensis, 15 March 2005, Yunguilla (HFG). 


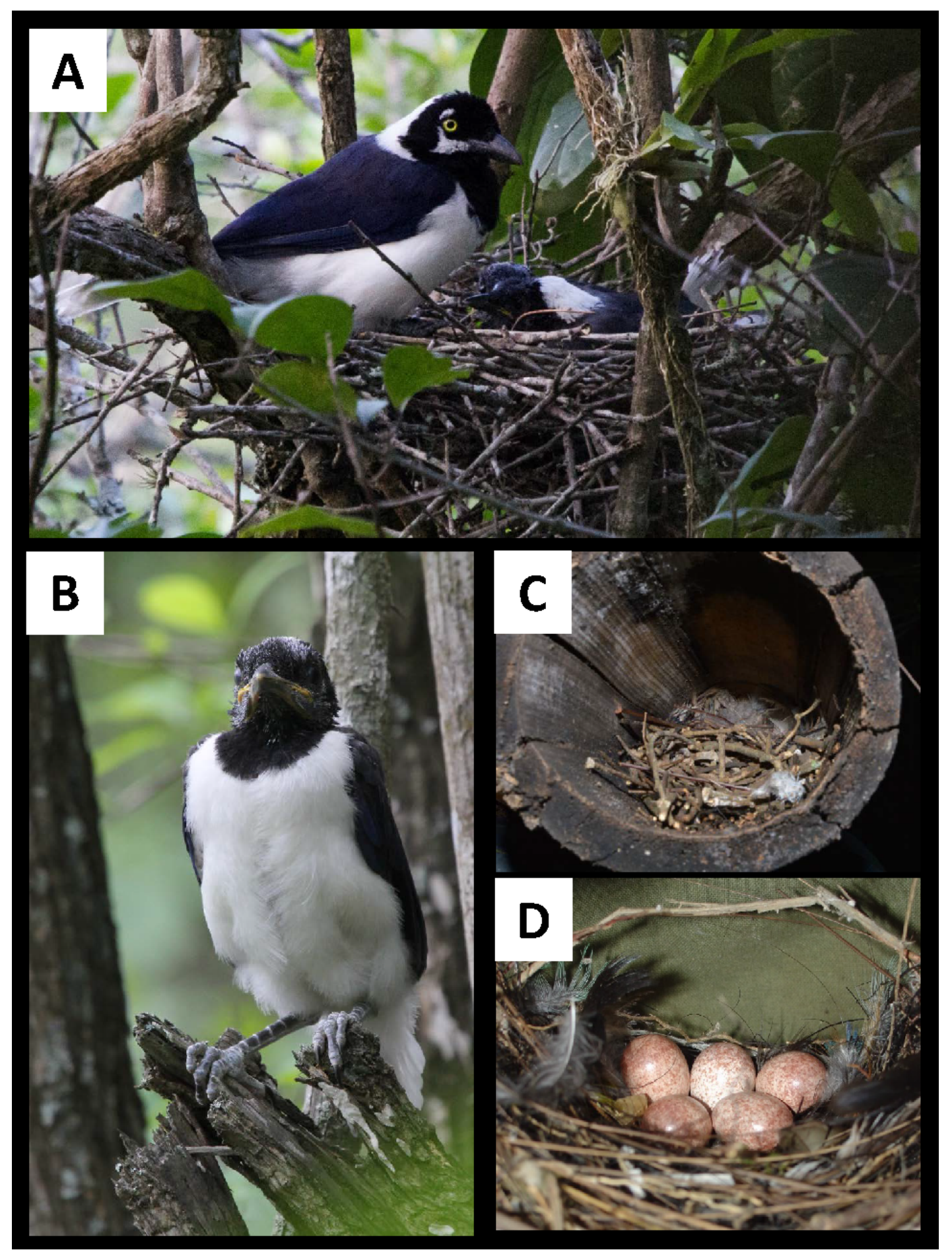

Figure 15: Nesting biology of birds of the Tumbesian Bioregion of Ecuador and Peru. For location details see Table 1. A) Adult White-tailed Jay Cyanocorax mystacalis attending older nestlings, 7 March 2014, Jorupe (HFG); B) Fledgling C. mystacalis, 7 March 2014, Jorupe (HFG); C) Nest of House Wren Troglodytes aedon, 28 March 2014, Jorupe (LASM); D) Nest and complete clutch of T. aedon, 11 February 2004, Buenaventura (HFG). 


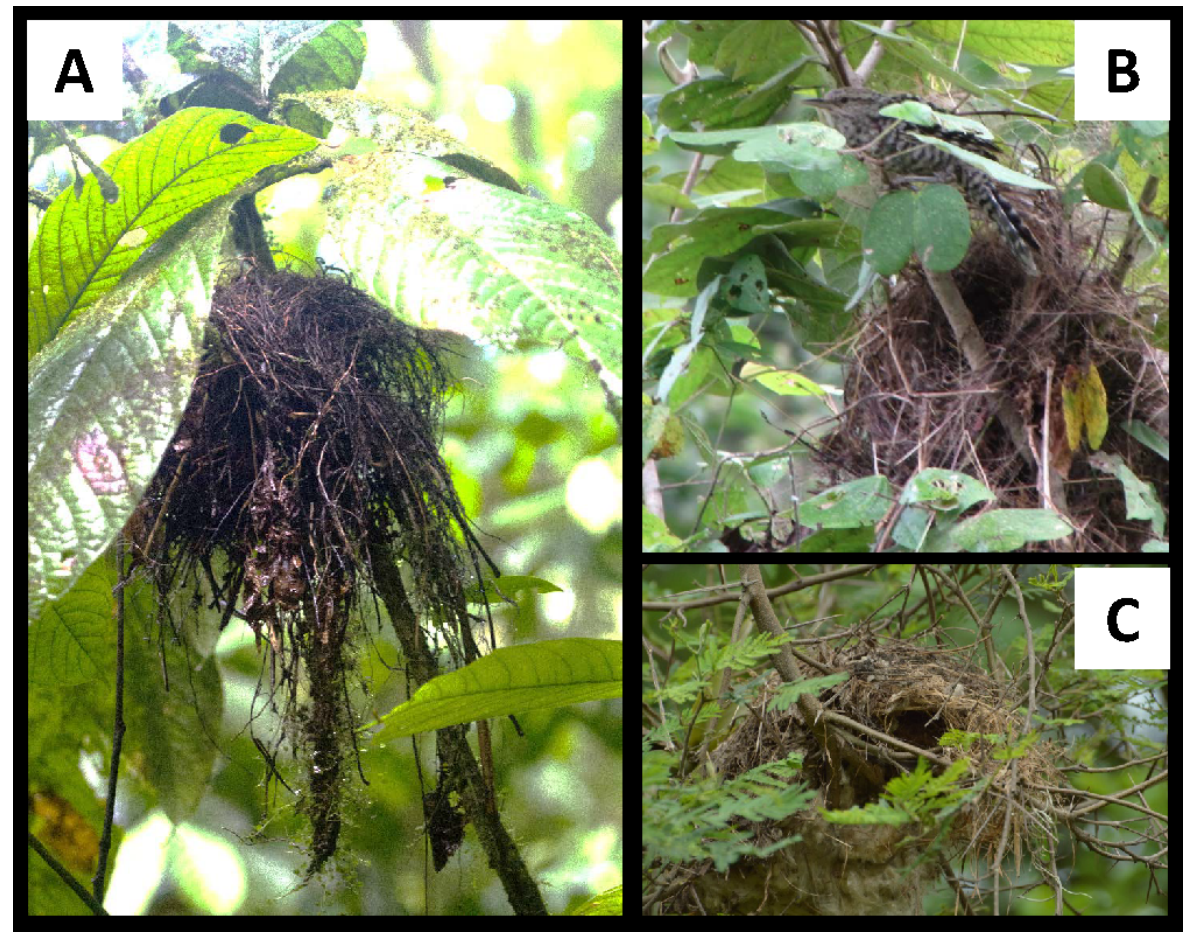

Figure 16: Nesting biology of birds of the Tumbesian Bioregion of Ecuador and Peru. For location details see Table 1. A) Nest of Bay Wren Cantorchilus nigricapillus, 24 February 2004, Buenaventura (HFG); B) Adult Fasciated Wren Campylorhynchus fasciatus outside its nest, 10 June 2009, Chignia Alta (FAP); C) Nest of Campylorhynchus fasciatus, 27 March 2014, Jorupe (LASM).

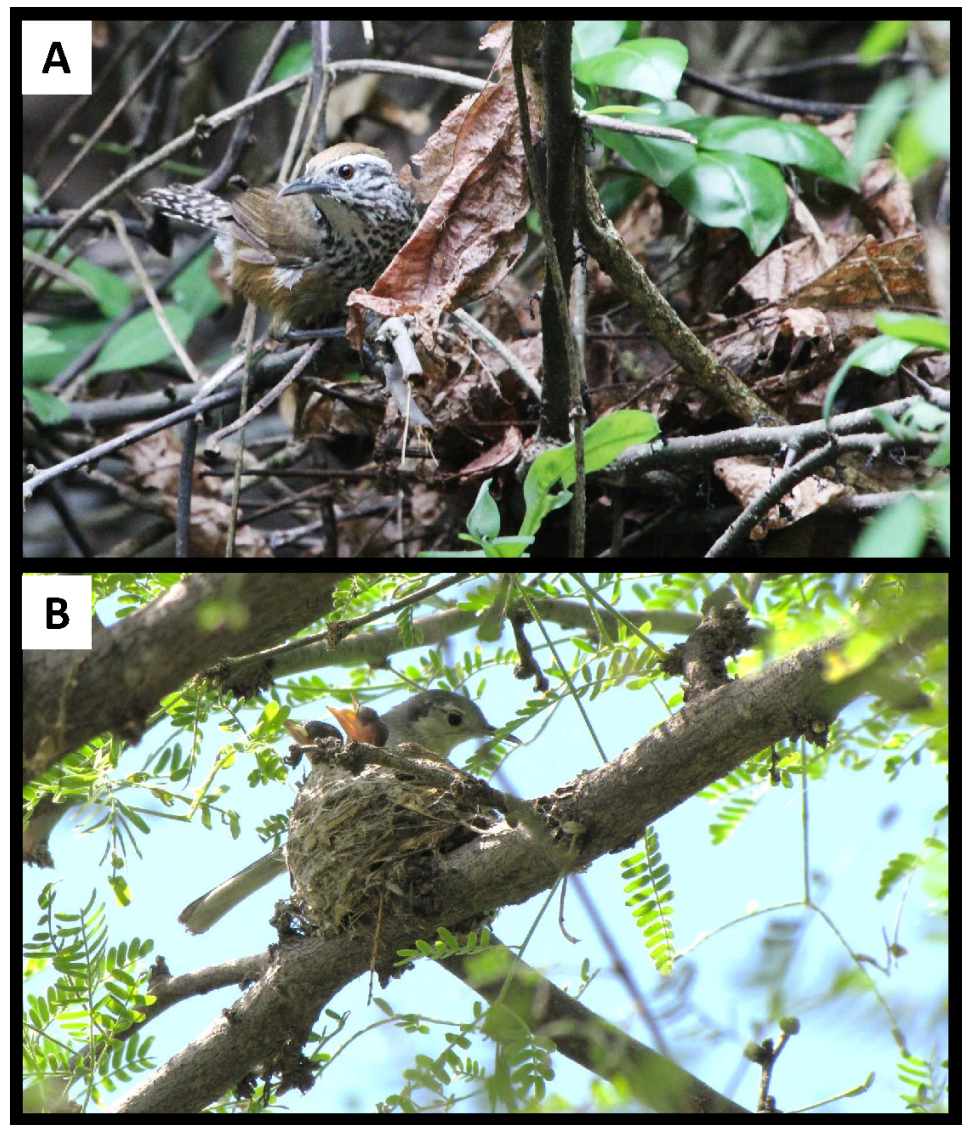

Figure 17: Nesting biology of birds of the Tumbesian Bioregion of Ecuador and Peru. For location details see Table 1. A) Adult Speckle-breasted Wren Pheugopedius sclateri just beginning nest construction, 2 March 2014, Jorupe (HFG); B) Tropical Gnatcatcher Polioptila plumbea attending nest with young nestlings, 25 March 2009, Abra de Huacrupe (FAP). 

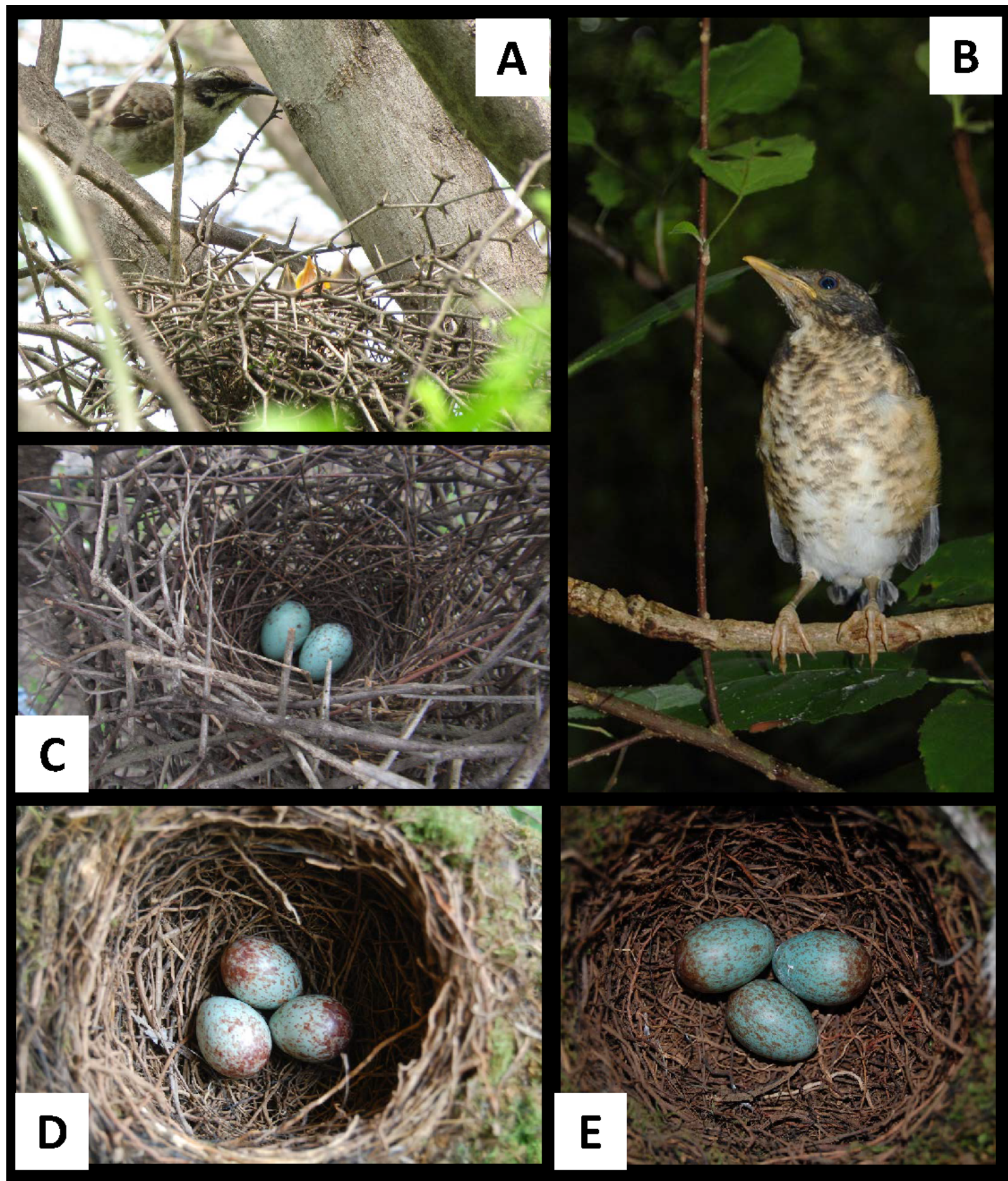

Figure 18: Nesting biology of birds of the Tumbesian Bioregion of Ecuador and Peru. For location details see Table 1. A) Adult Long-tailed Mockingbird Mimus longicaudatus feeding nestlings, 25 March 2009, Abra de Huacrupe (FAP); B) Recently fledged young of Plumbeous-backed Thrush Turdus reevei, 21 February 2010, Jorupe (HFG); C) Nest and complete clutch of $M$. longicaudatus, 7 March 2014, Macará-Loja road (HFG); D) Complete clutch of T. reevei, 11 February 2010, Jorupe (HFG); E) Complete clutch of Ecuadorian Thrush Turdus maculirostris, 11 February 2010, Jorupe (HFG). 


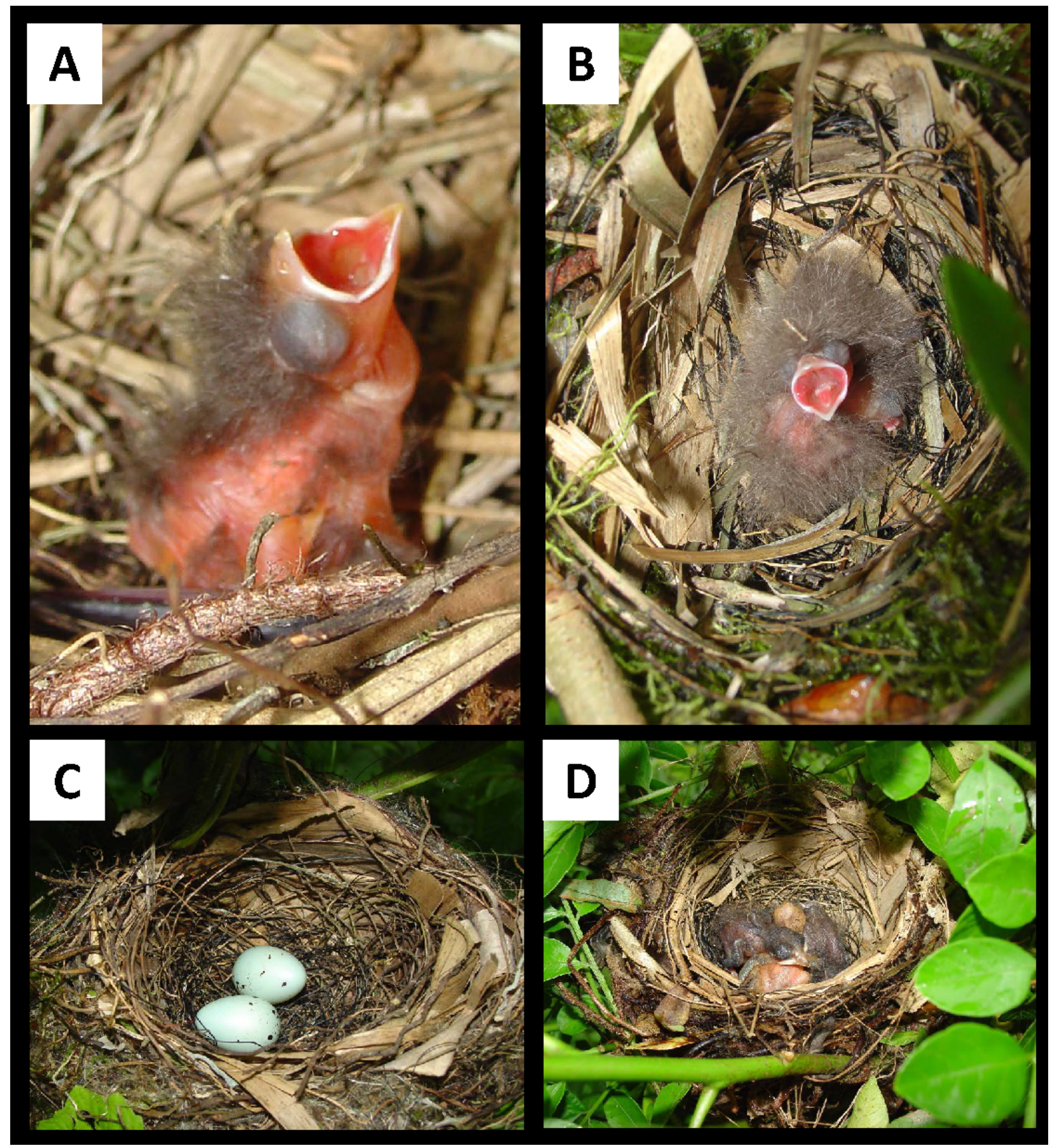

Figure 19: Nesting biology of birds of the Tumbesian Bioregion of Ecuador and Peru. For location details see Table 1. A) Newly hatched young of Palm Tanager Thraupis palmarum, 11 February 2004, Buenaventura (HFG); B) Nest and two newly-hatched young of Blue-gray Tanager Thraupis episcopus, 7 February 2004, Buenaventura (HFG); C) Nest and complete clutch of Flame-rumped Tanager Ramphocelus flammigerus, 15 February 2004, Buenaventura (HFG); D) Nest of $R$. flammigerus containing two young tanager nestlings and one of Shiny Cowbird Molothrus bonariensis, 15 February 2004, Buenaventura (HFG). 

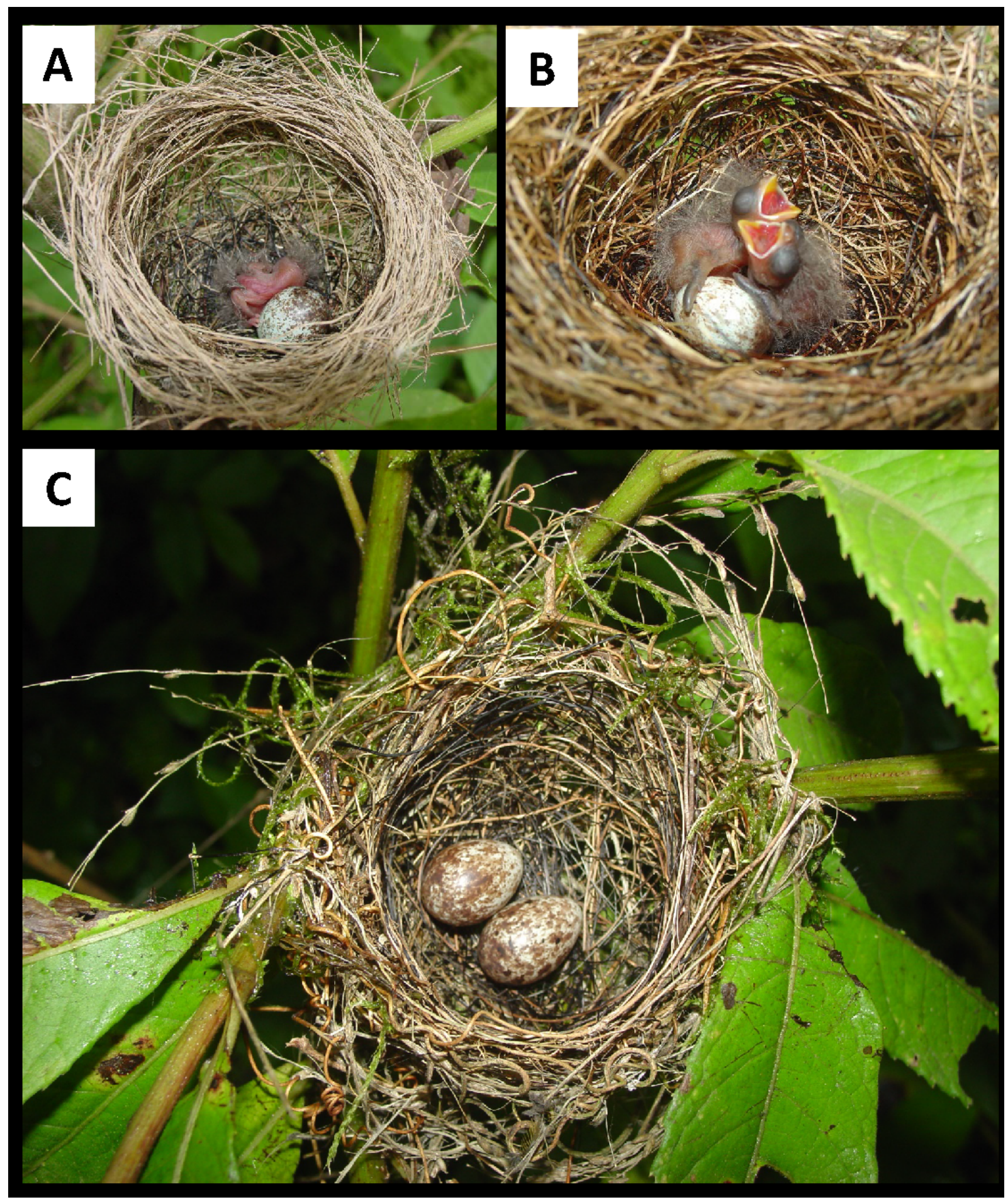

Figure 20: Nesting biology of birds of the Tumbesian Bioregion of Ecuador and Peru. For location details see Table 1. A) Newly hatched nestling and unhatched egg of Yellow-bellied Seedeater Sporophila nigricollis, 23 March 2004, Buenaventura (HFG); B) Newly hatched nestlings and unhatched egg of Thick-billed Seed-Finch Sporophila funerea, 3 February 2004, Buenaventura (HFG); C) Nest and complete clutch of Variable Seedeater Sporophila corvina, 11 February 2004, Buenaventura (HFG). 


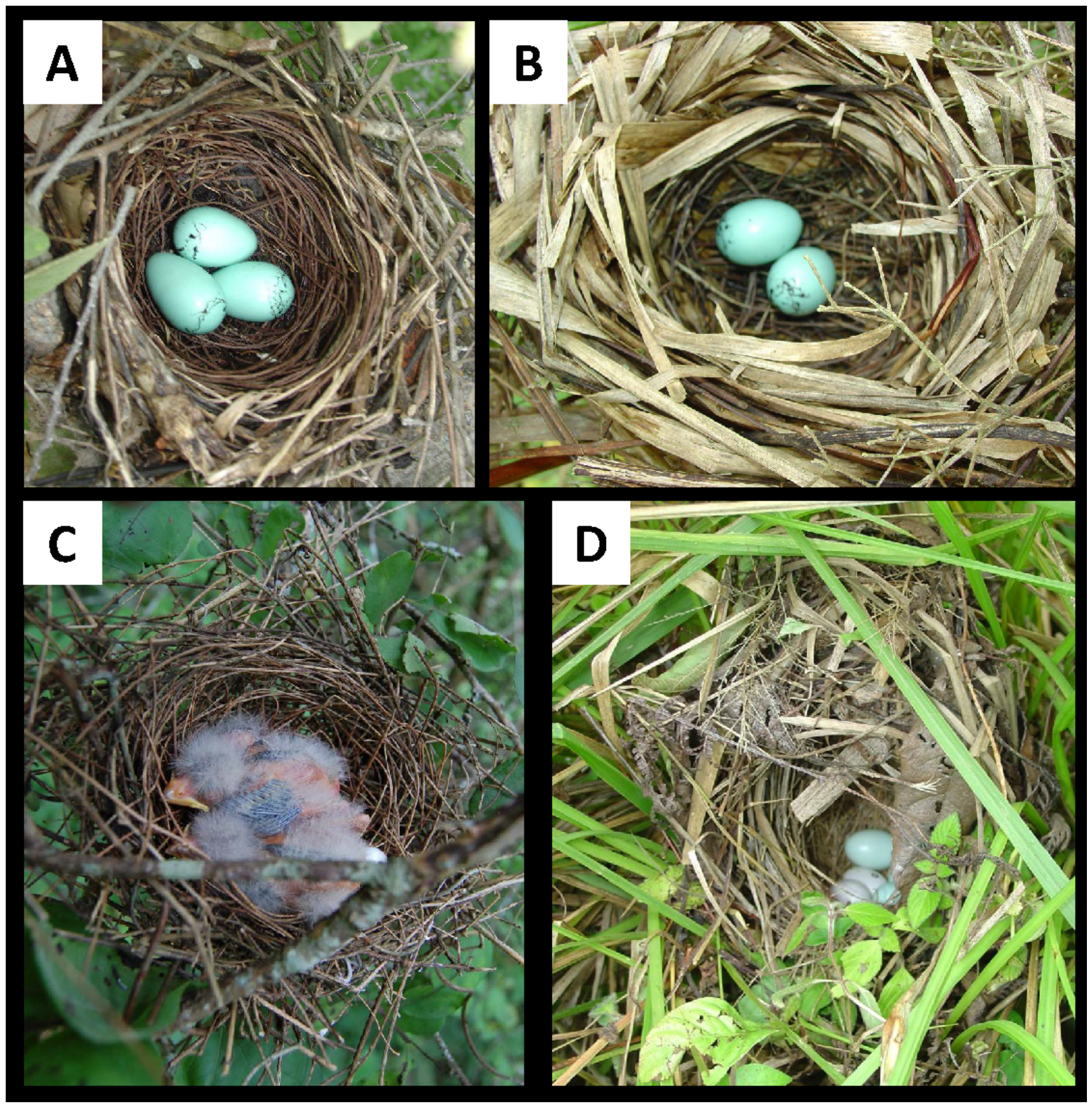

Figure 21: Nesting biology of birds of the Tumbesian Bioregion of Ecuador and Peru. For location details see Table 1. A) Nest and complete clutch of Streaked Saltator Saltator striatipectus, 25 February 2006, Cerro Blanco (HFG); B) Nest and complete clutch of Buff-throated Saltator Saltator maximus, 7 February 2004, Buenaventura (HFG); C) Nest with two young nestlings of Golden Grosbeak Pheucticus chrysogaster, 18 February 2010, Jorupe (HFG); D) Nest of Black-striped Sparrow Arremonops conirostris containing four sparrow eggs and two eggs of Shiny Cowbird Molothrus bonariensis, 11 February 2004, Buenaventura (HFG). 


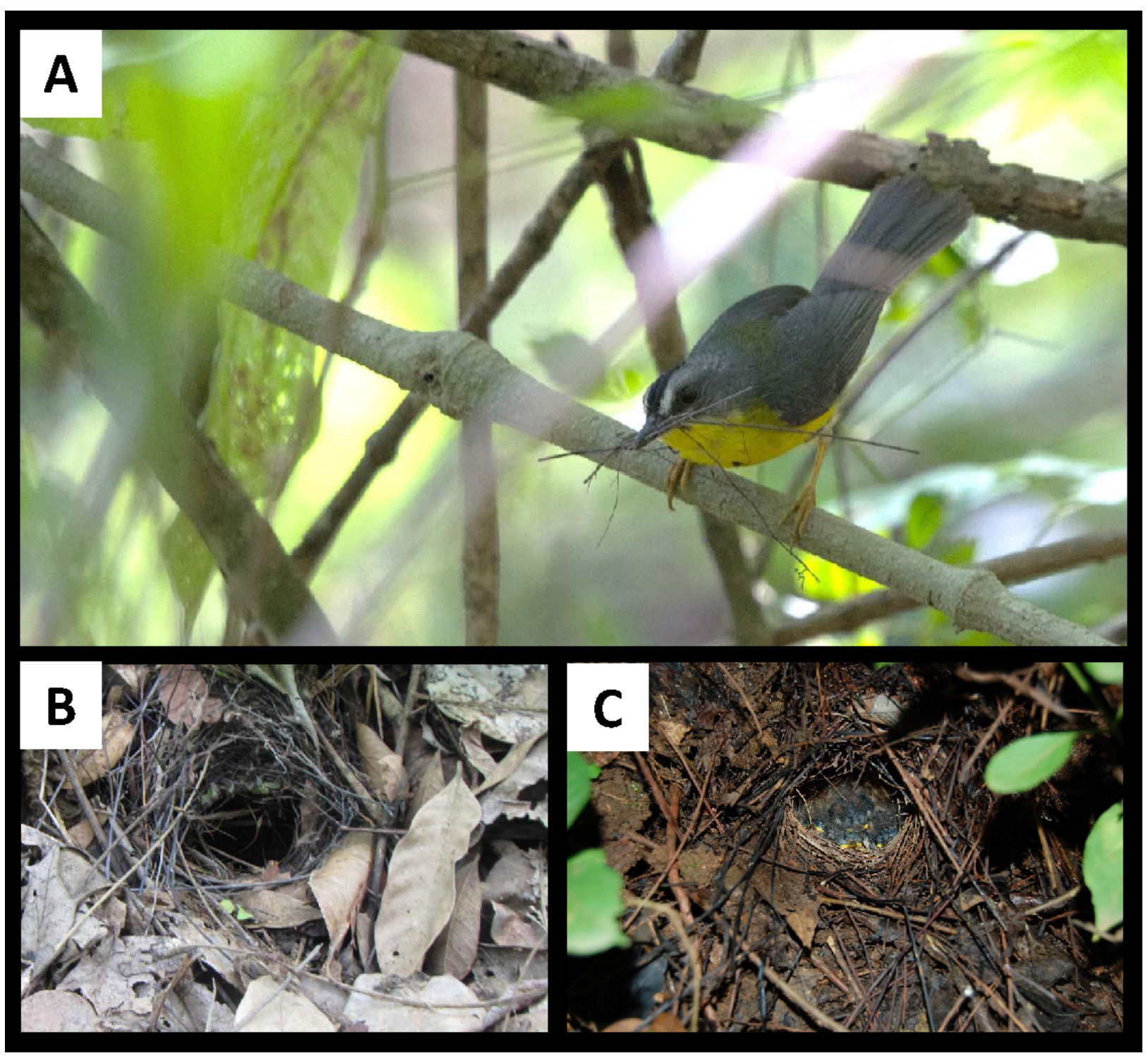

Figure 22: Nesting biology of birds of the Tumbesian Bioregion of Ecuador and Peru. For location details see Table 1. AB) Adult Gray-and-gold Warbler Myiothlypis fraseri carrying nesting material to nearly completed nest, 6 March 2014, Jorupe (HFG); Nest of $M$. fraseri with four mid-aged nestlings, 14 February 2010, Jorupe (HFG). 


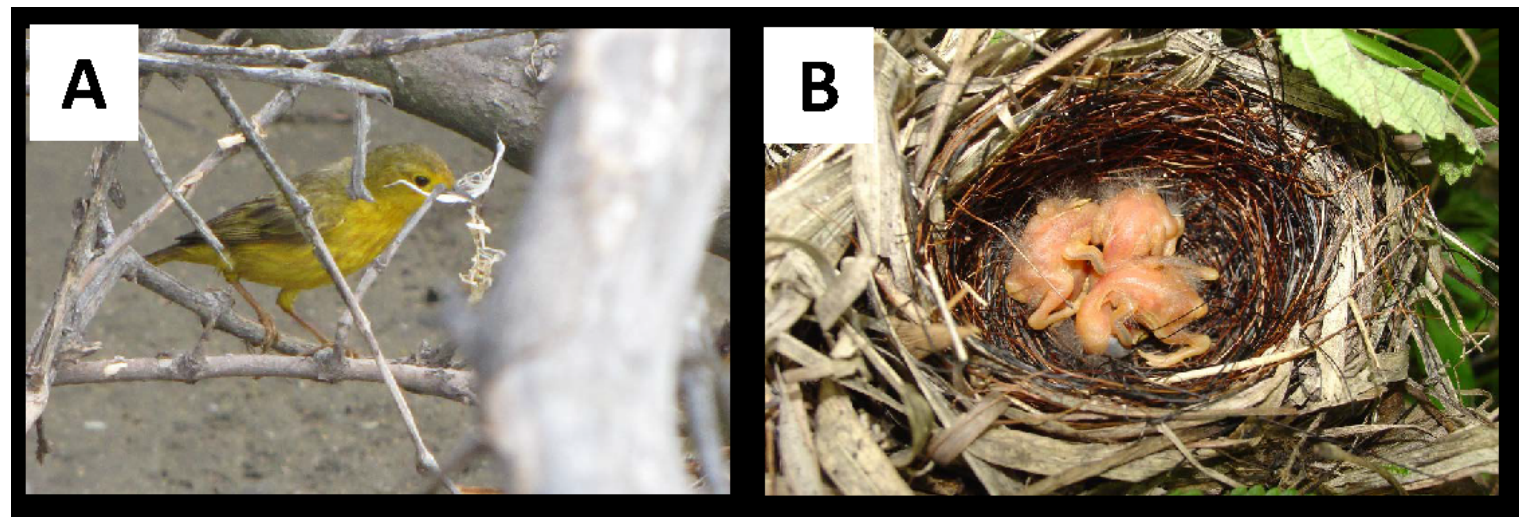

Figure 23: Nesting biology of birds of the Tumbesian Bioregion of Ecuador and Peru. For location details see Table 1. A) Adult Yellow Warbler Setophaga petechia carrying nesting material, 29 February 2009, Manglares San Pedro de Vice (FAP); B) Nest with three newly-hatched nestlings of Masked Yellowthroat Geothlypis aequinoctialis, 18 March 2005, Yunguilla (HFG).

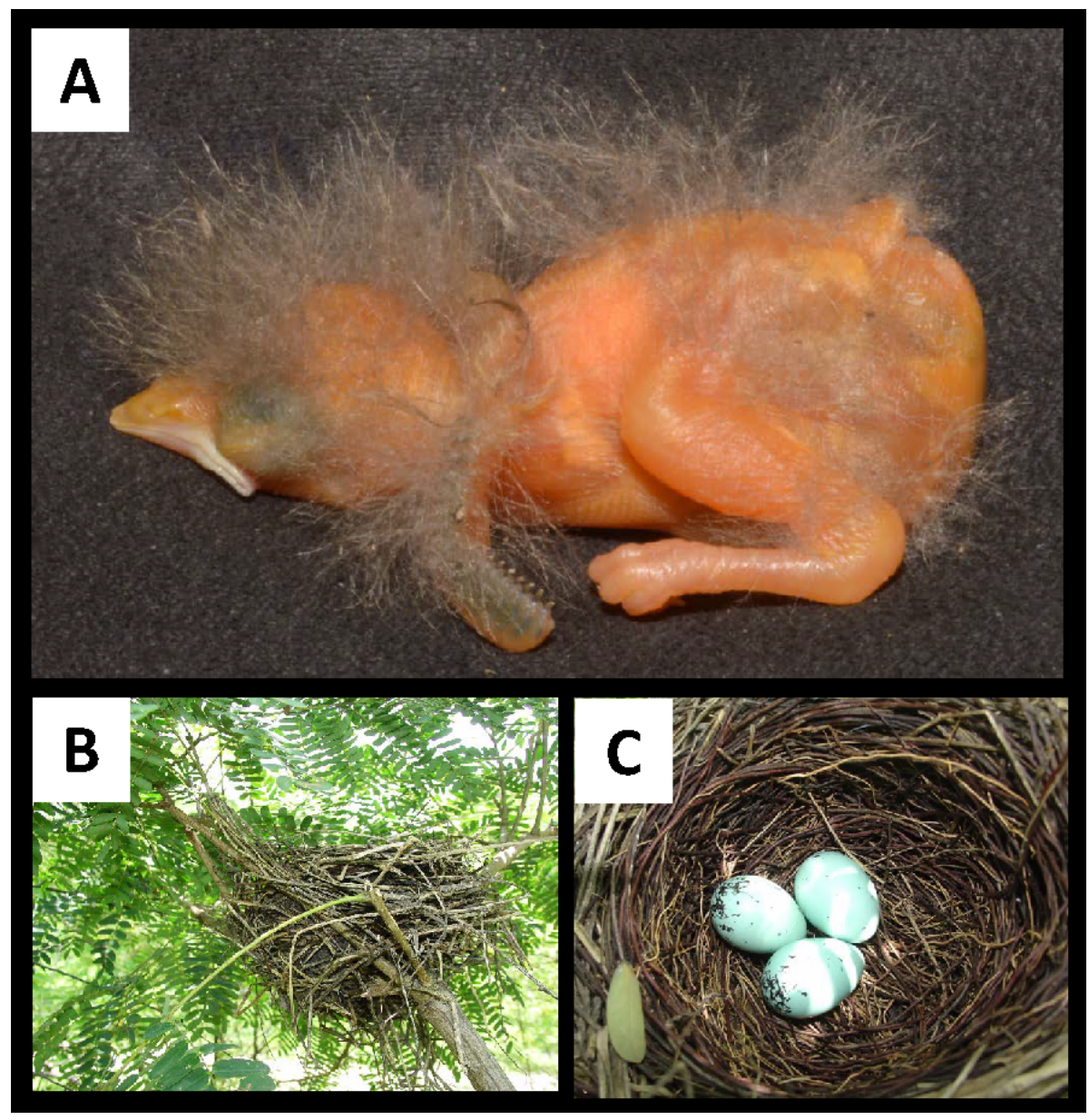

Figure 24: Nesting biology of birds of the Tumbesian Bioregion of Ecuador and Peru. For location details see Table 1. A) Recently-hatched nestling of Yellow-tailed Oriole Icterus mesomelas, 5 April 2014, Jorupe (LASM); B-C) Nest and completed clutch of Scrub Blackbird Dives warczewiczi, 28 February 2006, Jorupe (HFG).

Table 2: Summary of breeding observations for 197 species of birds in the Tumbesian region of southwest Ecuador and northwest Peru. See Table 1 for a list of locality abbreviations. In addition, we use the following abbreviations for reproductive activity: (B) building; (L) laying, clutch still being completed; (I) incubating; (N) nestlings; (F) fledglings; (J) juvenile; (AN) active nest at unknown stage; (CF) adult carrying food, but unknown if intended delivery was for a mate, nestlings, or fledglings; (CM) carrying nesting material but nest unseen. 


\begin{tabular}{lllll}
\hline English name & Date & $\begin{array}{l}\text { Breed. } \\
\text { activ. }\end{array}$ & Locality & Observations \\
Scientific name & & &
\end{tabular}

\begin{tabular}{|c|c|c|c|c|}
\hline Pale-browed & 19 Apr 2006 & $\mathbf{J}$ & EC3 & immature individual with pink legs. \\
\hline $\begin{array}{l}\text { Tinamou } \\
\text { Crypturellus }\end{array}$ & 18 Jun 2008 & $\mathrm{~J}$ & TTU6 & \\
\hline \multirow[t]{4}{*}{ transfasciatus } & 25 Mar 2014 & $\mathrm{I}$ & EC3 & $\begin{array}{l}4 \text { eggs }(47 \times 38 \mathrm{~mm}, 31.8 \mathrm{~g} ; 46 \times 36 \mathrm{~mm}, 29.8 \\
\text { g; } 45 \times 36 \mathrm{~mm}, 25.7 \mathrm{~g} ; 46 \times 35 \mathrm{~mm}, 28.2 \mathrm{~g}) \\
\text { (Fig. 1a). }\end{array}$ \\
\hline & 15 Apr 2009 & $\mathrm{~F}$ & TZA1 & \\
\hline & 11 Feb 2010 & I & EC3 & $\begin{array}{l}5 \text { eggs, last one laid } 15 \mathrm{Feb}(45.8 \times 37.4 \mathrm{~mm} \text {, } \\
25.23 \mathrm{~g} ; 45.4 \times 38.0 \mathrm{~mm}, 36.49 \mathrm{~g} ; 43.2 \times 37.1 \\
\mathrm{~mm}, 32.65 \mathrm{~g} ; 44.5 \times 37.7 \mathrm{~mm}, 34.16 \mathrm{~g} ; 44.2 \times \\
36.9 \mathrm{~mm}, 33.15 \mathrm{~g})(\text { Fig. } 1 \mathrm{~b})\end{array}$ \\
\hline & 5 Jul 2010 & $\mathrm{~J}$ & TTU4 & \\
\hline $\begin{array}{l}\text { Fulvous-bellied } \\
\text { Whistling-Duck } \\
\text { Dendrocygna } \\
\text { bicolor }\end{array}$ & 6 Apr 2011 & $\mathrm{~F}$ & EC18 & 2 adults followed by 4 young ducklings. \\
\hline \multirow[t]{2}{*}{$\begin{array}{l}\text { Black-bellied } \\
\text { Whistling-Duck } D \text {. } \\
\text { autumnalis }\end{array}$} & 16 Apr 2011 & $\mathrm{~F}$ & EC26 & $\begin{array}{l}8 \text { young, recently hatched, following adult, } \\
\text { brood was attacked by an adult, biting they } \\
\text { young. }\end{array}$ \\
\hline & 16 Apr 2011 & $\mathrm{~F}$ & EC26 & $\begin{array}{l}7 \text { young about half adult sized, following } \\
\text { adult. }\end{array}$ \\
\hline $\begin{array}{l}\text { White-cheeked } \\
\text { Pintail Anas } \\
\text { bahamensis }\end{array}$ & 5 Mar 2016 & $\mathrm{~F}$ & $\mathrm{LCH} 2$ & $\begin{array}{l}\text { many adults (c. } 40) \text {, at least } 30 \text { older young on } \\
\text { a small pond. }\end{array}$ \\
\hline $\begin{array}{l}\text { Chilean Flamingo } \\
\text { Phoenicopterus } \\
\text { chilensis }\end{array}$ & 27 Jan 2016 & $\mathrm{~J}$ & PPI01 & 6 immature birds. \\
\hline Least Grebe & 24 Feb 2006 & $\mathrm{~F}$ & $\mathrm{EC} 1$ & 4 fledglings following adults. \\
\hline \multirow[t]{9}{*}{ dominicus } & $\begin{array}{l}22 \text { May } \\
2012\end{array}$ & $\mathrm{~J}$ & LLA8 & at least 10 juveniles on a pond. \\
\hline & 16 Apr 2011 & I & EC18 & 3 eggs. \\
\hline & 16 Apr 2011 & I & EC18 & 3 eggs. \\
\hline & 16 Apr 2011 & $\mathrm{~N}$ & EC18 & $\begin{array}{l}\text { adult with recently hatched chick capable of } \\
\text { swimming. }\end{array}$ \\
\hline & 16 Apr 2011 & $\mathrm{~N}$ & EC18 & 3 chicks, just hatched. \\
\hline & 16 Apr 2011 & $\mathrm{~N}$ & EC18 & 3 chicks in nest, maybe one day old. \\
\hline & 16 Apr 2011 & $\mathrm{~F}$ & EC18 & adult with two young, estimated 1 week old. \\
\hline & 16 Apr 2011 & $\mathrm{~F}$ & EC18 & adult with 2 young about half of adult size. \\
\hline & 16 Apr 2011 & $\mathrm{~F}$ & EC18 & 2 chicks, near adult size, following adult. \\
\hline $\begin{array}{l}\text { Pied-billed Grebe } \\
\text { Podilymbus }\end{array}$ & 16 Apr 2011 & $\mathrm{AN}$ & EC18 & $\begin{array}{l}\text { adult sitting on floating nest, second adult } \\
\text { nearby. }\end{array}$ \\
\hline \multirow[t]{3}{*}{ podiceps } & 16 Apr 2011 & $\mathrm{~F}$ & EC18 & two young following adults. \\
\hline & 16 Apr 2011 & $\mathrm{~F}$ & EC18 & adult followed by 2 chicks. \\
\hline & 24 Mar 2015 & $\mathrm{~F}$ & EC18 & $\begin{array}{l}\text { adult with } 2 \text { tiny, spotted young perched on its } \\
\text { back. }\end{array}$ \\
\hline White-tipped Dove & 25 Feb 2006 & $\mathrm{~N}$ & $\mathrm{EC} 1$ & 2 eggs, one just hatched and other hatching. \\
\hline \multirow[t]{6}{*}{ Leptotila verreauxi } & 8 Jun 2009 & $\mathrm{~L}$ & PHU2 & both eggs just starting development. \\
\hline & 8 Jun 2009 & Copul. & PHU2 & \\
\hline & 12 Feb 2010 & I & EC3 & $\begin{array}{l}2 \text { buffy-white eggs } 30.53 \times 21.83 \mathrm{~mm}, 7.43 \mathrm{~g} \\
\text { and } 28.04 \times 21.18 \mathrm{~mm}, 6.57 \mathrm{~g} \text {, hatched } 21 \mathrm{Feb} \\
\text { fledged } 7 \text { Mar. }\end{array}$ \\
\hline & 19 Feb 2010 & I & EC3 & $\begin{array}{l}2 \text { buffy-white eggs } 29.38 \times 22.72 \mathrm{~mm}, 7.63 \mathrm{~g} \\
\text { and } 28.98 \times 23.13 \mathrm{~mm}, 7.95 \mathrm{~g} .\end{array}$ \\
\hline & 27 Feb 2010 & $\mathrm{I}$ & PAY2 & $1.6 \mathrm{~m}$ up in Prosopis pallida tree. \\
\hline & 17 Jan 2011 & $\mathrm{I}$ & $\mathrm{EC} 1$ & $2 \mathrm{~m}$ up, 2 eggs. \\
\hline
\end{tabular}




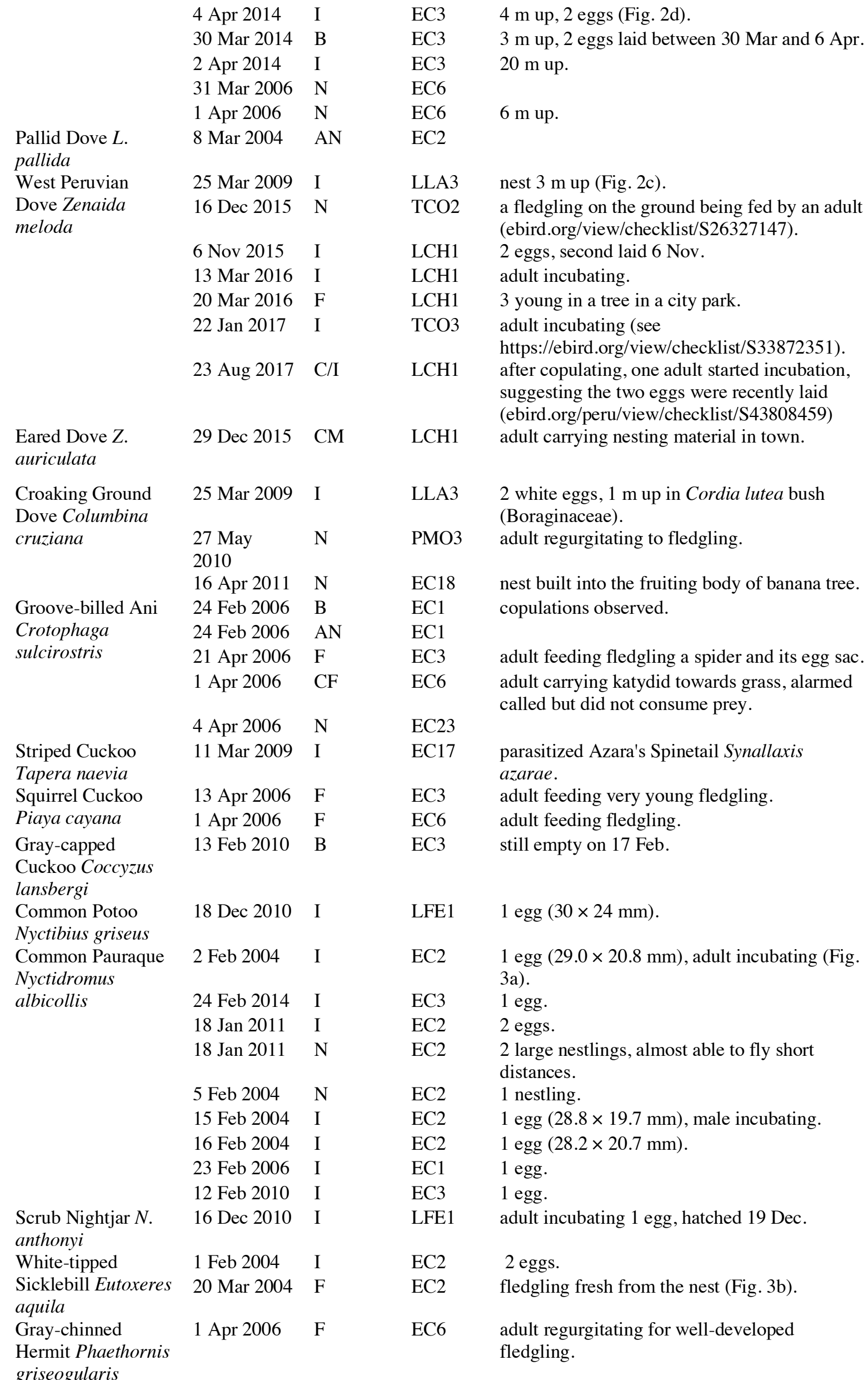




\begin{tabular}{|c|c|c|c|c|}
\hline $\begin{array}{l}\text { Rufous-tailed } \\
\text { Hummingbird } \\
\text { Amazilia tzacatl }\end{array}$ & 21 Mar 2004 & AN & $\mathrm{EC} 2$ & $\begin{array}{l}3 \mathrm{~m} \text { up, saddled over leaf petiole of unknown } \\
\text { plant, well attached to stem and petiole with } \\
\text { spider webs. } \\
\text { adult carrving lichens }\end{array}$ \\
\hline $\begin{array}{l}\text { Amazilia } \\
\text { Hummingbird } A \text {. } \\
\text { amazilia }\end{array}$ & 10 Apr 2006 & B & EC3 & $\begin{array}{l}\text { adult observed removing material from an } \\
\text { abandoned Pachyramphus sp. nest. } \\
3.5 \mathrm{~m} \text { up saddled over a thin branch. }\end{array}$ \\
\hline $\begin{array}{l}\text { Purple Gallinule } \\
\text { Porphyrio } \\
\text { martinica }\end{array}$ & $\begin{array}{l}21 \text { May } \\
2012 \\
16 \text { Apr } 2011 \\
16 \text { Apr } 2011 \\
16 \text { Apr } 2011 \\
16 \text { Apr } 2011 \\
16 \text { Apr } 2011 \\
16 \text { Apr } 2011\end{array}$ & $\begin{array}{l}\text { F } \\
\text { F } \\
\text { F } \\
\text { F } \\
\text { F } \\
\text { F }\end{array}$ & $\begin{array}{l}\text { EC18 } \\
\text { EC18 } \\
\text { EC18 } \\
\text { EC18 } \\
\text { EC18 } \\
\text { EC18 }\end{array}$ & $\begin{array}{l}2 \text { downy black chicks with an adult, walking } \\
\text { on floating vegetation in a pond. } \\
2 \text { young with adult. } \\
1 \text { young with adult. } \\
2 \text { downy, black young with adult. } \\
2 \text { downy, black young with adult. } \\
\text { adult with two young, about half adult size. } \\
\text { adult with single, young juvenile. }\end{array}$ \\
\hline $\begin{array}{l}\text { White-throated } \\
\text { Crake Laterallus } \\
\text { albigularis }\end{array}$ & $\begin{array}{l}6 \text { Apr } 2011 \\
6 \text { Apr } 2011\end{array}$ & $\begin{array}{l}\mathrm{B} \\
\mathrm{N}\end{array}$ & $\begin{array}{l}\text { EC18 } \\
\text { EC18 }\end{array}$ & $\begin{array}{l}\text { see previous record. } \\
\text { at least } 10 \text { adults followed by young juveniles, } \\
\text { many more followed by older young. }\end{array}$ \\
\hline $\begin{array}{l}\text { Rufous-necked } \\
\text { Wood-Rail } \\
\text { Aramides axillaris }\end{array}$ & $\begin{array}{l}9 \text { Apr } 2006 \\
21 \text { Apr } 2006\end{array}$ & $\begin{array}{l}\mathrm{J} \\
\mathrm{J}\end{array}$ & $\begin{array}{l}\mathrm{EC} 3 \\
\mathrm{EC} 3\end{array}$ & $\begin{array}{l}\text { adult foraging with at least one juvenile. } \\
\text { flushed juvenile up into low branch, adult } \\
\text { scolding nearby. }\end{array}$ \\
\hline & 12 Feb 2010 & I & EC3 & $\begin{array}{l}\text { second egg laid } 12 \text { Feb, final (6th) egg laid } 17 \\
\text { Feb (Fig. 2a), first hatch on } 10 \text { Mar, last on } 11 \\
\text { or } 12 \text { Mar. }\end{array}$ \\
\hline & 18 Feb 2010 & I & EC3 & $\begin{array}{l}5.2 \mathrm{~m} \text { up in tangle of branches, } 6 \text { eggs, eggs } \\
\text { hatch } 20-21 \mathrm{Feb} \text { (Fig. 2b). }\end{array}$ \\
\hline & 29 Feb 2010 & B & EC3 & $\begin{array}{l}\text { found with } 2 \text { eggs, 6th (final) egg laid } 6 \text { Mar, } \\
2.5 \mathrm{~m} \text { up. }\end{array}$ \\
\hline $\begin{array}{l}\text { Common Gallinule } \\
\text { Gallinula galeata }\end{array}$ & 16 Apr 2011 & $\mathrm{~F}$ & EC18 & $\begin{array}{l}2 \text { adults bringing dead, brown grass or sedge } \\
\text { leaves to a recently started nest, } 15 \mathrm{~cm} \text { above } \\
\text { wet ground, one adult followed by small chick } \\
\text { with blackish down, at one point this chick } \\
\text { climbed into new, on } 16 \text { Apr } 2011 \text { nest } \\
\text { underwater and empty. }\end{array}$ \\
\hline Wilson's Plover & 6 Aug 2010 & $\mathrm{~F}$ & PSE1 & \\
\hline $\begin{array}{l}\text { Charadrius } \\
\text { wilsonia }\end{array}$ & 21 Jan 2017 & $\mathrm{~F}$ & TZA2 & $\begin{array}{l}\text { adult incubating a single egg. We found a } \\
\text { second egg, a few m away, possibly moved by } \\
\text { rain water during the previous night. We } \\
\text { placed the egg with that being incubated, and } \\
\text { the adult immediately covered them both (see } \\
\text { https://ebird.org/view/checklist/S33871390). } \\
\text { adult with two older young. }\end{array}$ \\
\hline $\begin{array}{l}\text { Oystercatcher } \\
\text { Haematopus } \\
\text { palliatus }\end{array}$ & 18 Jan 2018 & $\mathrm{~F}$ & PTA2 & $\begin{array}{l}2 \text { different pairs, attending } 1 \text { and } 2 \text { fledglings } \\
\text { each (ebird.org/view/checklist/S42044614). }\end{array}$ \\
\hline $\begin{array}{l}\text { Black-necked Stilt } \\
\text { Himantopus } \\
\text { mexicanus }\end{array}$ & $24 \operatorname{Mar} 2015$ & $\mathrm{AN}$ & EC18 & $\begin{array}{l}\text { nest composed of rotting vegetation, only a } \\
\text { few } \mathrm{cm} \text { above water. }\end{array}$ \\
\hline Peruvian Thick- & $23 \operatorname{Jan} 2011$ & I & LFE1 & 2 eggs, hatched ca. 2 weeks later. \\
\hline $\begin{array}{l}\text { knee Burhinus } \\
\text { superciliaris }\end{array}$ & $18 \operatorname{Mar} 2012$ & I & LFE1 & 2 eggs. \\
\hline Wattled Jacana & 16 Apr 2011 & $\mathrm{~N}$ & EC18 & 2 young nestlings. \\
\hline Jacana jacana & $\begin{array}{l}16 \text { Apr } 2011 \\
16 \text { Apr } 2011 \\
16 \text { Apr } 2011 \\
16 \text { Apr } 2011\end{array}$ & $\begin{array}{l}\mathrm{N} \\
\mathrm{N} \\
\mathrm{N} \\
\mathrm{M}\end{array}$ & $\begin{array}{l}\text { EC18 } \\
\text { EC18 } \\
\text { EC18 } \\
\text { EC18 }\end{array}$ & $\begin{array}{l}2 \text { older nestlings. } \\
1 \text { older nestling. } \\
1 \text { young nestling. } \\
1 \text { newborn nestling. }\end{array}$ \\
\hline Gray-hooded Gull & 12 Apr 2011 & I & $\mathrm{EC} 24$ & \\
\hline $\begin{array}{l}\text { Chroicocephalus } \\
\text { cirrocephalus }\end{array}$ & 12 Apr 2011 & $\mathrm{AN}$ & $\mathrm{EC} 24$ & \\
\hline & 12 Apr 2011 & AN & $\mathrm{EC} 24$ & \\
\hline
\end{tabular}




Waved Albatross
Phoebastria
irrorata
Magnificent
Frigatebird Fregata
magnificens
Black-crowned
Night-Heron
Nycticorax

12 Apr 2011 AN

$\mathrm{EC} 24$

12 Apr 2011 AN

15 Aug 2007 N

26 Jan $2016 \quad \mathrm{~N}$

21 Jan $2017 \quad \mathrm{~N}$

29 Dec $2015 \quad \mathrm{~N}$

nycticorax

Striated Heron

Butorides striata

13 Mar $2018 \quad$ J

22 May

2012

27 Feb 2006

2 May $2017 \quad \mathrm{I} / \mathrm{N}$

Cattle Egret

Bubulcus ibis

Great Egret Ardea

11 Feb 2017 C

2 May 2017 I/N

LFE2

LFE2

Snowy Egret

Egretta thula

Little Blue Heron

E. caerulea

Andean Condor
Vultur gryphus
Swallow-tailed Kite
Elanoides forficatus
Ornate Hawk-Eagle
Spizaetus ornatus
Snail Kite
Rostrhamus
sociabilis
Bicolored Hawk
Accipiter bicolor

25 Mar $2009 \quad \mathrm{~J}$

5 Jul $2010 \quad$ J

LLA3

TTU2

6 Feb $2004 \quad$ CM $\quad$ EC2

19 May $\quad$ J $\quad$ TZA1

2009

16 Apr $2011 \quad \mathrm{~N} \quad \mathrm{EC} 18$

27 Feb 2006 CM

$\mathrm{EC} 25$

15 May $\quad F \quad$ TTU1

2009

14 Feb $2011 \quad$ F $\quad$ LFE

11 Apr $2006 \mathrm{~N} \quad \mathrm{EC} 3$

Savanna Hawk

Buteogallus

meridionalis

Great Black Hawk

B. urubitinga

\begin{tabular}{|c|c|c|}
\hline 1 Mar 2009 & AN & PSE3 \\
\hline 24 Apr 2009 & $\mathrm{~N}$ & PMO3 \\
\hline 16 Jun 2009 & $\mathbf{J}$ & PMO9 \\
\hline 4 Jul 2009 & $\mathbf{J}$ & PAY3 \\
\hline Aug 2009 & $\mathbf{J}$ & PMO3 \\
\hline Oct 2009 & $\mathbf{J}$ & PMO3 \\
\hline Sep 2009 & $\mathbf{J}$ & PMO3 \\
\hline 5 Apr 2014 & $\mathrm{CM}$ & EC2 \\
\hline 12 Nov 2015 & $\mathrm{~F}$ & $\mathrm{EC} 2$ \\
\hline
\end{tabular}

1 nestling about $2 / 3$ adult size.

nest with one mid-aged nestling (Fig. 1d). nesting colony, 30+ active nests (ebird.org/view/checklist/S34612250). many adults and at least 8 older juveniles seen, two recently dead young were found on the ground, one ca. 1 day old, one $c a$. 1 week old. several juveniles sitting along a water channel. 3 fledglings seen along the margin of a pond.

2 eggs, $1 \mathrm{~m}$ above water level in flooded agricultural field (Fig. 1c).

A nesting colony of four heron species (Ardea alba, Egretta thula, E. caerulea and Bubulcus ibis). There were multiple nests of this species with nestlings and adults incubating. copula (ebird.org/view/checklist/S34325381). A nesting colony of four heron species (Ardea alba, Egretta thula, E. caerulea and Bubulcus ibis). There were multiple nests of this species with nestlings and adults incubating.

A nesting colony of four heron species (Ardea alba, Egretta thula, E. caerulea and Bubulcus ibis). There were multiple nests of this species with nestlings and adults incubating.

A nesting colony of four heron species (Ardea alba, Egretta thula, E. caerulea and Bubulcus ibis). There were multiple nests of this species with nestlings and adults incubating.

adult carrying stick.

single young near fledging.

adult carrying long stick.

fledglings making loud begging calls.

two juveniles, recently from the nest, tame.

adults feeding single, mid-aged nestling

snakes and lizards.

copulations observed.

c. 1-week-old nestling brought to town by local resident.

young recently from the nest. young recently from the nest. young recently from the nest. adult carry nest material in talons nest $c .15 \mathrm{~m}$ up in isolated pasture tree, fledgling arrived from another tree and received one small prey from and adult, consuming it while perched in nest. 


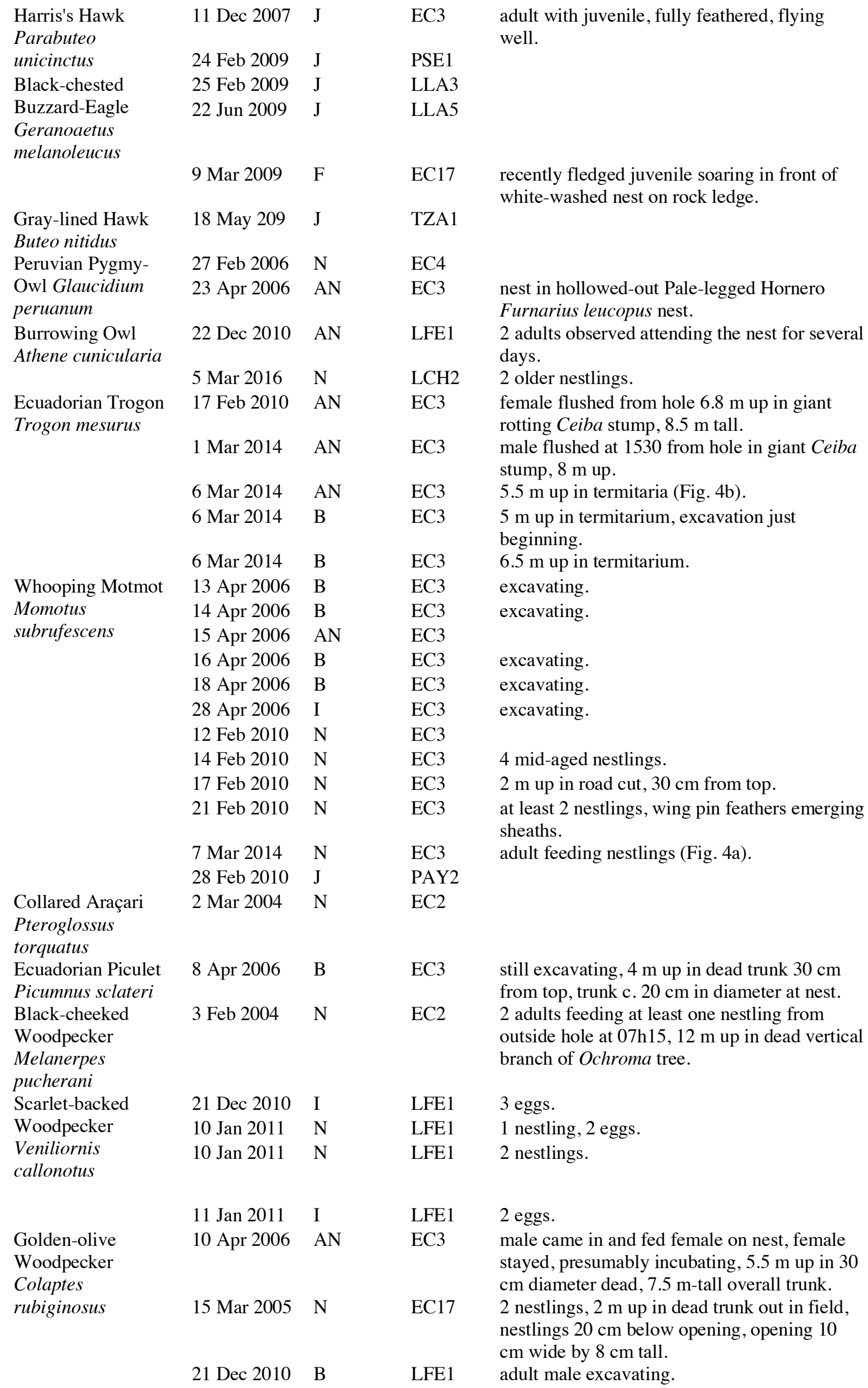




\begin{tabular}{|c|c|c|c|c|}
\hline & 16 Jan 2011 & I & LFE1 & $\begin{array}{l}1 \text { adult sitting long periods in nest, possibly } \\
\text { incubating. }\end{array}$ \\
\hline & 2 Jan 2016 & $\mathrm{~B}$ & LFE1 & adults excavating (Fig. 4c). \\
\hline Crested Caracara & 28 Feb 2009 & $\mathrm{CM}$ & PSE4 & adult carrying material. \\
\hline \multirow[t]{2}{*}{ Caracara cheriway } & 6 Mar 2009 & $\mathrm{~J}$ & PAY3 & juvenile accompanied by an adult. \\
\hline & 5 Mar 2011 & $\mathrm{~N}$ & PSE5 & at least one older nestling. \\
\hline \multirow[t]{2}{*}{$\begin{array}{l}\text { Bat Falcon Falco } \\
\text { rufigularis }\end{array}$} & 10 Mar 2010 & $\mathrm{~J}$ & PMO8 & $\begin{array}{l}\text { fledgling, perched } 12 \mathrm{~m} \text { up in Ceiba } \\
\text { trichistandra tree, begging and being fed by } \\
\text { adults. }\end{array}$ \\
\hline & 26 Feb 2014 & $\mathrm{AN}$ & EC3 & $12 \mathrm{~m}$ up in giant Ceiba stump. \\
\hline $\begin{array}{l}\text { Canary-winged } \\
\text { Parakeet Brotogeris } \\
\text { versicolurus }\end{array}$ & 21 Jan 2015 & AN & EC19 & $\begin{array}{l}\text { adult entering termite nest, c. } 2.5 \mathrm{~m} \text { up, second } \\
\text { adult singing } 5 \mathrm{~m} \text { away. }\end{array}$ \\
\hline Gray-cheeked & 10 Aug 2008 & $\mathrm{AN}$ & TTU5 & \\
\hline Parakeet & 16 Dec 2009 & $\mathrm{~J}$ & PSU1 & \\
\hline \multirow[t]{5}{*}{ B. pyrrhoptera } & 28 Jun 2010 & $\mathrm{AN}$ & TTU6 & \\
\hline & 27 Feb 2014 & $\mathrm{AN}$ & EC3 & $5 \mathrm{~m}$ up in termitarium (Fig. $5 \mathrm{~b})$ \\
\hline & 28 Feb 2014 & $\mathrm{AN}$ & EC3 & $6.5 \mathrm{~m}$ up in termitarium (Fig. 5a). \\
\hline & 27 Feb 2014 & AN & EC3 & $12 \mathrm{~m}$ up in natural hole in Ceiba tree (Fig. 5c). \\
\hline & 27 Feb 2014 & $\mathrm{AN}$ & EC3 & $16 \mathrm{~m}$ up in natural hole in Ceiba. \\
\hline \multirow{6}{*}{$\begin{array}{l}\text { Rose-faced Parrot } \\
\text { Pyrilia pulchra } \\
\text { Pacific Parrotlet } \\
\text { Forpus coelestis }\end{array}$} & 25 Feb 2014 & $\mathrm{~F}$ & $\mathrm{EC} 2$ & adults feeding begging fledgling. \\
\hline & 24 Feb 2006 & B & $\mathrm{EC} 1$ & adult excavating. \\
\hline & 9 Jun 2009 & $\mathrm{~J}$ & PHU2 & \\
\hline & $\begin{array}{l}\text { Late-Dec } \\
2010\end{array}$ & AN & LFE1 & $\begin{array}{l}2 \text { adults entering and exiting abandoned } \\
\text { woodpecker hole. }\end{array}$ \\
\hline & $\begin{array}{l}\text { Mid-Jan } \\
2011\end{array}$ & $\mathrm{AN}$ & LFE1 & $\begin{array}{l}2 \text { adults entering and exiting abandoned } \\
\text { woodpecker hole. }\end{array}$ \\
\hline & 16 Apr 2011 & $\mathrm{~N}$ & E18 & $\begin{array}{l}\text { inside an inclined Guadua bamboo pole, } \\
\text { entrance } 1.6 \mathrm{~m} \text { above ground. }\end{array}$ \\
\hline \multirow{5}{*}{$\begin{array}{l}\text { Red-masked } \\
\text { Parakeet Psittacara } \\
\text { erythrogenys } \\
\text { Great Antshrike } \\
\text { Taraba major }\end{array}$} & 22 Jun 2005 & $\mathrm{~J}$ & PHU3 & $\begin{array}{l}2 \text { fledglings taken from the nest by local } \\
\text { residents. }\end{array}$ \\
\hline & 14 Jun 2009 & $\mathrm{~J}$ & PMO9 & \\
\hline & 16 Apr 2006 & $\mathbf{J}$ & EC3 & $\begin{array}{l}\text { not fully independent juvenile foraging } \\
\text { independently near adults. }\end{array}$ \\
\hline & 30 Apr 2006 & $\mathrm{~J}$ & EC3 & $\begin{array}{l}\text { not fully independent juvenile foraging alone } \\
\text { in underbrush. }\end{array}$ \\
\hline & 13 Feb 2010 & $\mathrm{~N}$ & EC3 & \\
\hline \multirow[t]{7}{*}{$\begin{array}{l}\text { Collared Antshrike } \\
\text { Thamnophilus } \\
\text { bernardi }\end{array}$} & 18 Apr 2006 & $\mathrm{CF}$ & EC3 & $\begin{array}{l}\text { adult carrying food, alarm calling in response } \\
\text { to observer presence, active nest suspected, } \\
\text { possibly fledgling. }\end{array}$ \\
\hline & 10 Feb 2010 & $\mathrm{CM}$ & EC3 & $\begin{array}{l}\text { male and female carrying leaves and thin } \\
\text { fibers. }\end{array}$ \\
\hline & 17 Feb 2010 & $\mathrm{~B}$ & EC3 & \\
\hline & 6 Mar 2014 & $\mathrm{~B}$ & EC3 & $\begin{array}{l}\text { male fed female as she carried material to a } \\
\text { nearly completed nest, } 1.6 \mathrm{~m} \text { up. }\end{array}$ \\
\hline & 2 Mar 2014 & $\mathrm{~B}$ & EC3 & nest nearly complete (Fig. 6b). \\
\hline & 25 Feb 2010 & $\mathrm{~B}$ & EC3 & nest nearly complete. \\
\hline & 6 Mar 2010 & I & EC3 & 3 eggs. \\
\hline \multirow{3}{*}{$\begin{array}{l}\text { Black-crowned } \\
\text { Antshrike } \\
\text { T. atrinucha }\end{array}$} & 4 Feb 2004 & $\mathrm{I}$ & $\mathrm{EC} 2$ & 2 eggs (Fig. 6c). \\
\hline & 15 Feb 2004 & $\mathrm{~B}$ & $\mathrm{EC} 2$ & construction just beginning. \\
\hline & 22 Feb 2004 & $\mathrm{~B}$ & EC2 & adult with nesting material. \\
\hline $\begin{array}{l}\text { Uniform Antshrike } \\
\text { T. unicolor }\end{array}$ & 23 Feb 2000 & $\mathrm{~N}$ & EC14 & $\begin{array}{l}2 \text { adults at nest with } 2 \text { nestlings (pin feathers } \\
\text { broken } 2 \mathrm{~mm} \text { ). Nest open cup of small vines, } \\
\text { moss; } c .2 \mathrm{~m} \text { up in sapling. }\end{array}$ \\
\hline Plain Antvireo & 10 Feb 2010 & $\mathrm{I}$ & EC3 & 2 eggs. \\
\hline $\begin{array}{l}\text { Dysithamnus } \\
\text { mentalis }\end{array}$ & 19 Feb 2010 & $\mathrm{~B}$ & EC3 & 2 eggs eventually (Fig. 6a). \\
\hline
\end{tabular}




\begin{tabular}{|c|c|c|c|c|}
\hline Chestnut-backed & 13 Feb 2004 & $\mathrm{~N}$ & $\mathrm{EC} 2$ & 1 nestling. \\
\hline Poliocrania exsul & & & & \\
\hline $\begin{array}{l}\text { Chestnut-crowned } \\
\text { Antpitta Grallaria } \\
\text { ruficapilla }\end{array}$ & 1 Mar 2005 & I & EC17 & $\begin{array}{l}2 \text { eggs, date and nest measurements in } \\
\text { Greeney (2018). }\end{array}$ \\
\hline \multirow{2}{*}{$\begin{array}{l}\text { Watkins's Antpitta } \\
\text { G. watkinsi }\end{array}$} & 6 Mar 2014 & $\mathrm{~B}$ & EC3 & see text. \\
\hline & 4 Apr 2014 & $\mathrm{~N}$ & EC3 & see text. \\
\hline $\begin{array}{l}\text { Coastal Miner } \\
\text { Geositta peruviana }\end{array}$ & 24 Jan 2011 & $\mathrm{~N}$ & LFE1 & $\begin{array}{l}\text { at least } 2 \text { nestlings and one adult delivering } \\
\text { food, behavior two weeks earlier suggested } \\
\text { incubation. }\end{array}$ \\
\hline $\begin{array}{l}\text { Olivaceous } \\
\text { Woodcreeper }\end{array}$ & 23 Apr 2006 & $\mathrm{~F}$ & EC3 & $\begin{array}{l}\text { juvenile foraging with adults, occasionally } \\
\text { being fed. }\end{array}$ \\
\hline $\begin{array}{l}\text { Sittasomus } \\
\text { griseicapillus }\end{array}$ & & & & \\
\hline $\begin{array}{l}\text { Wedge-billed } \\
\text { Woodcreeper } \\
\text { Glyphorynchus } \\
\text { spirurus }\end{array}$ & 1 Mar 2004 & $\mathrm{~F}$ & EC2 & fledgling following adults. \\
\hline Red-billed & 25 Feb 2006 & $\mathrm{CM}$ & $\mathrm{EC} 1$ & Adult carrying material (bark strip). \\
\hline Scythebill & 13 Feb 2010 & I & EC3 & \\
\hline $\begin{array}{l}\text { Campylorhamphus } \\
\text { trochilirostris }\end{array}$ & 15 Feb 2010 & $\mathrm{~N}$ & EC3 & \\
\hline Streak-headed & 31 Jan 2004 & I & $\mathrm{EC} 2$ & \\
\hline Woodcreeper & 14 Feb 2004 & $\mathrm{~B}$ & $\mathrm{EC} 2$ & \\
\hline \multirow[t]{7}{*}{$\begin{array}{l}\text { Lepidocolaptes } \\
\text { souleyetii }\end{array}$} & 24 Feb 2006 & $\mathrm{~B}$ & $\mathrm{EC} 1$ & $\begin{array}{l}\text { both sexes carrying bark strips into gap cabin } \\
\text { wall, } 3 \mathrm{~m} \text { up. }\end{array}$ \\
\hline & 11 Apr 2006 & $\mathrm{~F}$ & EC3 & at least one fledgling being fed. \\
\hline & 12 Feb 2010 & B & EC3 & \\
\hline & 21 Dec 2010 & AN & LFE1 & inside abandoned $F$. leucopus nest. \\
\hline & 18 Mar 2012 & $\mathrm{~N}$ & LFE1 & three nestlings. \\
\hline & 25 Mar 2014 & $\mathrm{~B}$ & EC3 & $\begin{array}{l}4.8 \mathrm{~m} \text { up in natural cavity formed by } \\
\text { overlapping Ficus roots. }\end{array}$ \\
\hline & 2 Apr 2014 & $\mathrm{~B}$ & EC3 & $\begin{array}{l}0.6 \mathrm{~m} \text { up in natural cavity in living Ceiba tree } \\
\text { (Fig. 7a). }\end{array}$ \\
\hline Plain Xenops & 7 Feb 2004 & $\mathrm{~F}$ & EC2 & adults feeding fledgling. \\
\hline Xenops minutus & & & & \\
\hline Pale-legged & 2 Feb 2004 & $\mathrm{~B}$ & $\mathrm{EC} 2$ & \\
\hline Hornero Furnarius & 5 Feb 2004 & $\mathrm{~B}$ & $\mathrm{EC} 2$ & $9 \mathrm{~m}$ up, both adults building. \\
\hline \multirow[t]{15}{*}{ leисория } & 4 Dec 2003 & $\mathrm{~N}$ & EC6 & \\
\hline & 30 Mar 2006 & AN & EC6 & adult flushed from nest. \\
\hline & 30 Mar 2006 & I & EC6 & nest $4.5 \mathrm{~m}$ up in Acacia. \\
\hline & 3 Apr 2006 & $\mathrm{CM}$ & EC6 & adult carrying mud. \\
\hline & 24 Feb 2006 & $\mathrm{~N}$ & EC1 & \\
\hline & 24 Feb 2006 & $\mathrm{~B}$ & $\mathrm{EC} 1$ & \\
\hline & 25 Feb 2006 & I & EC1 & \\
\hline & 27 Feb 2006 & $\mathrm{CM}$ & EC4 & adult carrying material (straw). \\
\hline & 27 Feb 2006 & I & EC4 & \\
\hline & 8 Apr 2006 & B & EC3 & $\begin{array}{l}2 \text { adults building with mud mixed with small } \\
\text { fibers, } 3 \mathrm{~m} \text { up. }\end{array}$ \\
\hline & 10 Apr 2006 & B & EC3 & \\
\hline & 11 Apr 2006 & AN & EC3 & $5.5 \mathrm{~m}$ up in thorny tree. \\
\hline & 11 Apr 2006 & $\mathrm{~N}$ & EC3 & 2 nestlings, $3.5 \mathrm{~m}$ up in spiny tree. \\
\hline & 14 Apr 2006 & AN & EC3 & $\begin{array}{l}\text { adult sitting long periods, presumed incubation } \\
\text { or early nestling. }\end{array}$ \\
\hline & 11 Feb 2010 & $\mathrm{~B}$ & EC3 & $\begin{array}{l}\text { dome complete, entrance not well formed, } 8 \mathrm{~m} \\
\text { up. }\end{array}$ \\
\hline
\end{tabular}




\section{Buff-fronted}

Foliage-gleaner

Philydor rufum

Rufous-necked

Foliage-gleaner

Syndactyla

ruficollis

Henna-hooded

Foliage-gleaner

Clibanornis

erythrocephalus
11 Feb 2010

11 Feb $2010 \quad B$

13 Feb 2010 B

18 Feb $2010 \quad N$

21 Feb $2010 \quad$ N

11 Jan $2011 \quad$ B

11 Feb 2010 AN

11 Feb $2010 \quad$ B

18 Mar $2004 \quad$ N

17 Feb 2010 AN

5 Mar $2010 \quad$ AN

8 Apr 2006 AN

8 Apr 2006 B

8 Apr 2006 B

8 Apr 2006 AN

9 Apr 2006 AN

16 Apr 2006 I

20 Apr 2006 AN

21 Apr 2006 AN

22 Apr 2006 AN

18 Jan 2008 AN

10 Feb 2010 I

10 Feb 2010 AN

10 Feb 2010 AN

13 Feb $2010 \quad$ B

13 Feb 2010 AN

13 Feb 2010 AN

13 Feb 2010 AN

14 Feb 2010 B

14 Feb 2010 B

15 Feb 2010 AN

20 Feb 2010 AN

1 Mar 2014 AN

2 Mar 2014

3 Mar 2014 AN

4 Mar $2014 \quad$ AN

7 Mar 2014 AN

1 Mar 2014 AN

23 Feb 2000 AN

11 Apr 2006 CF

12 Feb 2007 AN

17 Mar 2005 I
EC3

EC3

EC3

EC3

EC3

LFE1

EC3

EC3

EC2

EC3

EC3

EC3

EC3

EC3

$\mathrm{EC} 3$

EC3

EC3

EC3

EC3

EC3

TTU6

EC3

EC3

EC3

EC3

EC3

EC3

EC3

EC3

EC3

EC3

$\mathrm{EC} 3$

EC3

EC3

EC3

EC3

EC3

EC3

EC3

EC14

EC5

EC20

EC17
2 adults building, just a cup so far, $5.5 \mathrm{~m}$ up in spiny tree.

2 adults bringing food, $18 \mathrm{~m}$ up in $30 \mathrm{~m}$-tall Ceiba sp.

3 nestlings ready to fledge, $3.6 \mathrm{~m}$ up.

building, $5.5 \mathrm{~m}$ up over road (Fig. 7c).

$6 \mathrm{~m}$ up near road.

adult arrives with material; remains inside for long periods, presumed incubation (Fig. 7e).

Fig. 7d.

for the following records of this species, those marked with $* * *$ had the details (but not date) published previously (Miller et al. 2012).

$* * *$

$* * *$

$* * *$

$* * *$

$* * *$

$* * *$

$* * *$

adult entering cavity.

$* * *$

$* * *$

$* * *$

$* * *$

$* * *$

$* * *$

$* * *$

$* * *$

$* * *$

$* * *$

$* * *$

$1.7 \mathrm{~m}$ up in $2 \mathrm{~m}$ bank, under $35 \mathrm{~cm}$ overhang, oriented $65^{\circ}$. Brood depredated by DryMaron sp. snake (Colubridae).

$2.5 \mathrm{~m}$ up in $2.8 \mathrm{~m}$ bank roadside, under $20 \mathrm{~cm}$ overhang, oriented $120^{\circ}$.

$1.8 \mathrm{~m}$ up in $2.4 \mathrm{~m}$ bank, under $45 \mathrm{~cm}$ overhang, oriented $140^{\circ}$.

$1.4 \mathrm{~m}$ up in $1.6 \mathrm{~m}$ bank, under $40 \mathrm{~cm}$ overhang.

$1.4 \mathrm{~m}$ up in $1.6 \mathrm{~m}$ bank, under $20 \mathrm{~cm}$ overhang.

$1.6 \mathrm{~m}$ up in $1.9 \mathrm{~m}$ bank, under $30 \mathrm{~cm}$ overhang (Fig. 8).

$5.2 \mathrm{~m}$ up on $5.3 \mathrm{~m}$ bank, under $25 \mathrm{~cm}$ overhang.

see text.

see text.

see text.

Cranioleuca 


\begin{tabular}{|c|c|c|c|c|}
\hline & 12 Mar 2009 & I & EC17 & see text. \\
\hline Necklaced Spinetail & 24 Mar 2009 & $\mathrm{AN}$ & LLA4 & Fig. 9b. \\
\hline $\begin{array}{l}\text { Synallaxis } \\
\text { stictothorax }\end{array}$ & 21 Dec 2010 & $\mathrm{~B}$ & LFE1 & 3 adults bringing material to nest. \\
\hline $\begin{array}{l}\text { Slaty Spinetail } S \text {. } \\
\text { brachyura }\end{array}$ & 7 Feb 2004 & I & EC2 & $\begin{array}{l}60 \mathrm{~cm} \text { up, } 3 \text { fresh eggs: } 20.8 \times 16.1,22.3 \times \\
16.8,22.1 \times 16.2\end{array}$ \\
\hline Azara's Spinetail $S$. & 17 Apr 2006 & $\mathbf{J}$ & EC5 & adults with at least one fledgling. \\
\hline \multirow[t]{6}{*}{ azarae } & 17 Apr 2006 & $\mathrm{~J}$ & EC5 & adults with at least one fledgling. \\
\hline & 17 Apr 2006 & $\mathbf{J}$ & EC5 & adults with at least one fledgling. \\
\hline & 11 Mar 2005 & Laying & EC17 & $\begin{array}{l}\text { nest } 1.7 \mathrm{~m} \text { up, } 1 \text { very fresh, immaculate white } \\
\text { egg }(18.8 \text { x } 15.5 \mathrm{~mm}, 2.48 \mathrm{~g}) \text {, suspected } \\
\text { incomplete clutch. }\end{array}$ \\
\hline & 18 Mar 2005 & Laying & EC17 & $\begin{array}{l}\text { nest } 1.1 \mathrm{~m} \text { up, } 1 \text { very fresh, immaculate white } \\
\text { egg }(22.1 \text { x } 16.8 \mathrm{~mm}) \text {, suspected incomplete } \\
\text { clutch. }\end{array}$ \\
\hline & 17 Mar 2005 & $\mathrm{CM}$ & EC17 & $\begin{array}{l}\text { nest } 2.1 \mathrm{~m} \text { up, empty, adults nearby carrying } \\
\text { sticks. }\end{array}$ \\
\hline & 4 Mar 2009 & I & EC17 & $\begin{array}{l}\text { nest } 1.9 \mathrm{~m} \text { up, } 1 \text { egg, adult flushed, do not } \\
\text { know if clutch complete. }\end{array}$ \\
\hline \multirow{10}{*}{$\begin{array}{l}\text { Blackish-headed } \\
\text { Spinetail S. tithys }\end{array}$} & 9 Apr 2006 & I & EC3 & $1.5 \mathrm{~m}$ up in thick tangle of Barnadesia sp. \\
\hline & 12 Apr 2006 & $\mathrm{CM}$ & EC3 & $\begin{array}{l}\text { adult traveling through understory carrying a } \\
\text { long stick. }\end{array}$ \\
\hline & 24 Apr 2006 & $\mathrm{~F}$ & EC3 & older fledgling foraging with adults. \\
\hline & 11 Feb 2010 & $\mathrm{~B}$ & EC3 & $\begin{array}{l}\text { nest ball forming, but no entrance tunnel } \\
\text { formed. }\end{array}$ \\
\hline & 13 Feb 2010 & $\mathrm{AN}$ & EC3 & \\
\hline & 13 Feb 2010 & AN & EC3 & \\
\hline & 10 Mar 2010 & $\mathrm{~F}$ & PHU1 & \\
\hline & 10 Mar 2010 & $\mathrm{CM}$ & PHU1 & adult carrying small stick. \\
\hline & 10 Mar 2010 & $\mathrm{~N}$ & PHU1 & adults entering nests with food. \\
\hline & 28 Feb 2014 & $\mathrm{~B}$ & EC3 & $\begin{array}{l}5 \mathrm{~m} \text { up in tangle of vines and branches in } 7 \mathrm{~m} \\
\text { tall tree, adults adding material to all portions, } \\
\text { looks complete (Fig. } 9 \mathrm{a} \text { ). }\end{array}$ \\
\hline $\begin{array}{l}\text { Sooty-headed } \\
\text { Tyrannulet }\end{array}$ & 9 Feb 2004 & $\mathrm{~N}$ & $\mathrm{EC} 2$ & $\begin{array}{l}\text { at least two young nestlings, } 6 \mathrm{~m} \text { up in } \\
\text { horizontal fork with lots of moss. }\end{array}$ \\
\hline $\begin{array}{l}\text { Phyllomyias } \\
\text { griseiceps }\end{array}$ & 14 Feb 2004 & $\mathrm{~B}$ & $\mathrm{EC} 2$ & \\
\hline Pacific Elaenia & 9 Apr 2006 & B & EC3 & \\
\hline $\begin{array}{l}\text { Myiopagis } \\
\text { subplacens }\end{array}$ & 12 Apr 2006 & $\mathrm{~B}$ & EC3 & \\
\hline Yellow-bellied & 2 Feb 2004 & $\mathrm{~B}$ & $\mathrm{EC} 2$ & \\
\hline \multirow[t]{2}{*}{$\begin{array}{l}\text { Elaenia Elaenia } \\
\text { flavogaster }\end{array}$} & 29 Feb 2004 & $\mathrm{CM}$ & $\mathrm{EC} 2$ & adult carrying moss. \\
\hline & 16 Dec 2013 & B & $\mathrm{EC} 21$ & $\begin{array}{l}\text { adult moving nesting materials from an old } \\
\text { nest to a new one. }\end{array}$ \\
\hline \multirow{7}{*}{$\begin{array}{l}\text { Southern Beardless- } \\
\text { Tyrannulet } \\
\text { Camptostoma } \\
\text { obsoletum }\end{array}$} & 24 Feb 2006 & B & EC1 & \\
\hline & 24 Feb 2006 & I & $\mathrm{EC} 1$ & \\
\hline & 25 Feb 2006 & $\mathrm{~B}$ & EC1 & \\
\hline & 25 Feb 2006 & I & EC1 & \\
\hline & 28 Feb 2009 & $\mathrm{CM}$ & PSE3 & adult carrying material. \\
\hline & $\begin{array}{l}15 \text { May } \\
2009\end{array}$ & $\mathrm{~F}$ & TTU1 & \\
\hline & 13 Feb 2010 & $\mathrm{AN}$ & EC3 & Fig. 10a. \\
\hline $\begin{array}{l}\text { White-banded } \\
\text { Tyrannulet }\end{array}$ & 29 Apr 2006 & $\mathrm{~F}$ & EC5 & adult followed by two fledglings. \\
\hline
\end{tabular}




\begin{tabular}{|c|c|c|c|c|}
\hline \multicolumn{5}{|l|}{$\begin{array}{l}\text { Mecocerculus } \\
\text { stictopterus }\end{array}$} \\
\hline \multicolumn{5}{|l|}{$\begin{array}{l}\text { Capsiempis } \\
\text { flaveola }\end{array}$} \\
\hline \multicolumn{5}{|l|}{$\begin{array}{l}\text { Euscarthmus } \\
\text { meloryphus }\end{array}$} \\
\hline Gray-and-white & 24 Mar 2009 & $\mathrm{I}$ & LLA3 & \\
\hline $\begin{array}{l}\text { Tyrannulet } \\
\text { Pseudelaenia } \\
\text { leucospodia }\end{array}$ & 24 Mar 2009 & $\mathrm{~N}$ & LLA3 & \\
\hline Olive-striped & 1 Feb 2004 & $\mathrm{I}$ & $\mathrm{EC} 2$ & \\
\hline $\begin{array}{l}\text { Flycatcher } \\
\text { Mionectes } \\
\text { olivaceus }\end{array}$ & 2 Feb 2004 & $\mathrm{~N}$ & $\mathrm{EC} 2$ & \\
\hline Ochre-bellied & 31 Jan 2004 & I & $\mathrm{EC} 2$ & \\
\hline \multirow[t]{2}{*}{$\begin{array}{l}\text { Flycatcher } M . \\
\text { oleagineus }\end{array}$} & 31 Jan 2004 & $\mathrm{~N}$ & $\mathrm{EC} 2$ & Fig. 10c. \\
\hline & $\begin{array}{l}1 \text { Feb } 2004 \\
1 \text { Feb } 2004\end{array}$ & $\begin{array}{l}\mathrm{N} \\
\mathrm{N}\end{array}$ & $\begin{array}{l}\mathrm{EC} 2 \\
\mathrm{EC} 2\end{array}$ & \\
\hline $\begin{array}{l}\text { Slaty-capped } \\
\text { Flycatcher } \\
\text { Leptopogon } \\
\text { superciliaris }\end{array}$ & 17 Mar 2004 & B & $\mathrm{EC} 2$ & construction just beginning. \\
\hline $\begin{array}{l}\text { Rufous-crowned } \\
\text { Tody-Flycatcher } \\
\text { Poecilotriccus } \\
\text { ruficeps }\end{array}$ & 26 Feb 2009 & I & $\mathrm{EC} 17$ & $\begin{array}{l}2 \text { eggs, } 1.9 \mathrm{~m} \text { up, hanging from drooping tip of } \\
\text { Chusquea bamboo shoot. }\end{array}$ \\
\hline Common Tody- & 2 Feb 2004 & $\mathrm{~B}$ & $\mathrm{EC} 2$ & \\
\hline Flycatcher & 10 Feb 2004 & $\mathrm{~B}$ & $\mathrm{EC} 2$ & \\
\hline $\begin{array}{l}\text { Todirostrum } \\
\text { cinereum }\end{array}$ & 13 Feb 2010 & $\mathrm{~B}$ & EC3 & $\begin{array}{l}5 \mathrm{~m} \text { up, at least one adult building, other } \\
\text { nearby, no wasp nest nearby. }\end{array}$ \\
\hline \multirow[t]{15}{*}{$\begin{array}{l}\text { Yellow-olive } \\
\text { Flatbill Tolmomyias } \\
\text { sulphurescens }\end{array}$} & 24 Feb 2006 & $\mathrm{I}$ & $\mathrm{EC} 1$ & $\begin{array}{l}3 \mathrm{~m} \text { up, } 1.2 \mathrm{~m} \text { from active wasp nest } \\
\text { (Vespidae) }(\text { Fig. } 10 \mathrm{~d}), 3 \text { eggs }(23.0 \times 9.4,22.0 \\
\times 9.1,21.9 \times 9.4 \mathrm{~mm})\end{array}$ \\
\hline & 7 Apr 2006 & $\mathrm{~N}$ & EC3 & $\begin{array}{l}3.5 \mathrm{~m} \text { up, fledged at least two nestlings on } 9 \\
\text { Apr. }\end{array}$ \\
\hline & 12 Apr 2006 & $\mathrm{~B}$ & EC3 & $\begin{array}{l}15 \mathrm{~m} \text { up in lower, outer branches of a large } \\
\text { Ceiba tree, } 1.5 \mathrm{~m} \text { from active wasp nest } \\
\text { (Vespidae). }\end{array}$ \\
\hline & 14 Apr 2006 & $\mathrm{~F}$ & EC3 & fledgling following adults. \\
\hline & 14 Apr 2006 & $\mathrm{~F}$ & EC3 & fledgling following adults. \\
\hline & 14 Apr 2006 & $\mathrm{~N}$ & EC3 & two adults bringing food into nest. \\
\hline & 16 Apr 2006 & $\mathrm{~F}$ & EC3 & fledgling following adults. \\
\hline & 11 Feb 2010 & B & EC3 & construction just beginning. \\
\hline & 13 Feb 2010 & AN & EC3 & $\begin{array}{l}20 \mathrm{~m} \text { up in } 35 \mathrm{~m} \text { Ceiba tree, } 2.5 \mathrm{~m} \text { from active } \\
\text { wasp nest (Vespidae). }\end{array}$ \\
\hline & 13 Feb 2010 & AN & EC3 & \\
\hline & 14 Feb 2010 & $\mathrm{~N}$ & EC3 & $\begin{array}{l}5 \mathrm{~m} \text { up, } 30 \mathrm{~cm} \text { from active wasp nest } \\
\text { (Vespidae), both adults bringing food at } \\
09 \mathrm{~h} 45 .\end{array}$ \\
\hline & 15 Feb 2010 & $\mathrm{~N}$ & EC3 & $\begin{array}{l}10 \mathrm{~m} \text { up, } 2 \mathrm{~m} \text { from active wasp nest } \\
\text { (Vespidae). }\end{array}$ \\
\hline & 17 Feb 2010 & AN & EC3 & $14 \mathrm{~m}$ up, $30 \mathrm{~cm}$ from wasp nest (Vespidae). \\
\hline & 17 Feb 2010 & $\mathrm{~N}$ & EC3 & \\
\hline & 19 Feb 2010 & AN & EC3 & $\begin{array}{l}26 \mathrm{~m} \text { up in } 35 \mathrm{~m} \text { Ceiba tree, } 60 \mathrm{~cm} \text { from active } \\
\text { wasp nest (Vespidae). }\end{array}$ \\
\hline
\end{tabular}




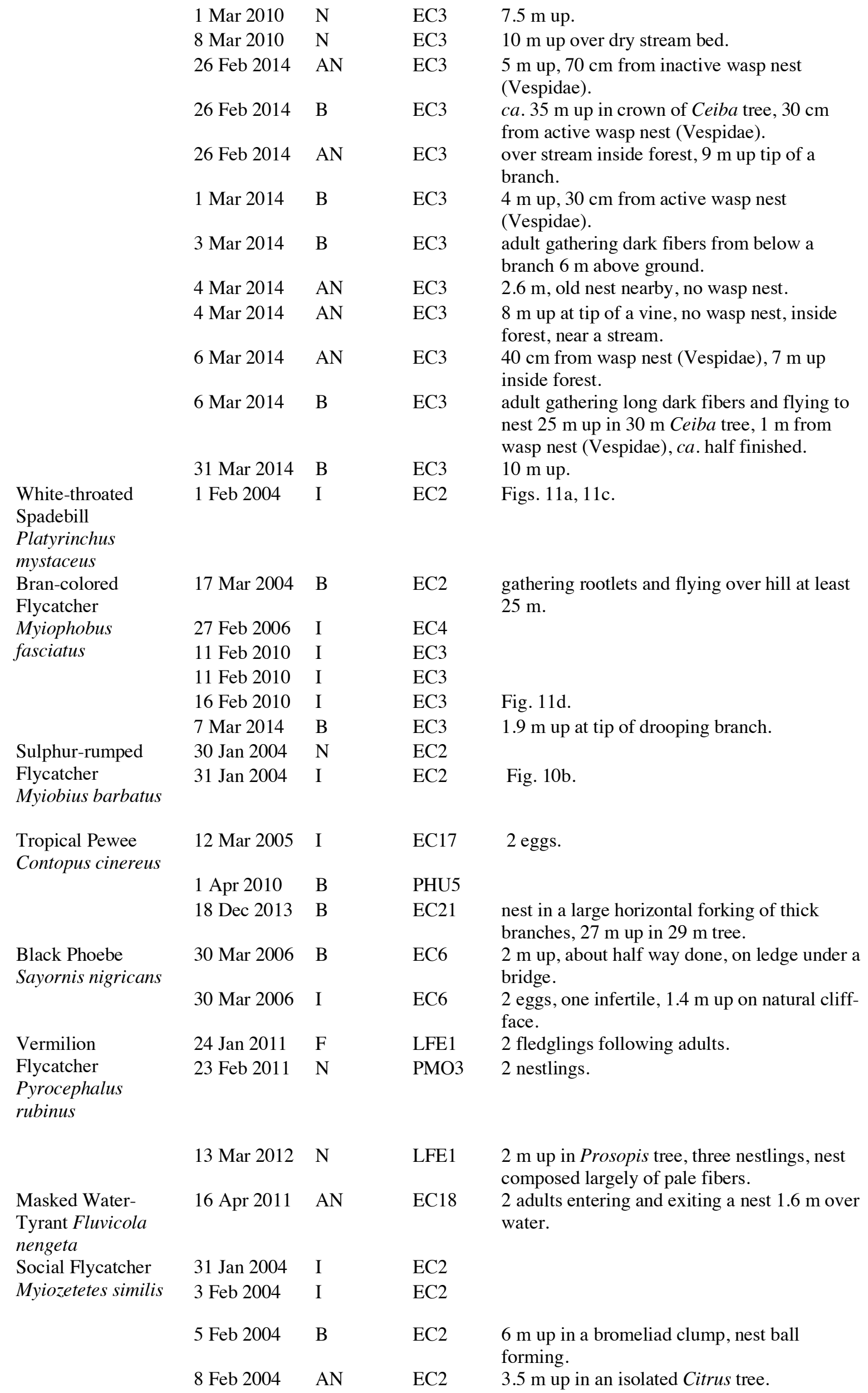




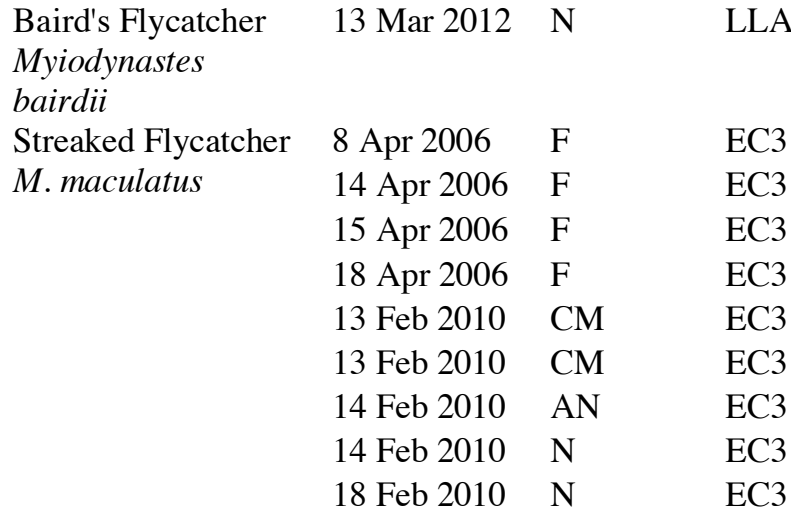

Boat-billed

Flycatcher

Megarynchus

pitangua

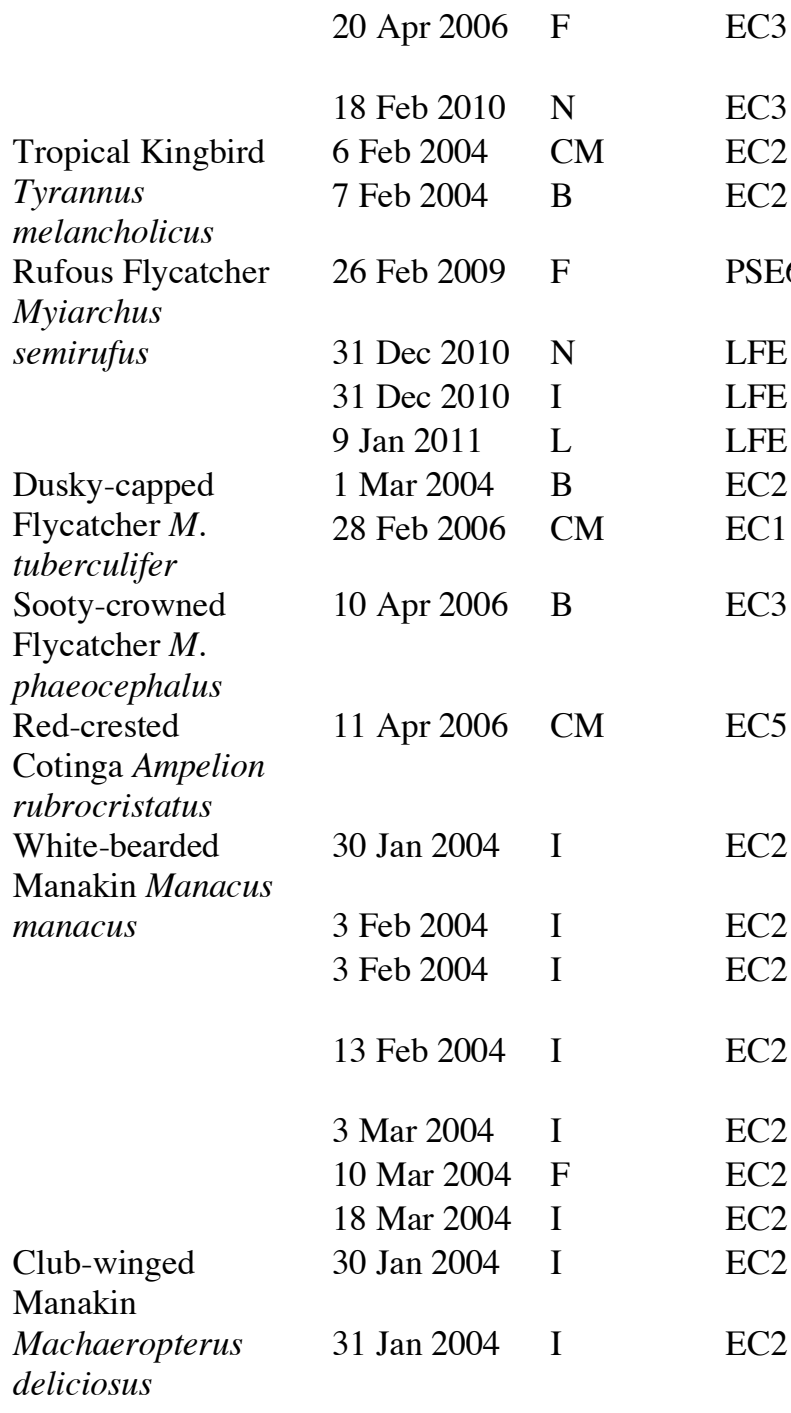

31 Jan 2004
$27 \mathrm{Feb} 2014 \quad$ AN $\quad$ EC3

7 Mar $2014 \quad$ B $\quad$ EC3

$14 \mathrm{Feb} 2004 \quad$ B $\quad$ EC2

$17 \mathrm{Feb} 2004 \quad \mathrm{CM} \quad \mathrm{EC} 2$
EC3 nest in a hole in a rock wall, both adults bring food (including lepidopteran larvae).

well-developed fledgling, still fed by adults. adult carrying material.

adult carrying material.

both adults provisioning, nest in abandoned $F$. leucopus nest, $16 \mathrm{~m}$ up, one adult feeding regularly but other spending a great deal of time chasing horneros from active nest $6 \mathrm{~m}$ away in same tree.

$20 \mathrm{~m}$ up at the broken end of a Ceiba branch.

$8 \mathrm{~m}$ up in old woodpecker cavity.

nest just beginning to form.

adult carrying material.

adult fed adult Papilio (Lepidoptera:

Papilionidae) to one of 2 fledglings.

both adults feeding nestlings, $15 \mathrm{~m}$ up.

adult carrying material.

$7 \mathrm{~m}$ up in crown of isolated tree.

PSE6 adult followed by begging fledgling (Fig.

11b).

LFE1 3 chicks, adults provisioning with insects.

LFE1 3 eggs in abandoned woodpecker cavity.

LFE1 3 eggs.

EC1 adult carrying material.

subsequently laid a clutch of two eggs.

adults regularly carrying material in same direction.

2 eggs $(23.1 \times 16.4,23.1 \times 15.9 \mathrm{~mm})($ Fig.

$12 \mathrm{a})$.

2 eggs, first egg laid $3 \mathrm{Feb}(24.2 \times 15.6 \mathrm{~mm})$.

2 eggs $(22.7 \times 15.4,22.6 \times 15.9 \mathrm{~mm})$ first laid

$3 \mathrm{Feb}$, second laid $5 \mathrm{Feb}$.

2 eggs, $20.6 \times 16.0 \mathrm{~mm}, 2.65 \mathrm{~g} ; 20.8 \times 15.7$ $\mathrm{mm}, 2.56 \mathrm{~g}$ ).

adult feeding fledgling.

2 eggs $(20.9 \times 15.4,22.0 \times 15.6 \mathrm{~mm})$.

2 eggs $(19.3 \times 14.4,19.9 \times 14.6 \mathrm{~mm})$, hatched

17 Feb, fledged 5 Mar.

2 eggs $(19.7 \times 13.9,20.8 \times 14.6 \mathrm{~mm})$, hatched

$14 \mathrm{Feb}$, both nestlings eaten, several hours after hatching, by Yellow-throated Toucan Ramphastos ambiguus.

EC2 2 eggs $(20.0 \times 14.3,20.9 \times 14.1 \mathrm{~mm})$. 


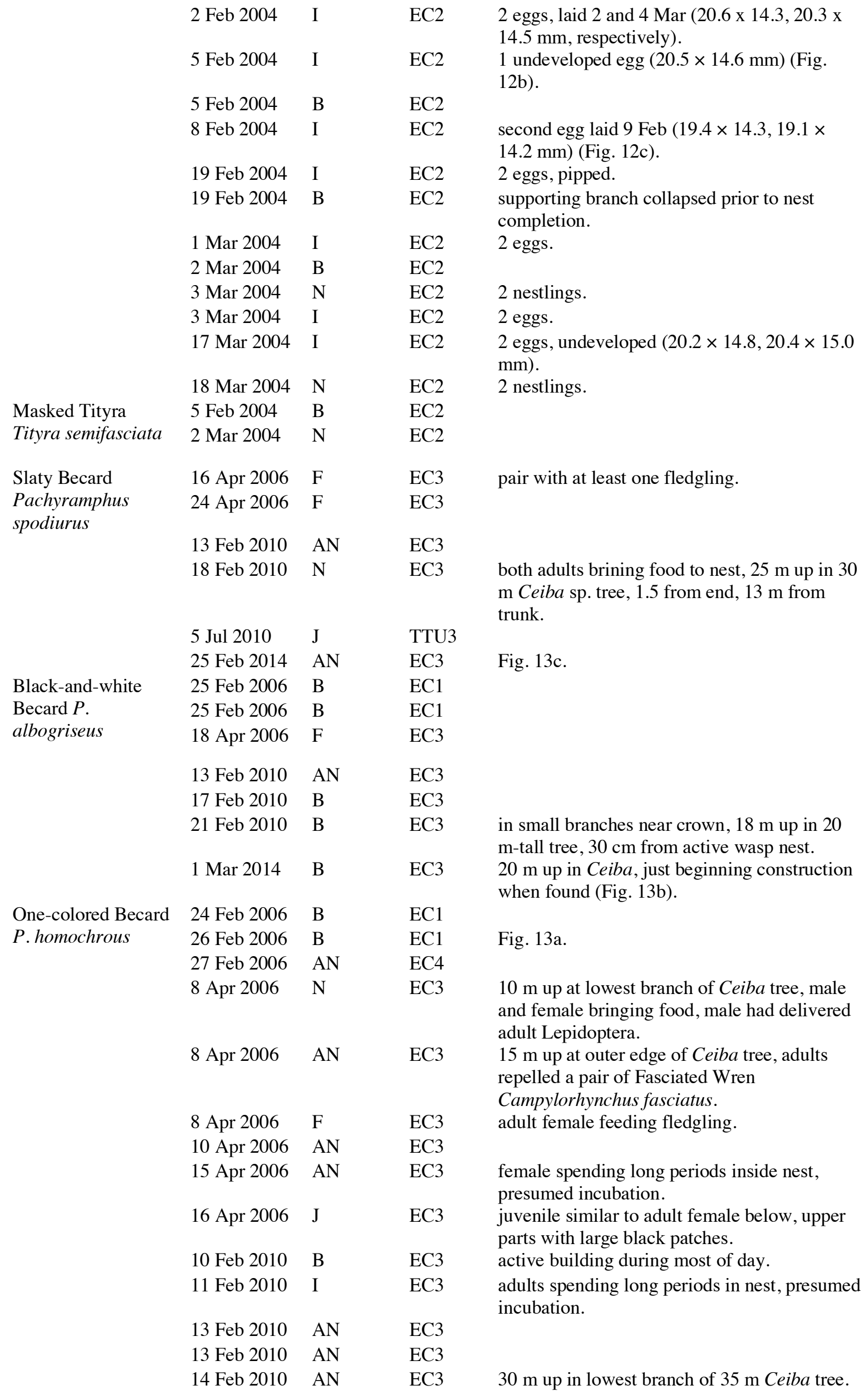




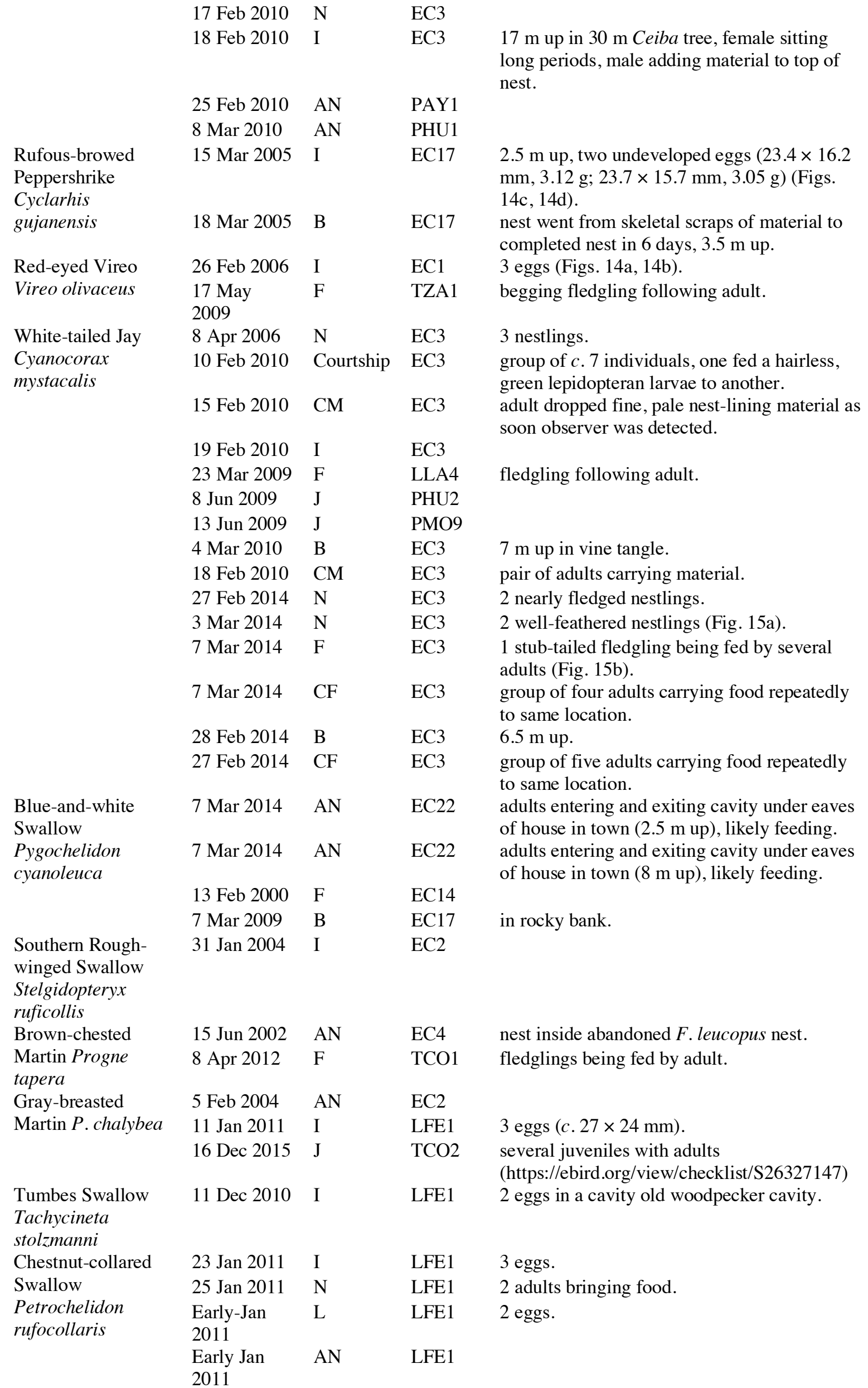




House Wren
Troglodytes aedon
Fasciated Wren
Campylorhynchus
fasciatus

30 Jan 2004 I

14 Feb 2004 B

24 Feb 2006 AN

10 Mar $2010 \quad \mathrm{~N}$

3 Mar $2014 \quad$ B

28 Mar 2014 I

5 Feb $2004 \quad$ B

17 Feb 2004 B

1 Mar 2004 B

11 Apr $2006 \mathrm{~N}$

21 Apr $2006 \mathrm{~N}$

28 Apr $2006 \mathrm{~N}$

11 Feb $2010 \quad \mathrm{~N}$

11 Feb 2010 B

18 Feb $2010 \quad \mathrm{~N}$

19 Feb $2010 \quad$ B

3 Feb $2011 \quad$ I

27 Mar 2014 I

10 Jun 2009 AN

4 Dec 2003 AN

9 Feb 2010 B

16 Feb $2010 \quad$ B

Speckle-breasted

Wren

Pheugopedius

sclateri

Bay Wren

Cantorchilus

nigricapillus

Gray-breasted

Wood-Wren

Henicorhina

leucophrys

LFE1 3 eggs.

LFE1 3 eggs.

PMO1 c.50 nests on an abandoned house.

EC4 many active nests at various stages.

EC14 c.115 active nests in various stages under bridge, at least some building some with nestlings.

EC2 Fig. 15d.

$\mathrm{EC} 2$

EC1

EC3

EC3

$1 \mathrm{~m}$ up in crevice in cabin wall, six nestlings, 5.5-6.5g.

same nest used in 2010 by L. souleyetii, $1 \mathrm{~m}$ up in crack-like cavity in living Ceiba tree trunk.

EC3 $15 \mathrm{~cm}$ down from broken top of bamboo post, four eggs (Fig. 15c).

$\mathrm{EC} 2$

$\mathrm{EC} 2$

adult carrying material to well-formed nest.

EC2

EC3

EC3

EC3

EC3

EC3

EC3

EC3

PSE2

EC3

PHU2

EC6

EC6

3 adults simultaneously brought food into nest.

$20 \mathrm{~m}$ up in $30 \mathrm{~m}$ Ceiba tree, at least three individuals bringing food.

2 adults building, $6.3 \mathrm{~m}$ up over road. adult captured with active incubation patch. 4 eggs (Fig. 15c).

Fig. 15b.

2 adults bringing feathers to nest in town park, $8 \mathrm{~m}$ up in small branches of $25 \mathrm{~m}$ tall tree near tip of branch.

EC3

2 Mar 2014 B EC3

6 Mar 2014 B EC3

7 Mar 2014 B EC3

7 Mar 2014 CM EC3

30 Jan 2004 I EC2

$3 \mathrm{Feb} 2004$ I $\quad$ EC2

24 Feb 2006 I $\quad$ EC1

26 Feb 2006 I EC1

28 Feb 2006 B EC1

31 May F PMO5

2010

4 Feb $2011 \quad \mathrm{~N}$

23 Feb 2000 I
PSE2

EC14 3 eggs.$$
3 \text { eggs. }
$$

$20 \mathrm{~cm}$ up in a branch tangle and overlapping sticks in dense undergrowth.

$10 \mathrm{~cm}$ up in a branch tangle. adult carrying material repeatedly into thicket. pair of adults carrying material.

Fig. 16a.

begging fledgling. 


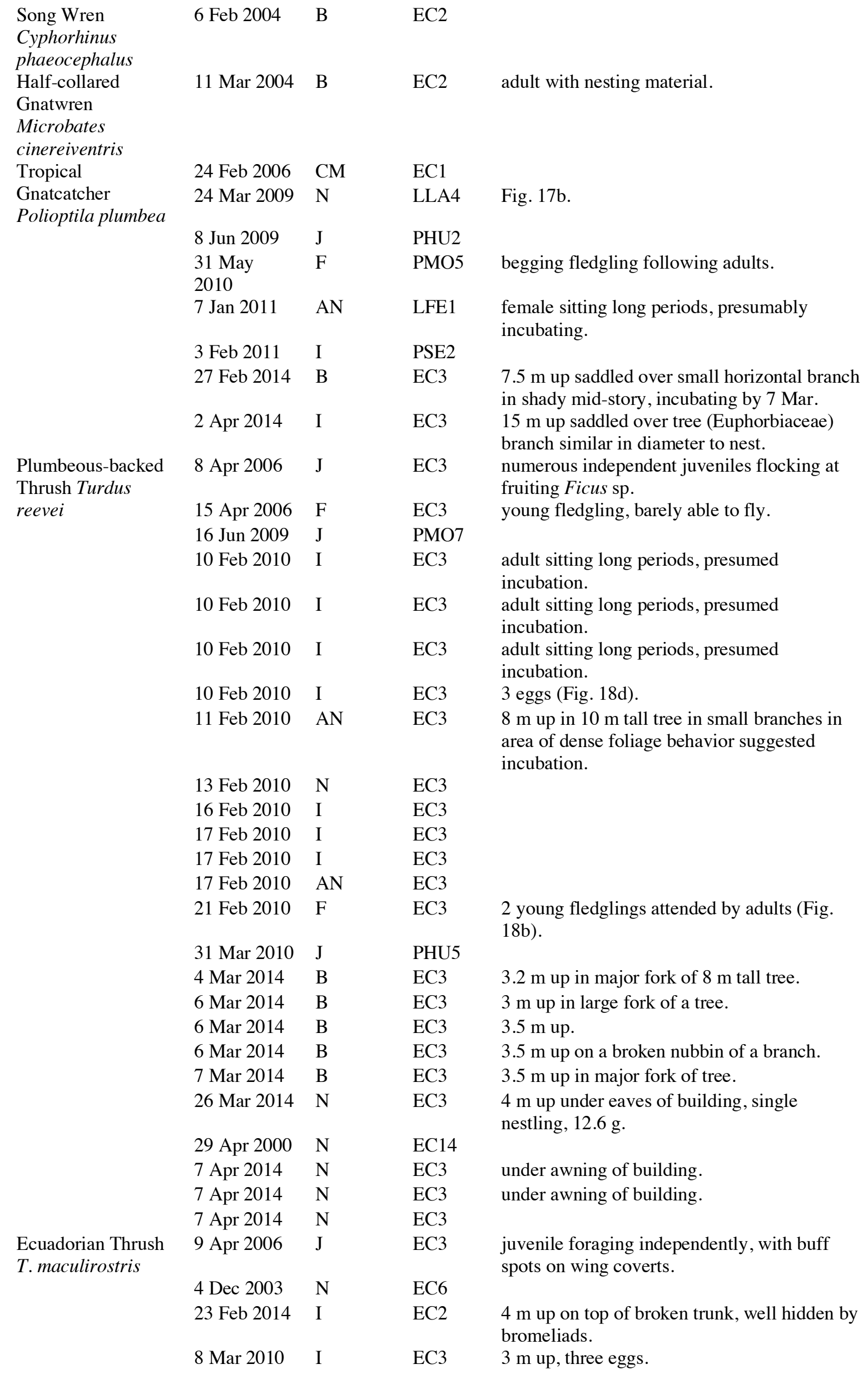


17 Jan 2011

EC1

Long-tailed

Mockingbird

Mimus

longicaudatus

House Sparrow
Passer domesticus
Thick-billed
Euphonia Euphonia
laniirostris

31 May
2010

22 Jan 2012

7 Mar 2014

7 Mar 2014

7 Mar 2014

7 Mar 2014

7 Mar 2014

AN

$\mathrm{EC} 1$

11 Feb 2010 I

13 Feb $2010 \quad N$

11 Feb $2010 \quad$ B

7 Mar $2014 \quad$ B

24 Mar $2009 \quad \mathrm{~N}$

12 Apr 2006 B

7 Mar 2014

7 Mar 2014 AN

8 Apr $2012 \quad \mathrm{~N}$

3 Feb 2004

3 Mar 2004

28 Feb 2006

8 Apr 2006

$\mathrm{CM}$

$\mathrm{F}$

12 May

2009

Orange-bellied

Euphonia $E$.

xanthogaster

Black-striped

Sparrow

Arremonops

conirostris

Orange-billed

Sparrow Arremon

aurantiirostris

Rufous-collared

Sparrow

Zonotrichia

capensis

White-headed

Brush-Finch
3 Feb 2004 I

15 Feb 2004 CM

27 Feb 2004 CM

3 Feb $2004 \quad$ CM

5 Feb $2004 \quad$ B

19 Feb 2004 I

15 Mar $2004 \quad$ B

26 Feb $2004 \quad F$

26 Feb $2004 \quad F$

8 Mar 2004 B

16 Mar $2004 \quad \mathrm{~N}$

24 Mar $2004 \quad F$

24 Jan $2016 \quad F$

18 Mar $2016 \quad F$

13 Mar 2012 Nest

LLA7

EC2

EC2

EC2

$\mathrm{EC} 2$

EC2

EC2

EC2

EC2

EC2

$\mathrm{EC} 2$

$\mathrm{EC} 2$

EC2

LCH1

LCH1
EC3

EC3

EC3

EC3

EC3

$\mathrm{EC} 2$

$\mathrm{EC} 2$

EC1

$\mathrm{EC} 3$
3 eggs $(28.7 \times 20.9 \mathrm{~mm}, 6.2 \mathrm{~g} ; 28.6 \times 21.1$ $\mathrm{mm}, 6.2 \mathrm{~g} ; 30.3 \times 21.1 \mathrm{~mm}, 6.4 \mathrm{~g}), 90 \mathrm{~cm}$ up, measurements: external diameter $14 \mathrm{~cm}$; external height $9 \mathrm{~cm}$; internal diameter $8 \mathrm{~cm}$; internal depth $5.5 \mathrm{~cm}$.

$5 \mathrm{~m}$ up.

3 eggs (Fig. 18e).

LLA4

at least one very young fledgling, just below nest, $2.3 \mathrm{~m}$ up in fork of $4.5 \mathrm{~m}$ sapling.

$8 \mathrm{~m}$ up in $15 \mathrm{~m}$ tall tree in thick fork.

Fig. 18a.

PMO5 begging fledgling.

LCH1 begging fledgling.

EC7 adult carrying long stick.

EC8 $0.5 \mathrm{~m}$ up in Acacia.

EC10 $\quad 3.5 \mathrm{~m}$ up in Acacia.

EC9 see text (Fig. 18c).

EC11 $1.5 \mathrm{~m}$ up in major fork near center of spiny Acacia tree, both adults near nest, one carrying stick.

EC12 adult sitting in nest.

EC13 $2.5 \mathrm{~m}$ up in Acacia.

TCO1 nest in crevice in a building.

TTU4

male fed fledgling two different types of crushed fruits.

male and female carrying moss.

male carrying material, female nearby.

in dense pasture grass, four sparrow eggs and two M. bonariensis eggs (Fig. 21d).

found with a single, freshly laid egg.

adult with nesting material

2 recently fledged young.

adults nearby with food, alarm calling.

fledglings can barely fly, feedings by adults observed.

fledgling following adult.

adult sparrow feeding fledgling $M$.

bonariensis.

nest behind a big bromeliad, at the base, well hidden. 


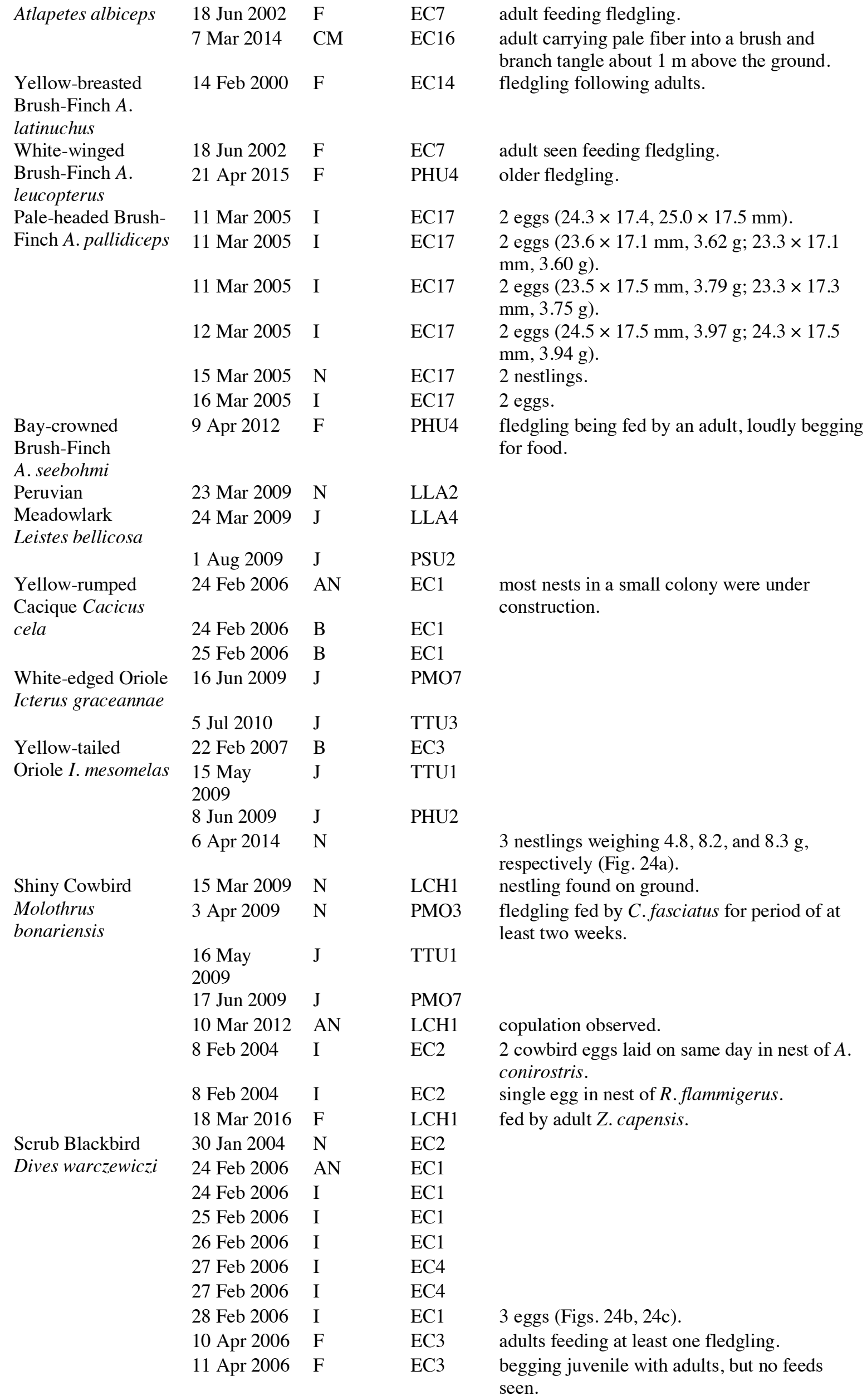


30 Mar $2006 \quad F$

30 Mar $2006 \quad F$

7 Mar 2014 CF

24 Feb 2014 AN

30 Mar 2006 CM

30 Mar 2006 B

4 Apr 2006

9 Feb 2010 I

11 Feb 2010 N

11 Feb 2010 AN

13 Feb 2010 AN

13 Feb 2010 I

Masked

Yellowthroat

Geothlypis

aequinoctialis

Tropical Parula

Setophaga

pitiayumi

Yellow Warbler $S$.

petechia

Gray-and-gold

Warbler

Myiothlypis fraseri

Three-banded

Warbler

Basileuterus

trifasciatus

Slate-throated

Redstart

Myioborus miniatus

Spectacled Redstart

M. melanocephalus

Hepatic Tanager

Piranga flava
9 Jun $2009 \quad \mathrm{~N}$

18 Mar $2005 \mathrm{~N}$

29 Feb 2004 AN

12 Apr 2006 B

24 Mar $2010 \quad J$

25 Feb 2009 CM

10 Feb 2010 I

10 Feb 2010 B

10 Feb $2010 \quad$ B

12 Feb 2010

12 Feb $2010 \quad N$

12 Feb $2010 \quad \mathrm{~N}$

14 Feb $2010 \quad$ B

16 Feb 2010 CM

18 Feb $2010 \quad \mathrm{~N}$

18 Feb $2010 \quad \mathrm{~N}$

28 Mar 2014 B

6 Mar 2014 B

3 Apr $2014 \quad \mathrm{~N}$

9 Apr $2012 \quad$ F

5 Feb 2004 B

EC2

28 Feb $2004 \quad$ CM

EC2

4 Mar 2005 AN

EC17

EC17

13 Mar 2005 B

1 Mar $2009 \quad F$

6 Mar $2009 \quad F$

6 Mar 2009 I

7 Mar 2009

19 May $\quad J$

2009

$\mathrm{EC} 2$

EC3

PSE1

EC3

EC3

EC3

EC3

EC3

EC3

EC3

EC3

EC3

EC3

$\mathrm{EC} 3$

EC3

EC3

PHU4
EC3 pair feeding stub-tailed fledgling.

EC6 pair feeding 2 spotty-breasted fledglings.

EC6

EC22 adult carrying food into the top of vine covered tree, $6 \mathrm{~m}$ up.

EC2

EC6

EC6

$\mathrm{EC} 23$

EC3

EC3

EC3

EC3

EC3

PHU2

EC17 3 newly-hatched nestlings (Fig. 23b).

$\mathrm{PMO} 2$

$6.3 \mathrm{~m}$ up in an Acacia sp. tree, $9 \mathrm{~m}$ from center of tree, 1.5 from end, tree $10 \mathrm{~m}$ tall, both adults feeding.

male following female and singing as she builds.

Fig. 23a.

2 eggs about half-way developed. ready to lay.

4 mid-aged nestlings (Fig. 22c). just starting to form ball. carrying material, female gathering fine dark fibers, male singing and following.

2 eggs laid by 3 Apr.

nest nearly complete (Figs. 22a, 22b).

2 older nestlings.

fledging being fed by an adult.

EC17 adult feeding older fledgling.

EC17 1 fledgling being fed by adult.

EC17 2 eggs, on ground in a bank cut.

EC17 nest on a steep bank, nearly finished. 


Golden Grosbeak
Pheucticus
chrysogaster


Tlame-rumped
Tanager
Ramphocelus
flammigerus
Green
Honeycreeper
Chlorophanes spiza
Saffron Finch
Sicalis flaveola
Phiterra-Finch
Piglosided

24 Feb $2006 \quad \mathrm{~N}$

$\mathrm{EC} 1$

25 Feb 2006 I EC1

8 Apr $2006 \mathrm{~N} \quad$ EC3

8 Apr $2006 \quad \mathrm{~F}$

9 Jun $2009 \quad$ F

11 Feb 2010 I

13 Feb $2010 \quad N$

13 Feb 2010 AN

31 Mar 2006 I

17 Mar 2005 B

1 Mar $2009 \quad$ F

27 Mar 2014 I

31 Mar 2014 I

6 Mar $2014 \quad$ B

3 Mar 2004 B

18 Feb 2004 CM

13 Feb 2004 B

16 Mar $2004 \quad F$

2 Apr $2006 \quad$ F

18 Mar $2012 \mathrm{~N}$

20 Mar $2012 \mathrm{~N}$

2 Dec $2015 \quad \mathrm{~F}$

21 Jan $2016 \quad F$

7 Jun $2009 \quad$ F

6 Aug $2010 \quad$ J

11 Apr 2006 CM

4 Feb 2004

4 Feb 2004 I

4 Feb 2004

4 Feb 2004

5 Feb 2004

7 Feb 2004

7 Feb 2004

7 Feb 2004

8 Feb 2004

10 Feb 2004

11 Feb 2004

14 Feb 2004

15 Feb 2004

17 Feb 2004

19 Feb 2004

EC3

EC3

EC3

EC3

EC6

EC3

EC3

EC3

EC2

EC2

EC2

$\mathrm{EC} 2$

EC6

EC5

EC2

EC2

EC2

EC2

EC2

$\mathrm{EC} 2$

EC2

EC2

$\mathrm{EC} 2$

EC2
PHU2

EC17

EC17

LFE1

LFE1

LCH1

$\mathrm{LCH} 1$

PMO3

PMO3

17 Mar $2004 \quad$ B

EC2

21 Oct 2009
2 eggs, estimated hatch 6 Feb.

2 eggs, hatched 8 Feb.

female carrying material.

female carrying material, male following (carrying piece of bark) at 07h45.

adult feed older fledgling.

$10 \mathrm{~m}$ up, at least one egg visible through bottom of nest. $\mathrm{mm}, 4.7 \mathrm{~g}$ ).

$3.8 \mathrm{~m}$ up saddled between two bromeliads on horizontal branch.

adult female carrying large dead leaf.

4 fledglings, no feed seen, but copious, loud begging.

4 young nestlings, 1 egg.

6 nestlings.

at least 4 juveniles seen.

at least 5 older fledglings traveling with two pairs of adults.

female carrying bill-full of light green moss.

2 tanager eggs, one of $M$. bonariensis, all hatched by 15 Feb (Fig. 19d).

female carrying material at $10 \mathrm{~h} 00$. female sitting on nest, contents not seen. female carrying material.

Fig. 19c.

nest taken by Swallow-tailed Kite E. forficatus that swooped down and hit nest, picked up whole nest, carried it up and away, extracted one nestling, other dropped to ground. 


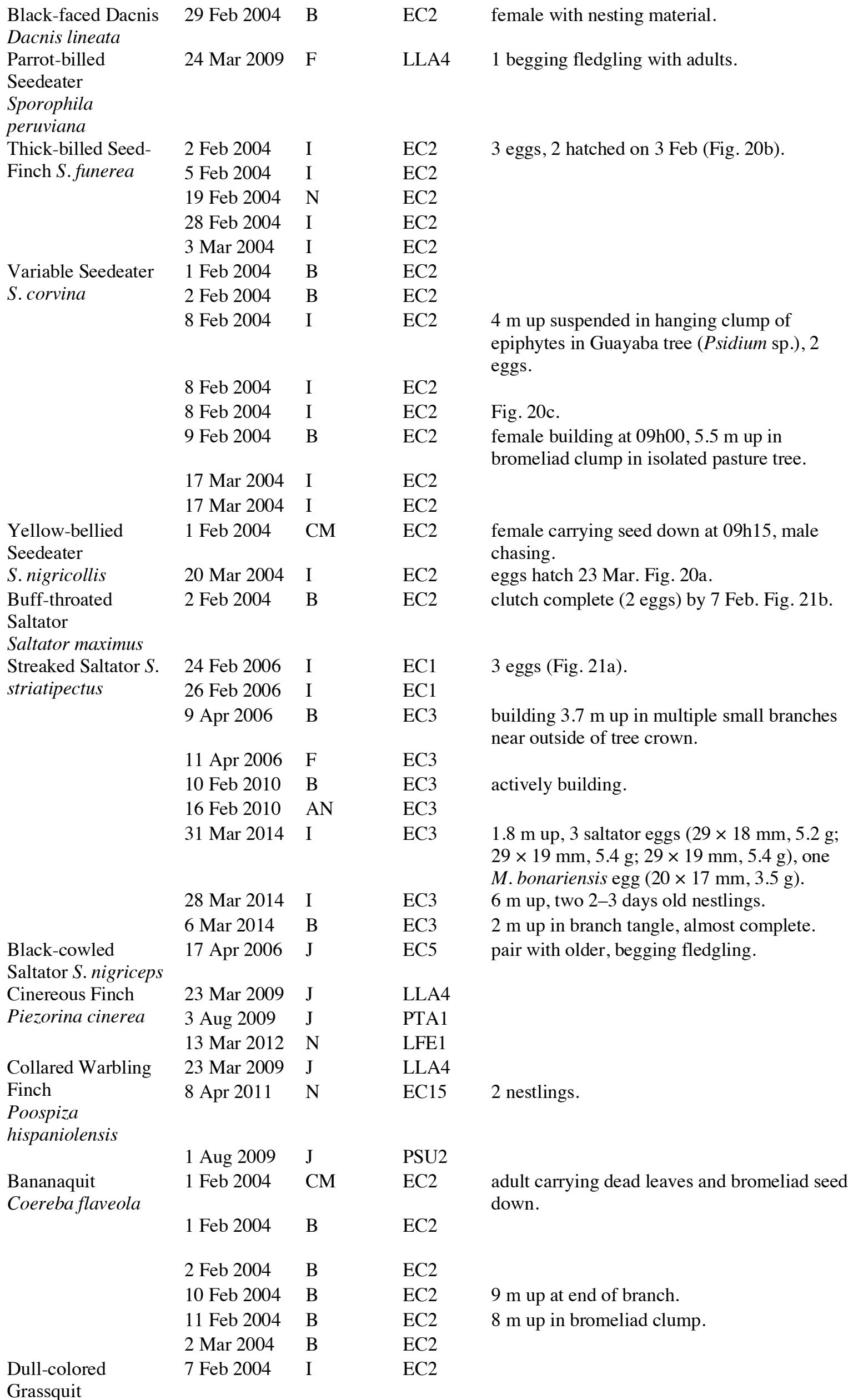




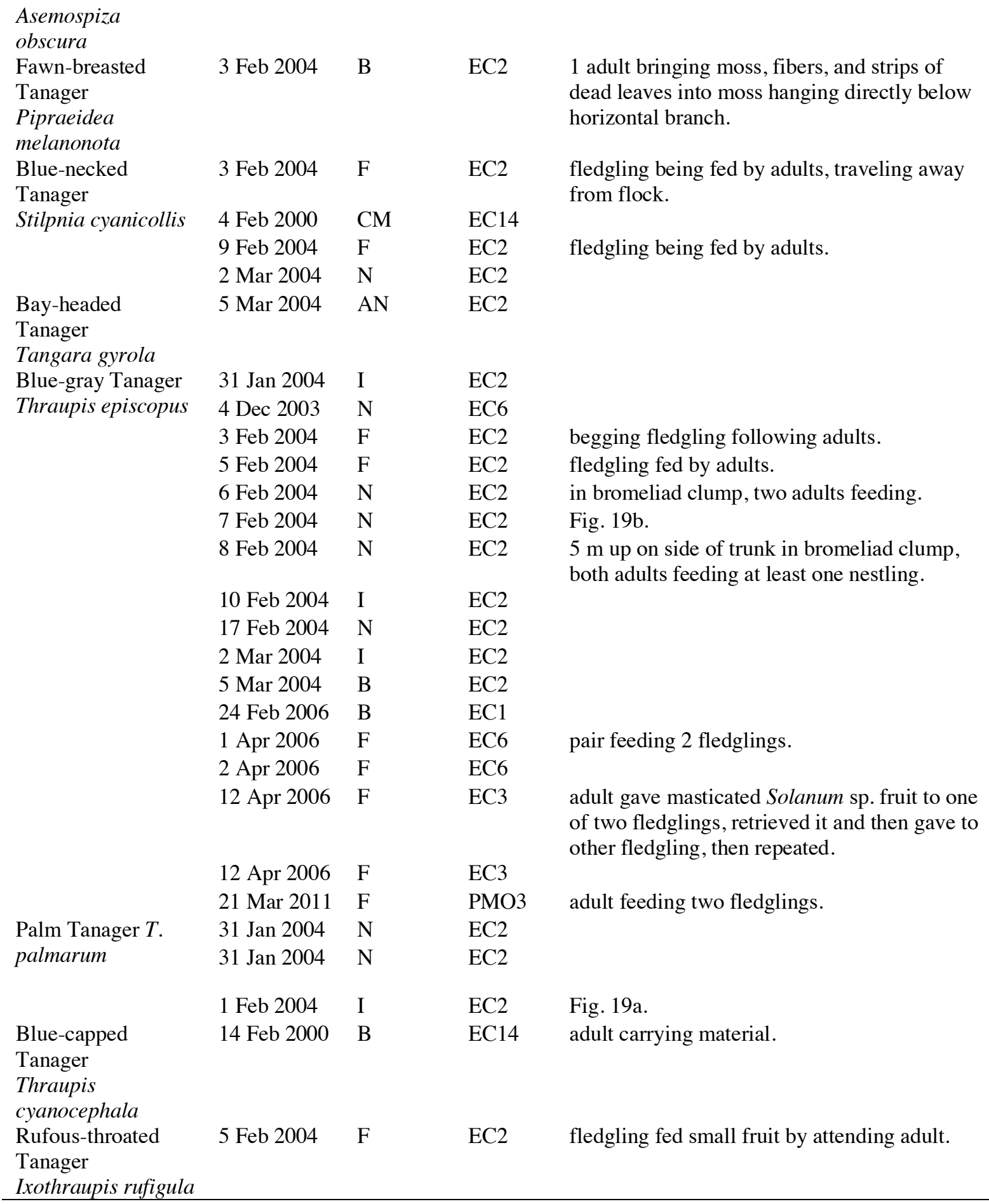

